\title{
VALOR ATRIBUÍDO PELA POPULAÇĀO ÀS MATAS CILIARES DA BACIA DO RIO CORUMBATAÍ, SP
}

\author{
CAETANO BRUGNARO
}

Engenheiro Agrônomo

Orientadora: PROFa DR ${ }^{a}$ ZILDA PAES DE BARROS MATTOS

Tese apresentada à Escola Superior de Agricultura "Luiz de Queiroz", da Universidade de São Paulo, para obtenção do título de Doutor em Ciências, Área de Concentração: Economia Aplicada.

PIRACICABA

Estado de São Paulo - Brasil

Agosto - 2000 
Dados Internacionais de Catalogaçāo na Publicaçāo (CIP)

DIVISĀO DE BIBLIOTECA E DOCUMENTAÇĀO - Campus "Luiz de Queiroz"IUSP

\author{
Brugnaro, Caetano. \\ Valor atribuido pela população às matas cıliares da Bacia do Rio Corumbatai, SP / \\ Caetano Brugnaro. - - Piracicaba, 2000. \\ 146 p. : il. \\ Tese (doutorado) - Escola Superior de Agricultura Luiz de Queiroz, 2000. \\ Bibliografia. \\ 1. Mata ciliar 2. Rio Corumbatai (Bacia) 3. Valonzação I. Título
}

"Permitida a cópia total ou parcial deste documento, desde que citada a fonte - 0 autor" 
ii.

A Jô, Camila e Paulo, DEDICO 


\section{AGRADECIMENTOS}

à Universidade Federal de São Carlos (UFSCar), que autorizou meu afastamento em alguns dias da semana para cumprir as obrigações do curso;

em especial, à Profa. Dra . Zilda Paes de Barros Mattos, minha orientadora, pela competência e pela perseverança com que insistiu em fazer produzir terreno tão pouco fértil;

aos professores Dr.Joaquim Bento de Souza Ferreira Filho, Dr.Ricardo Shirota e Dr.Rodolfo Hoffmann, pelas valiosas críticas e sugestões apresentadas em fases anteriores deste trabalho, e aos demais componentes do Departamento de Economia, Administração e Sociologia da ESALQ/USP;

a Ligiana e Luciene, bibliotecárias, e Maiele, secretária do curso, pela ajuda na solução de um sem-número de problemas cotidianos;

à brava equipe de colaboradores, alunos de graduação em Engenharia Agronômica da UFSCar, campus Araras, pela presteza, energia e coragem com que realizaram as entrevistas desta pesquisa; um abraço em Eduardo de Andrade Bressan, Gustavo Ricardo Gonçalves Becari, José Luís Franceschini, Juliana Cressoni Araújo, Karina Carnielli Zamprogno, Marcela Painceras Deaño, Marcelo Kviatkovski, Marcelo Menezes Caffer, Rafael Fernandes de Oliveira, Thaís de Paula Nobre e Thiago Guedes Penha Mena; e

ao Programa Institucional de Capacitação Docente e Técnica (PICDT) da Coordenação de Aperfeiçoamento de Pessoal de Nível Superior (CAPES), pela bolsa de $\mathrm{R} \$ 536,44$ mensais concedida a partir de março de 1997. 


\section{SUMÁRIO}

Página

LISTA DE FIGURAS ….......................................................... vi

LISTA DE TABELAS ............................................................... vii

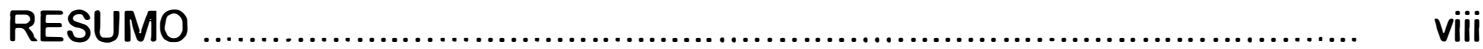

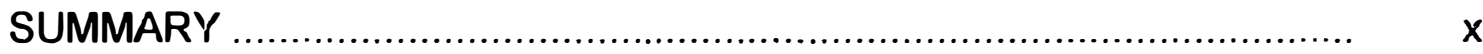

1 INTRODUÇĀO ................................................................. 1

1.10 problema e justificativa .................................................... 1

1.2 Papel das matas ciliares na qualidade ambiental ........................ 8

1.3 Aspectos legais do problema ................................................ 11

1.4 Aspectos econômicos do problema ......................................... 16

1.5 Objetivos deste trabalho ..................................................... 24

1.6 Procedimentos ................................................................... 25

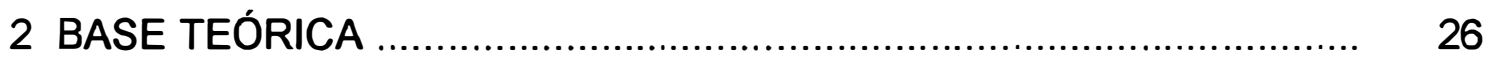

2.1 Disposição a pagar e disposição a aceitar compensação ................. 27

2.2 Diferenças entre disposição a pagar e a aceitar compensação ......... 35

2.3 Métodos de valoração ambiental .......................................... 37

2.3.1 Complementaridade fraca ................................................. 40

2.3.2 Valoração contingente ..................................................... 42

2.4. Discussão dos métodos de valoração contingente ............................ 49

2.4.1 Comportamento estratégico ............................................... 52

2.4.2 Concepção do mercado contingente ......................................... 53

2.4.3 Considerações adicionais ................................................... 59

2.5 Técnicas de levantamento ................................................... 60 


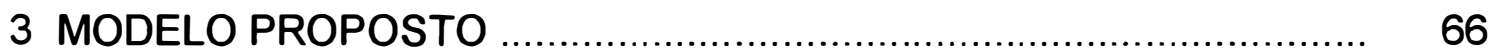

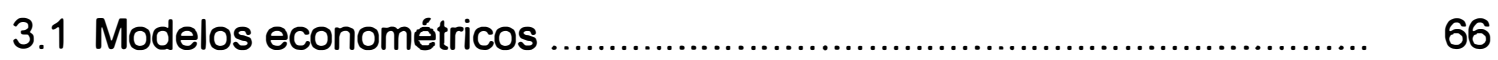

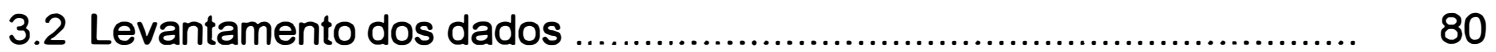

3.3 Caracterização da área de estudo ................................................ 81

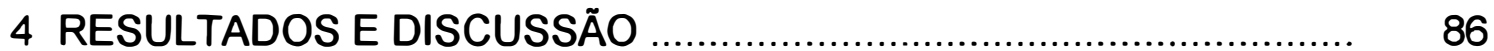

4.1 Condução da pesquisa de campo ................................................ 86

4.2 Resultados sem exclusão dos protestos ......................................... 88

4.2.1 Perfil da amostra ..................................................................... 88

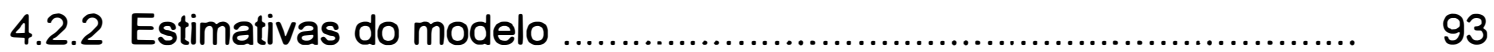

4.3 Resultados com exclusão dos protestos ......................................... 97

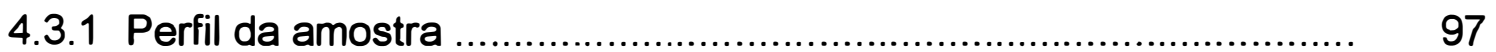

4.3.2 Estimativas do modelo ............................................................ 98

5 RESUMO, CONCLUSŌES E SUGESTÕES .................................... 101

REFERÊNCIAS BIBLIOGRÁFICAS ............................................ 112

APÊNDICE 1. Croqui de localização, abrangência e hidrografia da bacia do rio Corumbataí (sem escala) ........................... 133

APÊNDICE 2. Uso do solo na bacia do rio Corumbataí ........................... 134

APÊNDICE 3. Material de apoio e questionário para as entrevistas ....... 135

APÊNDICE 4. Das vicissitudes por que pode passar uma pesquisa ....... 140 


\section{LISTA DE FIGURAS}

Página

1 Evolução da cobertura com vegetação natural na DIRA de Campinas, 1972-95

2 Espaço político para qualidade ambiental

3 Variação equivalente (e) e variação compensatória $(c)$ da renda no caso de uma redução no preço de $x$

4 Demanda ordinária e demanda compensada

5 Disposição a pagar $(p)$ e disposição a aceitar compensação (a)

6 Representação de uma função de disposição a pagar 


\section{LISTA DE TABELAS}

1 Largura mínima da faixa com mata ciliar

2 Uso do solo nos municípios da bacia do Corumbataí, 1995-96 (em mil ha)

3 Demanda de água para consumo urbano e agropecuária, 1990 e $2000\left(\mathrm{~m}^{3} / \mathrm{s}\right)$

4 População residente nos municípios da bacia do rio Corumbataí, por local de domicílio e sexo, 1996

5 Número de domicílios particulares permanentes dos municípios que contêm a bacia do rio Corumbataí, 1996

6 Distribuição etária da população dos municípios que contêm a bacia do rio Corumbataí, 1996. Em percentagem

7 Anos de estudo do chefe do domicílio e taxas de analfabetismo de adultos nos municípios que contêm a bacia do rio Corumbataí, 1996

8 Níveis de renda dos chefes de domicílio dos municípios que contêm a bacia do rio Corumbataí, 1996. Em percentagem

9 Número de entrevistas realizadas e representatividade por município

10 Perfil da amostra (em \%): sexo, idade e renda

11 Respostas aos valores propostos sem excluir protestos

12 Justificativas para respostas "não" e "não"

13. Estimativas dos modelos, sem excluir manifestações de protesto

14 Amostra (em \%): sexo, idade e renda, excluídos os protestos

15 Respostas aos valores propostos, excluídos os protestos 98

16 Estimativas do modelo logito, excluídos os protestos 99 
viii.

\title{
VALOR ATRIBUÍDO PELA POPULAÇÃO ÀS MATAS CILIARES DA BACIA DO RIO CORUMBATAÍ, SP
}

\author{
Autor: Caetano Brugnaro \\ Orientadora: Profa Dra Zilda Paes de Barros Mattos
}

\section{RESUMO}

Este trabalho foi uma aplicação do método de valoração contingente, tendo-se adotado o modelo de escolha dicotômica com limite duplo, sob distribuição logística de probabilidade, visando estimar o valor monetário do recurso ambiental representado pelas matas ciliares. $O$ método é aceito em diversos países como meio de se estimar valores em questões ambientais, mas, no Brasil, há muito poucas aplicações como apoio à formulação de políticas. $O$ estudo de caso foi um hipotético projeto de reposição das matas ciliares da bacia do rio Corumbataí, com sete municípios, no estado de São Paulo, Brasil.

Três aspectos importantes relacionam-se a matas ciliares: suas funções ambientais, os estatutos legais sobre sua preservação e reposição e questões econômicas derivadas do uso do solo como fator de produção agrícola. Dado que os serviços ambientais geralmente são considerados externalidades, sem preços relacionados tanto do lado de quem se dispõe a pagar pelo acesso como do lado de quem se dispõe a aceitar compensação pelo suprimento dos serviços, a análise benefício-custo torna-se uma tarefa complexa.

O levantamento de dados ocorreu no período de outubro a dezembro de 1999, tendo-se realizado 991 entrevistas, das quais se extraiu numa amostra 
ix.

aproveitada com 930 observações. O valor médio da disposição a pagar (50\% de probabilidade de aceitar o pagamento) foi estimado em $R \$ 2,06$ mensais, na forma de um adicional hipotético nas contas de água residenciais. Esse valor equivale a cerca de $R \$ 274$ mil mensais quando se considera toda a população. A estimativa do modelo com limite simples, comparado com o limite duplo, mostrou uma maior disposição a pagar média e maiores variâncias dos parâmetros estimados, o que confirma resultados de estudos anteriores, e uma maior proporção de acerto nas probabilidades estimadas.

A pesquisa levantou também as causas de não concordância com o pagamento, tendo sido as principais o preço proposto (variável na amostra), a atribuição do problema ao "governo" ou aos agricultores, a desconfiança no uso dos recursos pelas entidades envolvidas e o excesso de impostos e taxas já pagos. Como resultado desses e de outros motivos, a probabilidade de o indivíduo não aceitar qualquer valor pela implementação do projeto foi estimada em $23 \%$. 


\title{
VALUE ASSIGNED BY POPULATION TO THE CORUMBATAÍ RIVER WATERSHED'S RIPARIAN FORESTS, SP
}

\author{
Author: Caetano Brugnaro \\ Adviser: Profa Dra Zilda Paes de Barros Mattos
}

\section{SUMMARY}

This study was an application of the contingent valuation method (CVM), using double bounded dichotomous choice model under a logistic probability distribution, aming to estimate the monetary value of riparian forest as an environmental resource. CVM is accepted in several countries as a way to estimate values in environmental questions. But there are very few CVM applications as a decision aid to policy makers, in Brazil. The study case was a hypothetical project on riparian forests restoration in the Corumbatai river watershed, whith seven municipios, in the state of São Paulo, Brazil.

There are three important aspects related to riparian forests: their environmental functions, the legal statements on their preservation and restoration and the economics concems emerging from soil's use as an input to agricultural production. Because environmental services are usually considered externalities, with no price assigned to it by neither those wiling to pay (WTP) for it nor the ones willing to accept (WTA) for going without it, beneefit-cost analysis becomes a complex task.

The survey was carried out in the period October to December 1999, interviewing 991 individuals, from whom a 930 observations net sample was extracted. The mean WTP ( $50 \%$ probability of agreement about the payment) 
xi.

was estimated at $\mathrm{R} \$ 2.06$ monthly as a hypothetical extra charge on households' water consumption bill. Taking into account the whole population, total value approximated $R \$ 274,000$ per month. The estimation of the single bounded model, as compared to the double bounded, showed a higher mean WTP and a higher variances of the estimated parameters, which confirm other studies' results, and a higher correct prediction rate.

The causes of no WTP were also investigated being the most important ones the high price offered (variable among the sample), inputation of the problem to "government" or farmers, peoples' distrust in fund's use by the agencies in charge of water services and the excessive amount of taxes already being paid. As a result of these and other motivations, it was estimated a probability of $23 \%$ that the individual would not agree to pay any value for riparian forest restoration. 


\section{INTRODUÇÃO}

Este trabalho tem por objetivo principal estimar o valor atribuído pela população às matas ciliares, tomando-se como aplicação empírica o caso da bacia do rio Corumbataí, SP. Trata-se de uma aplicação de valoração contingente, um dos métodos adotados para se estimar o valor monetário de bens não transacionados em mercado, sob uma perspectiva neoclássica.

\subsection{O problema e justificativa}

É fato notório que o processo acelerado de urbanização e industrialização ocorrido no Brasil, especialmente nos séculos dezenove e vinte, aliado à expansão da agricultura baseada na incorporação de novas áreas, vem trazendo como uma de suas conseqüências a agressão acentuada aos recursos hídricos, seja pela poluição química e orgânica, seja pela alteração física e limnimétrica dos corpos d'água, em especial pela erosão de suas margens e áreas próximas, com conseqüente assoreamento e alteração da topografia submersa. Sem registro formal na literatura, mas com reiterada divulgação nos meios de comunicação massal, aparecem os casos de rios (como o Taquari, por exemplo, no Centro-Oeste brasileiro) que, em muitos trechos, já não mais permitem navegação em boa parte do ano e mesmo a piracema tem sido comprometida, devido ao assoreamento severo, atribuído à erosão em áreas de expansão agrícola sem técnicas adequadas de conservação. É visivel a poluição dos corpos d'água, em graus variáveis, por dejetos industriais e urbanos sem tratamento adequado e por material (químico 
e orgânico) carreado pela água da chuva, com origem em áreas agrícolas, obras viárias e aglomeramentos urbanos. Este trabalho tem seu ponto de partida num desses aspectos, omitida a discussão sobre seu grau de relevância relativa: o papel das matas ciliares como agentes capazes de reduzir a poluição das águas por material originado nas áreas agrícolas e de prover outros serviços ambientais.

O excesso de água da chuva, isto é, a fração que não se infiltra no solo nem evapora, escorre sobre a superfície carregando terra (erosão), material orgânico particulado e resíduos químicos, como fertilizantes, pesticidas e outros compostos utilizados na agropecuária. Além disso, há um fluxo de água sob a superfície do solo, que pode carregar substâncias químicas em solução (Lima, 1989). Especificamente em relação ao escorrimento superficial, quanto menos barreiras esse fluxo tem em seu trajeto, maior a quantidade de detritos levados aos corpos d'água, causando um tipo de poluição não pontual (difusa), com diversas conseqüências ambientais e econômicas.

Há uma série de técnicas recomendadas para se mitigar o problema, como, por exemplo, de forma extremamente sucinta, controle das enxurradas geradas ou recebidas pelas estradas (pavimentadas ou de terra), práticas mecânicas e agrícolas de conservação do solo e manutenção ou implantação de uma barreira física e biológica às margens dos corpos d'água. Como referência, técnicas adequadas de conservação estão descritas detalhadamente em manual técnico coordenado por Lombardi Neto \& Drugowich (1994). A proteção à margem dos rios é representada por uma faixa florestada, que recebe a denominação de mata ciliar, mata ripária, mata de galeria e outras ${ }^{1}$. Analisando o programa norte-americano de conservação, Ribaudo (1989) atribuiu à vegetação ciliar a responsabilidade por $25 \%$ da

\footnotetext{
${ }^{1}$ Sobre revisão minuciosa da terminologia aplicável neste caso, ver Troppmair \& Machado (1974) e Mantovani (1989).
} 
"filtragem" (efeito tampão) de resíduos resultantes de atividades agrícolas, o que confere a esse recurso papel importante na qualidade ambiental.

Tomando como exemplo a bacia do rio Corumbataí ${ }^{2}$, López (1997) estimou que a carga de sedimentos gerados por atividades agrícolas atingiu 13,3 milhões de toneladas no período 1985-1994 (média anual de 1,32 milhão de toneladas), 2,37 vezes a carga considerada tolerável. Como conseqüência, o custo adicional para tratamento de água para consumo urbano foi estimado em quase 5,5 milhões de reais no mesmo período (média anual de $548 \mathrm{mil}$ reais), todos os valores a preços de dezembro de 1995. Esses valores eventualmente podem ser maiores se considerados outros custos, como redução do assoreamento (dragagem), como estimado por Margarido (1994), ou sobre serviços prestados pelos corpos d'água, como produção de energia elétrica, navegação, lazer e outros (Marques, 1995).

A manutenção e mesmo a reposição ${ }^{3}$ de matas às margens dos corpos d'água vêm merecendo destaque crescente nas discussões sobre o ambiente. A recuperação de matas ciliares, segundo Kageyama et al. (1989), tem por objetivos: (i) restaurar a diversidade vegetal existente no passado, através da recriação aproximada da estrutura e composição de espécies vegetais, e (ii) gerar benefícios, pela inibição da erosão e pela retenção de resíduos, o que concorre para a melhoria da qualidade da água (proteção de mananciais). Os autores propõem, como estratégia de reposição de matas ciliares: (a) renovação natural baseada em fragmentos florestais remanescentes, devendo-se evitar, nas áreas de interesse, qualquer perturbação por atividade humana, ou (b) no caso de ausência de banco

\footnotetext{
${ }^{2}$ Ver caracterização geográfica e sócio-econômica desta área no capítulo 3.

${ }^{3}$ O termo reposição será utilizado neste trabalho, apesar da conceituação de Bromley (1995), que define "restauração" como a replicação exata do ambiente anterior, no mesmo local; "reabilitação" como remoção de influências extemas e colocação do sistema em atividade normal, e "substituição" como a criação de um outro sistema no local do anterior.
} 
natural de sementes, o que ocorre com freqüência em áreas cultivadas há muito tempo, plantio de espécies não mais existentes no local, com vistas a acelerar o processo de restauração.

Segundo Crestana (1994), a regeneração natural pode ser esperada em áreas pouco perturbadas e que mantêm características de fauna e flora típicas da área a ser preservada. Exige fonte de material regenerativo nas proximidades. Em locais onde já existe formação arbórea, porém pouco diversificada, uma técnica disponivel é o "enriquecimento" da floresta, pelo plantio de espécies secundárias iniciais e tardias ${ }^{4}$ à sombra da vegetação existente. Em áreas severamente desflorestadas, em que o banco de sementes já se degradou devido ao tempo de uso agrícola, a técnica ideal é o plantio simultâneo de espécies típicas dos diversos ciclos de formação das matas. Alternativamente, tem-se optado pela seleção de espécies da floresta original e sua distribuição no campo, e tem-se verificado até o plantio aleatório de espécies não selecionadas. Mesmo o reflorestamento com espécies comerciais, como eucalipto, por exemplo, pode, sob certas condições, segundo Kageyama et al. (1989), propiciar ambiente adequado ao surgimento de espécies secundárias e de estágios subseqüentes.

Exemplos de casos concretos de recuperação de áreas degradadas são os relatados em Barbosa (1989), em Lopes et al. (1996) e no relatório do $3^{\circ}$ Simpósio Nacional de Recuperação de Áreas Degradadas (Simpósio..., 1997). Também, diversos municípios vêm implantando projetos de reposição de matas ciliares por meio de convênios com o Instituto Brasileiro do Meio Ambiente (IBAMA) ${ }^{5}$, de iniciativas locais e de consórcios de municípios com

\footnotetext{
${ }^{4} \dot{E}$ usual dividir-se a formação de uma floresta em estágios, de acordo com as características e hábitos das espécies predominantes em cada um: pioneiras, secundárias iniciais, secundárias tardias e clímaces. Ver, por exemplo, Crestana (1994) e citações em Azevedo (1994).

${ }^{5}$ Informação obtida na Intemet, http://www.ibama.gov.br, em agosto de 1999.
} 
interesses ambientais comuns. Um outro exemplo, não publicado, é o projeto em desenvolvimento na Agropecuária Cresciumal, no município de Leme, SP. Segundo depoimento de seu proprietário, a reposição de matas em áreas de preservação está propiciando, inclusive, o retorno de espécies animais até então desaparecidas da região.

Filosoficamente, a legislação de um país democrático reflete os anseios de sua sociedade, isto é, trata-se de um conjunto de regulamentos destinados a maximizar o bem-estar coletivo, num dado contexto cultural e econômico. Se a prática mostra casos em que isso não ocorre, é um indício de distorção nos mecanismos de geração e aplicação das leis, problema que este trabalho não tem a ousadia nem a competência necessárias para abordar. Feita essa ressalva, registre-se que a legislação brasileira trata com algum detalhe da regulamentação sobre a vegetação em áreas consideradas de preservação permanente, em alguns casos conferindo-lhe a condição de recursos praticamente intocáveis, inclusive exigindo sua reposição onde não mais existe e deveria existir (ver seção 1.3).

A reposição de matas ciliares (e em outras áreas consideradas de preservação permanente) afeta diretamente as empresas que exploram economicamente essas áreas e, sob a ótica privada, representa uma interferência no direito de propriedade, pela abdicação de receitas e pela necessidade de realocar recursos (terra, principalmente) para uma atividade não passível de exploração econômica convencional. $A$ análise benefício-custo da manutenção de matas ciliares e sua reposição onde foram eliminadas é uma tarefa complexa. Como acontece, em geral, com bens ambientais, há uma séria dificuldade em se mensurar os benefícios e os custos. De um lado, há o aparente interesse social em dispor de "mais ambiente", ao passo que as terras necessárias, em grande parte, pertencem a empresas agrícolas, com uso atual ou potencial para produção de alimentos, fibras e energéticos. 
6.

Restringindo a discussão ao caso das matas ciliares ${ }^{6}$, o confronto de interesses gera, então, o debate: o que é benefício e o que é custo, dependendo de que agente ou grupo de interesse faça a análise. Por exemplo, Bromley (1996) considera que os agricultores tendem a desejar mais terras agricultáveis, ou manter as atualmente utilizadas, sob a visão de que a preservação (ou aumento) de serviços ambientais supridos por suas propriedades gera benefícios a toda a coletividade, sendo passivel de compensação financeira. Em confronto, os "ambientalistas" pressionam por mais "ambiente natural", argumentando que a redução da qualidade ambiental é passível de punição. No estado de São Paulo, a área com matas naturais não chega a $10 \%$ da área agrícola total (Pino et al., 1997), contra o mínimo de $20 \%$ estabelecido em lei.

O cerne da questão é que produtos agrícolas têm preço de mercado, com a sinalização que isto representa em termos de planejamento empresarial, ao passo que benefícios ou danos ambientais são externalidades não captadas pelo mercado e não adequadamente incluídos no processo de decisão do empresário. Estimativas do valor de bens não transacionados em mercado dependem de métodos alternativos de avaliação (ver capítulo 2).

Confrontando dados a partir de algumas funções ambientais, como controle da erosão, fixação biológica de nitrogênio e depuração da água, Margarido (1994) estimou em 0,94 a relação benefício-custo da preservação ambiental em área de estação ecológica no estado de São Paulo, contra 1,20 de hipotético projeto alternativo de exploração agrícola da área. Essa diferença não tem respaldo no sistema econômico vigente se tiver que ser absorvida pelo

\footnotetext{
${ }^{6}$ Relegando a um outro contexto o problema de poluição causada por esgoto urbano, despejos industriais, lixo não coletado devidamente e dejetos carreados por mau planejamento viário e de uso do solo agrícola.
} 
empresário, mesmo porque eventuais benefícios no âmbito da empresa rural podem se fazer sentir apenas no longo prazo (Toledo, 1997).

A título de ilustração: Azzoni \& Isai (1994) estimaram que, para manter $7,68 \%$ do território paulista sob proteção, em sete modalidades diferentes de áreas de preservação florestal, a perda de receita fiscal pelo Estado corresponde a $0,05 \%$ do Produto Interno Bruto (PIB) estadual, além da necessidade de se transferir aos proprietários, a título de compensação, de $0,07 \%$ a $0,12 \%$ do PIB, todos os valores referentes a 1990 .

Tomando como base os valores de arrendamento de terras no estado de São Paulo em novembro de 1995 (Informações Econômicas, 1996) e utilizando como ponderação os dados de uso da terra obtidos de Pino et al. (1997), pode-se estimar em $R \$ 117,00$ por hectare e por ano a renúncia anual de receita pelos agricultores dos municípios que contêm a bacia do rio Corumbataí, área objeto deste estudo.

Nessa bacia, o abastecimento de água para uso urbano é feito a partir de captação profunda ou superficial em locais, quando há avaliação disponivel, considerados de alto ou altíssimo risco de impacto ambiental. Entre as medidas recomendadas para preservação ou melhoria da qualidade desses mananciais estão o controle da erosão, a preservação da vegetação ciliar e o aumento da cobertura florestal (São Paulo, 1994).

No caso de áreas degradadas, a reposição das matas ciliares é uma perspectiva que pode vir por consenso (solução negociada), por decisão política ou por força da lei. Nos dois últimos casos, tendem a surgir conflitos de interesse entre os proprietários das terras, em defesa de receitas econômicas que serão abandonadas (e contra a incidência dos custos de plantio e condução das matas, se feitos com recursos próprios) e outros segmentos da sociedade, estes reivindicando maior disponibilidade de boa qualidade ambiental. É muito provável que tais situações surjam nos municípios que englobam a bacia do rio Corumbataí. 
8.

A solução de conflitos dessa natureza geralmente é mais eficaz quando tem respaldo popular, obtido diretamente ou por meio de representantes democraticamente eleitos. É neste sentido que este trabalho visa estimar o valor atribuído pela população às matas ciliares, como um subsídio aos formuladores de políticas ambientais da região.

Desta introdução afloram três aspectos principais ligados às matas ciliares: ambientais, legais e econômicos. Esses temas serão tratados nas seções seguintes, deduzindo-se daí os objetivos deste estudo.

\subsection{Papel das matas ciliares na qualidade ambiental}

O material resultante da erosão do solo e outros resíduos carreados para os corpos d'água podem causar impactos, segundo Marques (1995):

a) sobre a biodiversidade aquática, pelo efeito de (i) resíduos orgânicos que provocam aumento da demanda por oxigênio e contaminação por pesticidas e de (ii) material em suspensão, que provoca aumento da turbidez da água, vedando a luz solar e reduzindo a fotossintese, com conseqüente redução da oferta de oxigênio, afetando toda a cadeia que vai da produção de fitoplânctons à alimentação e reprodução de espécies de peixes, consequentemente dos elos situados acima na cadeia alimentar; além disso, a sedimentação desse material reduz a fixação de plantas macrófitas e altera o habitat natural de invertebrados, provocando desequilíbrio entre populações de peixes em favor de espécies mais rústicas (menos nobres);

b) sobre a recreação e a navegacão, pela redução da capacidade de tráfego e por aumentar os custos de dragagem;

c) sobre o abastecimento de áqua, pela redução da capacidade dos reservatórios, por alterações na temperatura da água e pelo fato de os nutrientes carreados aumentarem a proliferação de plantas aquáticas; 
d) sobre ambientes externos aos corpos d'água, pelo aumento da área inundada ou inundável, pelo menor volume de água armazenada, pelo maior custo de tratamento de água para uso urbano, pela menor capacidade reguladora dos reservatórios, pelo desgaste em equipamentos de captação, adução e tratamento e pelo desgaste em equipamentos de hidrelétricas.

As vegetações ciliares, atuando como filtro e depósito de resíduos químicos e orgânicos, podem funcionar como reguladoras do fluxo de água, sedimentos e nutrientes (Lima, 1989; Ribaudo, 1989; Bromley, 1996). Na forma sistematizada por Mueller (1996), as matas ciliares têm como funções principais: (i) proteção das terras ribeirinhas contra erosão, devido à resistência oferecida pelo emaranhado de raízes; (ii) proteção de mananciais; (iii) anteparo aos detritos carreados pelas enxurradas, diminuindo impactos sobre a vida aquática, a navegação e a qualidade da água para consumo humano, consumo animal, geração de energia e irrigação; (iv) abastecimento do lençol freático, pela suavização e certa contenção do impacto da água da chuva e (v) auxílio à conservação da vida aquática, evitando alteração na topografia submersa, propiciando algum controle da temperatura da água e fornecendo alimentos na forma de flores, frutos e insetos.

A vegetação ribeirinha é um componente fundamental do ecossistema que inclui a área de inundação, a camada de solo sob a vegetação e as interações com o meio (Lima, 1989). A vegetação ripária tem função reguladora do fluxo de água, sedimentos e nutrientes entre as terras mais altas e o ecossistema aquático, desempenhando o papel de filtro ou sistema-tampão.

Entretanto, se a floresta ripária retém resíduos, pode também ser responsável por sua geração. Pozo et al. (1997) compararam as quantidades de material vegetal (folhas caídas, frutos, flores, ramos e outros) de mata decídua mista e de Eucaliptus globulus, concluindo que, no primeiro caso, a quantidade de material gerado foi muito maior. $O$ aporte de resíduos orgânicos nos cursos d'água pode representar um fator negativo no tratamento da água 
para consumo (humano, animal, agrícola ou industrial). Além disso, as matas podem se constituir em pontos de risco de incêndio (de difícil controle) e em abrigo de predadores de animais domésticos e de plantações.

Além de sua atuação principalmente física sobre material particulado, as matas ciliares têm também a capacidade de absorver substâncias dissolvidas na água, incluindo-se ai os fluxos hídricos abaixo da superfície do solo. Snyder et al. (1998) estimaram que a vegetação ciliar reduziu em $48 \%$ a quantidade de nitratos na água em comparação com os teores medidos na área cultivada adjacente. Para fosfato e amônia, concluíram que não existe uma tendência espacial de distribuição, isto é, não foi possivel concluir em que medida e em que gradiente a vegetação ripária é capaz de reter aqueles compostos. Segundo Lowrance et al. (1997a), a retenção de resíduos depende do formato e da posição relativa da vegetação ripária. Os resultados de seu estudo mostraram que a retenção de nitratos, de resíduos de enxurrada e de nitrogênio total situam-se entre $50 \%$ e $90 \%$ dos valores originais, esperando-se que em solos com maior declividade que o do experimento a retenção seja menor. As taxas de retenção de fósforo foram muito menores que as de nitrogênio.

Um programa implementado pelo Departamento de Agricultura dos EUA (USDA) admite que a vegetação ripária seja composta de três elementos: (a) uma faixa com floresta de espécies nativas, imediatamente contígua às margens do rio e em toda a sua extensão; (b) logo a seguir, uma faixa de floresta comercial, com manejo controlado e (c) uma faixa com grama ou outra vegetação herbácea entre a floresta controlada e a área com exploração agrícola (Lowrance, 1996). Para as condições norte-americanas, a floresta controlada pode ser, por exemplo, de pinheiro, como utilizado no experimento de Lowrance et al. (1997b), em que a largura total da faixa ripária foi de 50 metros e o objetivo foi medir a retenção de herbicidas (atrazine e alachlor) aplicados em lavoura de milho. Os teores observados nas proximidades do rio 
foram de no máximo $1 \mu \mathrm{g} / \mathrm{L}$, contra $34,1 \mu \mathrm{g} / \mathrm{L}$ e $9,1 \mu \mathrm{g} / \mathrm{L}$ na borda da área de cultura, respectivamente para os dois herbicidas. Resultados de natureza semelhante (retenção de compostos químicos de uso agrícola) estão relatados em muitos outros trabalhos como, por exemplo, em Hubbard \& Lowrance (1994), Butturini \& Sabater (1996), Horwath et al. (1996), Mander (1996), Van Dijk \& Kwaad (1996), Fennessy \& Cronk (1997), Hubbard \& Lowrance (1997), Uusi-Kaemppae et al. (1997), Barfield et al. (1998) e Hefting \& Klein (1998).

Outros aspectos funcionais das matas ciliares, como diversidade botânica e habitat da fauna, são mais difíceis de generalizar, por dependerem de outros componentes ambientais, como clima, tipos de solo, topografia e regime hídrico, e da existência de remanescentes florestais intactos que sirvam de referência.

\subsection{Aspectos legais do problema}

A utilização dos serviços de um determinado recurso nos processos econômicos de países capitalistas está associada aos direitos de propriedade, isto é, direitos de uso do recurso sob determinadas condições; portanto, incluem também as limitações ao uso do recurso (Randall, 1987). Segundo esse mesmo autor, para se atingir a eficiência no processo econômico, os direitos de propriedade devem: (a) ser perfeitamente especificados, o que inclui seu pleno conhecimento pelos agentes econômicos; (b) ser formulados de maneira que todas as conseqüências de uma ação (favoráveis ou não) recaiam exclusivamente sobre seu autor; (c) ser transferiveis; (d) poder ser cumpridos e (e) ter garantido seu cumprimento. Para que se garanta o cumprimento dos direitos de propriedade, é necessário que qualquer violação seja descoberta, seu autor identificado (e detido, quando for o caso) e que se the apliquem as penalidades estipuladas. Estas devem ter custos suficientemente altos que superem os benefícios da violação. Entretanto, a garantia do exercício do 
direito de propriedade e da observância de suas limitações implica em custos de transação, não raro elevados, com aparatos de fiscalização, de sustação de atos não permitidos, de julgamentos, de execução das decisões e outros.

No caso brasileiro, a exploração de matas está disciplinada no chamado segundo Código Florestal, instituído pela Lei n 4.771 (Brasil, 1965), na Constituição federal (Brasil, 1988), na Lei nº 7.754 (Brasil, 1989), na chamada Lei Agrícola, de $n^{\circ} 8.171$ (Brasil, 1991), em resoluções do Conselho Nacional do Meio Ambiente (CONAMA) e em leis e decretos estaduais e municipais. Pela legislação federal, as florestas e demais vegetações naturais são consideradas de interesse social, sendo o "ambiente ecologicamente equilibrado" direito de todos os cidadãos e bem de uso comum (Brasil, 1988).

O Código Florestal (Brasil, 1965) e suas alterações subsequentes normatizam a existência de áreas de preservação permanente, isto é, onde não é permitido o corte raso da vegetação. Podem ser de administração pública, como os parques e reservas (federais, estaduais e municipais), ou de responsabilidade privada. Nos perímetros urbanos, as áreas de preservação são definidas nos planos diretores e por leis de uso do solo locais, desde que não contradigam o estabelecido na lei federal (Art. $2^{\circ}, \S$ único). Para as áreas rurais de responsabilidade privada, a lei estabelece percentuais mínimos da área total dos imóveis que devem ser mantidos com vegetação permanente. Para a região geográfica em que está o estado de São Paulo, esse percentual é de $20 \%$.

São consideradas de preservação permanente:

i) as margens de reservatórios d'água e de nascentes de qualquer tipo, neste caso com raio mínimo de 50 metros;

ii) topos de morros, montes, montanhas e serras;

iii) encostas com declividade superior a $45^{\circ}$;

iv) dunas, restingas e mangues; 
v) bordas de tabuleiros ou chapadas, com faixa mínima de 100 metros a partir da linha de ruptura do relevo, e

vi) áreas em altitudes superiores a 1.800 metros.

Além dessas, a legislação dá especial atenção às vegetações ciliares como áreas de preservação permanente. Estabelece como exigência as larguras mínimas anotadas na Tabela 1, de acordo com a largura do rio.

Tabela 1. Largura mínima da faixa com mata ciliar.

\begin{tabular}{rc}
\hline Largura do rio $(\mathrm{m})$ & Largura da mata ciliar $(\mathrm{m})$ \\
\hline até 10 & 30 \\
de 10 a 50 & 50 \\
de 50 a 200 & 100 \\
de 200 a 600 & 200 \\
acima de 600 & 500 \\
\hline
\end{tabular}

Fonte: Brasil (1965).

Não se encontraram trabalhos que dêem sustentação científica aos dados da Tabela 1. Lima (1989) recomenda que a largura da mata ciliar seja de 12 a 30 metros de cada lado do rio, dependendo da topografia e do tipo de solo, isto é, a largura da faixa com vegetação ripária deve ser variável com as condições da bacia hidrográfica. Em estudo sobre o papel da vegetação ciliar em região da Austrália, Bren (1998) não considera razoável o princípio de que rios mais largos devam ter necessariamente faixas ciliares mais largas. Recomenda, para efeito de projeto, que se subdivida a área de estudo em unidades de captação da água, calcule-se $10 \%$ da área de cada unidade (destinados à vegetação ciliar) e, com base no comprimento do segmento do rio em cada unidade, estabeleça-se a largura da faixa.

As leis $n^{0} 7.754$ (Brasil, 1989) e $n^{0} 8.171$ (Brasil, 1991) tratam as reservas legais de maneira severa, obrigando o proprietário rural a repor a vegetação onde deveria existir e não mais existe, à razão de 1/30 por ano da área legalmente estabelecida. Como já mencionado, para o estado de São 
Paulo a lei determina que os imóveis rurais têm de preservar no mínimo $20 \%$ \} de sua área total com vegetação permanente. O Art.16, $\S 1^{\circ}$, do Código Florestal, entretanto, abre um exceção para os imóveis com 20 a 50 hectares, permitindo que "os maciços de porte arbóreo, frutíferos, ornamentais ou industriais" sejam considerados como parte da reserva estabelecida em lei.

Em que pese existir há bom tempo legislação restritiva, a área com vegetação natural vem decrescendo continuamente. Dados de um levantamento publicado por Pino et al. (1997), para o estado de São Paulo, permitem calcular que a cobertura com vegetação natural não especificada abrangia 9,8\% da área total das unidades de produção agrícola em 1995-96. Cerca de $26 \%$ das unidades $(11,4 \%$ da área total) eram de tamanhos entre 20 e 50 hectares. As áreas com reflorestamento e com culturas perenes representaram, nesse estudo, respectivamente $4,1 \%$ e $6,7 \%$ da área total.

$\mathrm{Na}$ antiga Divisão Regional Agrícola (DIRA) de Campinas, que continha a maior parte da região deste estudo, a área com vegetação natural vem continuamente decrescendo, com base em trabalho de Caser et al. (1998), que classificaram as matas nativas como cerrado, cerradão e mata natural (Figura 1). Dos 416 mil hectares existentes em 1972, restavam, em 1995, pouco mais de $34 \%$, embora a vegetação classificada como mata natural tenha mantido cerca de $58 \%$ de sua área, no mesmo período.

A eliminação das matas de preservação permanente tem motivação principalmente econômica, segundo Azevedo (1994) que, embora no âmbito restrito da microrregião estudada (médio rio Jaguari-Mirim, estado de São Paulo), observou que, quanto mais recente a aquisição da propriedade rural e quanto maior a área relativa ocupada por mata ciliar, maior a probabilidade de desmatamento. Isto reflete a visão privada de irracionalidade da preservação face à necessidade de sobrevivência econômica. 


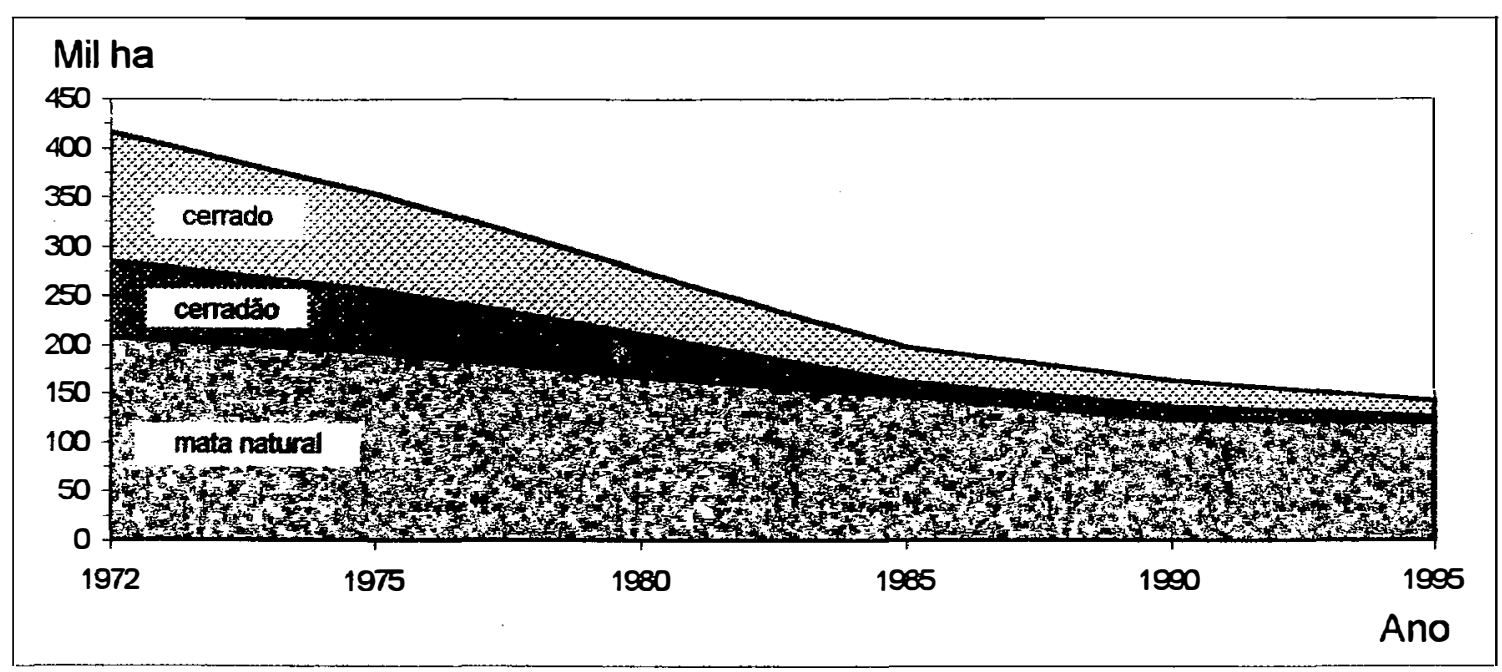

Figura 1. Evolução da cobertura com vegetação natural na DIRA de Campinas, 1972-95.

Fonte: dados originais em Caser et al. (1998).

Apesar das evidências de que a área com vegetação natural está muito aquém da estabelecida, os instrumentos legais não vêm sendo acionados pelo Ministério Público, pelo menos de forma generalizada, provavelmente pelas dificuldades de levantamento das ocorrências, notificação dos infratores e acompanhamento da execução legal. A preservação florestal, na visão de Azevedo (1994), depende da aplicação de leis restritivas, porque "campanhas de conscientização parecem ter resultado mínimo e instável" no convencimento de pessoas que são, ao mesmo tempo, vítimas e agentes da destruição.

A manutenção e a reposição de matas em áreas de preservação permanente sob responsabilidade privada implicam em forçar as empresas agrícolas a dispor do recurso terra em quantidade menor do que o máximo possivel se não houvesse restrição, questões ambientais à parte. Assim, as restrições vigentes impõem às empresas um nível de eficiência condicionado pelas especificações dos direitos de propriedade (Randall, 1987). As 
16.

compensações previstas ao empresário rural pela manutenção de áreas de preservação se resumem a uma vaga menção a indenização do valor de culturas eventualmente existentes na área a ser reflorestada (Brasil, 1965, Art.18, $\S 1^{\circ}$ ) e à isenção do Imposto Territorial Rural (ITR) correspondente á área em questão. Neste segundo caso, Bacha (1993) mostra-se cético quanto à eficácia do dispositivo, por considerar os valores do imposto insuficientes para compensar a renúncia das receitas atualmente obtidas nas áreas com explorações econômicas ${ }^{7}$.

\subsection{Aspectos econômicos do problema}

A teoria neoclássica elege o mecanismo de mercado como a ferramenta para se atingir a eficiência econômica, cujo principal sinal é o preço de cada recurso, bem ou serviço. A eficiência econômica, com o respectivo estabelecimento dos preços de mercado de bens e serviços (doravante, bens de mercado), exige que estes tenham os atributos de divisibilidade, poder de exclusão de consumidores e rivalidade no consumo, como se aprende, por exemplo, em Randall (1987). Este autor evita o termo "bens públicos" utilizado, entre outros, por Hueting (1991) e caracterizados como não-detentores dos atributos mencionados. Samuelson (1954) refere-se a bens de consumo coletivo.

Situações em que não se consegue aferir preço sob condições de busca simultânea da maximização da utilidade do consumidor (sujeita à restrição orçamentária) e da maximização do lucro das empresas sob determinada estrutura de produção são comumente atribuidas a falhas, ou

\footnotetext{
${ }^{7}$ Uma análise jurídica sobre as reservas florestais pode ser encontrada em Machado (1999), em que o autor sintetiza os dispositivos legais e ações judiciais cabíveis em caso de descumprimento da lei.
} 
ineficiências do mercado, que Randall (1987) insiste em atribuir ao fato de o consumo do bem ser não-excludente ou não-rival, características essas que podem estar associadas a questões culturais e políticas ou à natureza do bem em questão.

Os recursos naturais têm sido encarados como detentores de funções semelhantes às de outros ativos: fornecer matérias-primas e energia para o processo econômico, pressupondo-se que o uso do recurso leva à sua escassez e conseqüente aumento do preço relativo, permitindo que se estabeleçam taxas ótimas de extração e depleção. A isto vem se contrapondo uma outra abordagem em que se considera que os recursos naturais têm, além daquela, outras duas funções: assimilar resíduos gerados no processo econômico e prover outros serviços, como recreação, saúde, cultura, educação, ciência e estética (paisagem), além da manutenção de ciclos naturais e funções climáticas e ecológicas (Barbier, 1990; Hinterberger et al., 1997). A maioria desses serviços do ambiente não é transacionada em mercado.

A derrubada de matas tem como principais motivações o uso das terras para produção de alimentos, a expansão da fronteira agrícola, a construção de rodovias, a instalação de pastagens e o uso comercial da madeira. Como conseqüências, ocorre o empobrecimento do solo, a destruição da biodiversidade e a migração ou desaparecimento de espécies animais, às vezes de forma permanente. Pelo fato de muitas espécies vegetais atingirem a maturidade somente após dezenas de anos, a destruição de matas tem efeito irreversível na prática, seguido pelo surgimento de vegetação sucessora nas áreas desmatadas e não utilizadas (Winpenny, 1993).

As áreas ribeirinhas sem vegetação natural estão sendo, em sua maior parte, utilizadas para atividades humanas tais como agricultura, indústria, habitação e vias de locomoção, o que torna complexo o estabelecimento de políticas de reposição das matas ciliares, como estabelece a legislação 
18.

brasileira. O problema crucial é determinar os níveis mínimo admissivel e máximo factível, trazendo como conseqüência uma questão política: em que circunstâncias deve o agricultor ser ressarcido por benefícios fornecidos à coletividade ou ser onerado por danos causados ao ambiente? Uma das formas de se enfrentar esta questão é por meio do respaldo social à implantação de políticas que visem contornar o problema.

Conseqüências de uma atividade econômica podem ser sentidas tanto no âmbito da própria atividade (produção, mercado) como fora dele, causando, neste segundo caso, o que se conhece por externalidade, que, para Randall (1987), só é assim entendida se induzir o indivíduo afetado, positiva ou negativamente, a interferir na sua causa, isto é, não Ihe ficar indiferente. Os agricultores, geralmente, não consideram em suas decisões privadas os custos e benefícios sociais dos efeitos que suas práticas agrícolas causam no ambiente externo à propriedade porque não são diretamente revelados pelos preços de mercado, abrindo campo para políticas que afetam direta ou indiretamente as tecnologias de produção (Kazmierczak Jr. \& Hughes, 1996). O agricultor não consegue obter pagamento por externalidades positivas como, por exemplo, por benefícios gerados fora da sua propriedade pela conservação do solo ou da vegetação natural (Wuren \& Roy, 1993) ou outro benefício ambiental. Da mesma forma, não é taxado diretamente por prejuízos causados por sua atividade (externalidades negativas) como, por exemplo, o assoreamento de rios que afeta diretamente a oferta e qualidade de outros bens como energia elétrica e água. Uma das dificuldades encontradas para solucionar o problema, aparentemente, está no fato de a poluição causada por atividades agrícolas ser, geralmente, difusa, isto é, não ocorrer em pontos perfeitamente identificáveis no espaço.

No modelo neoclássico, no entender de Tomer (1992), as empresas são tipificadas como "máquinas de gerar lucros", tendo compromisso social com seus proprietários, cujos estímulos são os mercados (de fatores e bens) e 
19.

normas que visam regulamentar seu comportamento. A poluição de bens públicos, como ar e água, por exemplo, é vista exclusivamente como falha de mercado, devendo as questões ambientais ser consideradas como restrições no modelo de otimização (Flores, 1996; Flores \& Carson, 1997). Por outro lado, ambientalistas advogam que a natureza tem suas próprias leis e estas devem moldar o comportamento humano (Vedeld, 1994). Se, no caso de bens de mercado, o preço reflete o valor marginal atribuído pelo consumidor, quando se trata de bens ambientais esse valor usualmente não está disponível.

Do ponto de vista da análise econômica, o capital artificial é um substituto quase perfeito dos recursos naturais, mas o critério do valor presente do fluxo de custos e benefícios é problemático do ponto de vista da sustentabilidade (Daly, 1990), com critérios econômicos às vezes conflitantes com funções ambientais (Barbier, 1990). O processo econômico pode abrigar uma "armadilha social", isto é, a atividade que beneficia um agente econômico pode estar sendo danosa para a sociedade, como conseqüência dos direitos de propriedade em vigor ou da ignorância do indivíduo sobre conseqüências futuras (Constanza \& Perrings, 1990).

Para alguns autores, a essência comumente associada ao modelo envolve o ótimo de Pareto (ver, por exemplo, Randall, 1987). Os procedimentos de análise que consideram a disposição a pagar e a disposição a aceitar compensação pressupõem que os "ganhadores" no processo econômico potencialmente devem compensar os "perdedores", o que suscita o problema de como identificar esses agentes e como estipular valores.

O ponto de partida óbvio da análise é a situação atual. A este respeito, o trabalho de Bromley (1996) apresenta indicativos para políticas considerando três conseqüências das atividades agrícolas sobre o ambiente:

a) sobre a paisagem: de maneira simplificada, refere-se à sensação que causa aos sentidos humanos a disposição geral dos elementos físicos componentes do cenário rural. $\mathrm{O}$ autor ressalta que os produtos agrícolas têm 
mercados, o que não ocorre com os serviços oferecidos pela paisagem. No estabelecimento de políticas, surge o contraste: se estas induzem, estimulam ou forçam o aumento da disponibilidade do recurso, os agricultores tenderão a acreditar que estão "oferecendo" benefícios à sociedade e tentarão ser ressarcidos por isto; caso contrário, se as políticas são formuladas de maneira a propiciar a redução das "amenidades", os agricultores poderão ser acusados de estar causando danos ambientais e ser contra isso pressionados;

b) sobre o habitat: trata-se de características da agricultura que interferem no espaço e na sustentação de plantas e animais que não fazem parte dos fluxos de bens e serviços da empresa agrícola transacionados em mercado. Neste caso, os parâmetros mínimo e máximo tendem a ser definidos com menor grau de dificuldade que no caso anterior;

c) sobre o processo ecológico: características da agricultura que afetam, positiva ou negativamente, funções ecológicas além dos limites da atividade agrícola.

Com intuito meramente ilustrativo, considere-se a Figura 2 , onde $q^{0}$ simboliza o nivel atual, $q^{a}$ a quantidade considerada adequada pelos agricultores e $q^{s}$ o nivel de qualidade ambiental pretendido pela sociedade.

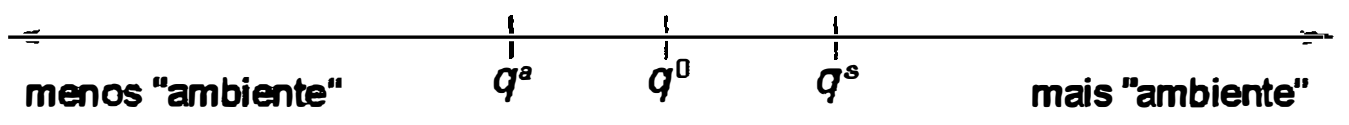

Figura 2. Espaço político para qualidade ambiental.

Fonte: adaptado de Bromley (1996).

O espaço $q^{s}-q^{a}$ representa a margem de manobra para decisões políticas sobre o tema. Como não há métodos seguros para determinar os niveis de $q^{a}$ e $q^{s}$, abre-se a possibilidade de sérias discordâncias. 
A esta abordagem adicione-se o conceito de sustentabilidade, que preconiza: (i) as taxas de exploração de um recurso natural devem ser iguais às respectivas taxas de regeneração; e (ii) as taxas de emissão de resíduos devem ser iguais à capacidade de assimilação dos ecossistemas onde são gerados (Daly, 1990). Este é o conceito de sustentabilidade forte, descrita, por exemplo, por Gutés (1996), que considera algumas funções do ambiente não substituiveis por capital artificial (man-made). A meta é fažer com que a presente geração possa atender suas necessidades preservando para as geraçōes futuras um estoque de capital natural que também lhes permita atender suas necessidades (Van Pelt, 1993). A este conceito contrapōe-se o de sustentabilidade fraca, que considera sustentável a economia em que a taxa de preservação é maior que a taxa de depreciação combinada do capital natural e do capital artificial, isto é, se mantém o estoque total de capital, sem diferenciálo entre natural e construído pelo homem.

A defesa de modelos econômicos de desenvolvimento sustentado envolve três tipos de argumentos (Perman et al., 1996): (i) de ordem moral, que significa não elidir o direito de gerações futuras de ter acesso a oportunidades iguais às que estão atualmente disponiveis; ; (ii) de natureza ecológica, preconizando que "a atividade econômica deve ser organizada de forma a manter a diversidade ecológica", eventualmente podendo ser considerada na categoria anterior; e (iii) de caráter econômico, requerendo provas de que o desenvolvimento sustentado é mais eficiente, ou que maximiza o bem-estar intertemporal da sociedade.

Entre as correntes principais que se têm destacado na abordagem do valor dos recursos naturais (Marques \& Comune, 1997; Perman et al., 1996), é

\footnotetext{
${ }^{8}$ A esse respeito, texto de Barrett (1998) é enfático ao apontar a contradição do modelo, que preconiza a eqüidade intergeneracional mas é incapaz de garantir o acesso equitativo da geração presente à riqueza gerada ou disponivel.
} 
necessário mencionar a que encara o ambiente como um conjunto de estoques e fluxos sujeitos às leis da termodinâmica. A primeira lei - matéria e energia não podem ser criadas nem destruídas - é a base de modelos de balanço material da atividade econômica, incluindo os fluxos de resíduos resultantes dos processos de produção, alguns com capacidade de dano ambiental. A segunda lei - ao longo do tempo, em sistemas isolados, ocorre declínio dos totais de energia e de matéria utilizáveis e aumento do grau de entropia enseja a previsão de alguns autores de graves conseqüências no longo prazo, suscitando contra-argumentos como a irrelevância desse longo prazo para a humanidade e a evidência de que o planeta Terra não é um sistema isolado, intercambiando energia com o meio externo ${ }^{9}$.

Para bens transacionados em mercado, os principios de soberania do consumidor e a revelação de suas preferências, sujeitas à restrição orçamentária, são passíveis de observação e objeto de farta literatura. No caso de bens não transacionados em mercado, o que se tem procurado desenvolver são técnicas que procuram simular um mercado, pressupondo que há uma curva de demanda para esses bens, e a literatura estrangeira a respeito também é bastante ampla.

A oferta de bens ambientais depende dos custos de se evitar a perda de suas funções vis-a-vis os gastos para restaurá-las e preservá-las, custos em geral progressivos à medida que a função é restabelecida e preservada mais completamente. Do lado da demanda, há sérias dificuldades para expressar as preferências dos consumidores em termos de mercado, sendo necessário lançar-se mão de métodos alternativos de avaliação.

${ }^{9}$ Considerações sobre divergências de enfoque entre "ecologistas" e "economistas" podem ser vistas, por exemplo, em Vedeld (1994) e em Barrett (1998), este incluindo na discussão as chamadas normas sociais e o ecumenismo de algumas religiões. 
O valor de um recurso costuma ser considerado como composto de três parcelas: valor de uso (direto e indireto), valor de opção e valor de existência (Mitchell \& Carson, 1989; Pearce \& Turner, 1989; Shogren \& Crocker, 1990; Winpenny, 1993). O valor de uso é atribuído pelos indivíduos ante a oportunidade de consumo imediato. $O$ valor de opção é o máximo que um indivíduo averso a risco dispõe-se a pagar para deter a opção de contar no futuro com um recurso (preço de opção). É uma espécie de prêmio de risco por futuro acesso a um recurso, tanto para si como para gerações futuras. $O$ valor de existência, conceito cuja introdução é creditada a Krutila (1967), é o atribuído por indivíduos que não consomem o recurso, tampouco vislumbram a oportunidade de fazê-lo, mas obtêm satisfação pelo fato de o bem existir para outras pessoas no presente ou no futuro; é um valor tipicamente intrínseco aos indivíduos e somente aferivel, se isto for possível, por valoração contingente. $O$ valor de existência implica em dissociar do recurso sua natureza utilitarista, levantando-se alguns motivos presumiveis para sua ocorrência: (i) herança às gerações futuras; (ii) benevolência (doação); (iii) simpatia por animais e pessoas; (iv) interrelação ambiental; e (v) responsabilidade ambiental (Marques \& Comune, 1997). Porém, sem entrar na discussão, essas classificações também são passiveis de reparos (More et al., 1996).

A dificuldade de se aferir o valor de bens não transacionados em mercado vem motivando, basicamente a partir da década de setenta e com grande desenvolvimento metodológico na década seguinte e na atual, um grande número de pesquisas e ensaios sobre metodologia e técnicas de estimativa desses valores.

Sob a teoria neoclássica, o valor atribuido por um indivíduo pode ser medido por sua "disposição a pagar" (do inglês willingness to pay - WTP) pela obtenção dos serviços de determinado bem ou por sua "disposição a aceitar" compensação (do inglês wilingness to accept - WTA) pela renúncia do mesmo. Dos trabalhos pioneiros sobre valoração de bens naturais, a maioria dedicou- 
se a estimar valores de bens públicos, principalmente para recreação ao ar livre. A primeira técnica utilizada ficou conhecida como custo de viagem, segundo Bishop \& Heberlein (1979), seguindo-se diversos outros métodos. Os principais métodos utilizados para estimar o valor de bens ambientais são apresentados e discutidos no capítulo 2 .

\subsection{Objetivos deste trabalho}

O objetivo geral deste trabalho é estimar o valor monetário atribuído pela sociedade à reposição e preservação de matas ciliares na bacia do rio Corumbataí, SP.

Como objetivos especificos, tem-se:

1) estimar a probabilidade de ocorrência, num mercado hipotético, de valores não-negativos que a população da região do estudo esteja disposta a pagar pelo aumento da qualidade ambiental representada pela reposição de matas ciliares;

2) estimar, por generalização do valor médio, o valor total atribuído pela população da área de estudo ao recurso ambiental considerado;

3) associar o valor da disposição a pagar a características sócioeconômicas das pessoas.

Como contribuição representada por este trabalho, espera-se:

1) fornecer aos responsáveis pela formulação de políticas públicas subsídios para a tomada de decisões sobre o recurso ambiental em análise, através do grau de respaldo popular ao projeto;

2) oferecer à sociedade da região abrangida pelo estudo elementos de negociação entre seus segmentos e organizações. 


\subsection{Procedimentos}

No capítulo 2, apresenta-se uma breve revisão da teoria de mercado e suas adaptações para atribuição de valor a recursos ambientais, procurandose confrontar posições favoráveis e contrárias a cada técnica ou metodologia, incluindo técnicas de levantamento dos dados ou, conforme o caso, assinalar os procedimentos mais largamente aceitos nos trabalhos científicos consultados.

Como resultado dessa discussão, propõe-se, no capítulo 3, o modelo a ser adotado e apresenta-se a caracterização da área de estudo. O capítulo 4 apresenta os resultados obtidos e sua interpretação, reservando-se o capítulo 5 para um resumo do trabalho, conclusões finais e sugestões. Ao final, encontram-se a bibliografia consultada e apêndices. 


\section{BASE TEÓRICA}

Das diversas abordagens sobre o problema de valoração de recursos ambientais ou seus serviços, não transacionados em mercado, as mais largamente utilizadas são uma extensão dos princípios de maximização do bem-estar via análise de benefício-custo, necessitando-se, para isso, da expressão dos valores monetários, observados ou inferidos. Se isto é possivel, a estimativa dos impactos é imediata, via integração dos valores (Gregory \& Slovic, 1997).

Os conceitos e derivações do modelo neoclássico de bem-estar estão suficientemente generalizados, não se julgando necessário repeti-los passo a passo neste trabalho. $O$ que se apresentará a seguir são as passagens consideradas essenciais ao acompanhamento do raciocínio aqui desenvolvido. A partir do modelo tradicional para bens de mercado, fazem-se, com base na literatura disponivel, as adaptações necessárias para contemplar bens que não são transacionados em mercados ${ }^{10}$.

O pressuposto fundamental é que cada mulher ou homem (indivíduo, no jargão da área), às vezes considerando-se a família como indivíduo econômico, é perfeitamente capaz de avaliar seu grau de satisfação (utilidade) derivado dos níveis de consumo de bens e serviços. A função disso resultante não é observável por outras pessoas, a não ser indiretamente. Admita-se que uma pessoa $i$, com renda $r$, consome as quantidades $\mathbf{x}=\left[x_{j}\right]$ dos serviços de $n$

\footnotetext{
${ }^{10}$ Sobre o assunto, ver, por exemplo, Freeman (1979), Hanemann (1984), Johansson (1987), Hanemann (1991), Ribaudo \& Hellerstein (1992), Belluzzo Jr. (1995), entre outros.
} 
27.

bens $(j=1, \ldots, n)$, cujos preços respectivos são dados pelo vetor $p=\left[p_{j}\right]$ e visa maximizar sua utilidade $u=u(\mathbf{x})$ limitada por sua restrição orçamentária $r=\mathbf{p}^{\mathbf{x}} \mathbf{x}$ (onde 0 apóstrofo indica transposição matricial). Formalizando, o indivíduo objetiva maximizar

$$
u=u(\mathbf{x})
$$

sujeito a $\mathbf{p}^{\prime} \mathbf{x}-r=0$. A conhecida solução do problema resulta nas funções de demanda ordinária individual

$$
x_{j}=x^{j}(\mathbf{p}, r)
$$

As $n$ equações de ( 2 ) são formalmente passiveis de observação a campo. Substituindo-se ( 2 ) em ( 1 ), tem-se a função indireta de utilidade:

$$
u=v(\mathbf{p}, r)=u[x(\mathbf{p}, r)]
$$

O dual do problema, minimizar o dispêndio $r=p^{\prime} x$ sujeito a um dado nível $u^{\star}$ de utilidade, resulta no sistema de equações de demanda compensada da teoria hicksiana

$$
h_{j}=h^{j}\left(\mathbf{p}, u^{\star}\right)
$$

e na função dispêndio individual

$$
d\left(\mathbf{p}, u^{*}\right)=\Sigma p_{j} h^{j}(\mathbf{p}, u)=r
$$

\subsection{Disposição a pagar e disposição a aceitar compensação}

Por simplificação, considere-se que 0 indivíduo consome $x_{1}$ de um determinado bem e $x_{2}$ de um conjunto formado por todos os demais bens, exceto o primeiro. Os respectivos preços são $p_{1}$ e $p_{2}=1$, isto é, os "demais bens" são tomados como o numerário do sistema. Com auxílio da Figura 3 , 
num dado momento o indivíduo está consumindo $x_{1}^{0}$ e desfruta do nível $u^{0}$ de utilidade. Está, portanto, no ponto A da figura. Se ocorre, por exemplo, uma redução no preço $\left(p_{1}^{1}<p_{1}^{0}\right)$, tudo o mais constante, o ponto de máxima satisfação do consumidor desloca-se de A para B, com a utilidade individual passando de $u^{0}$ para $u^{1}$, em nível mais alto.

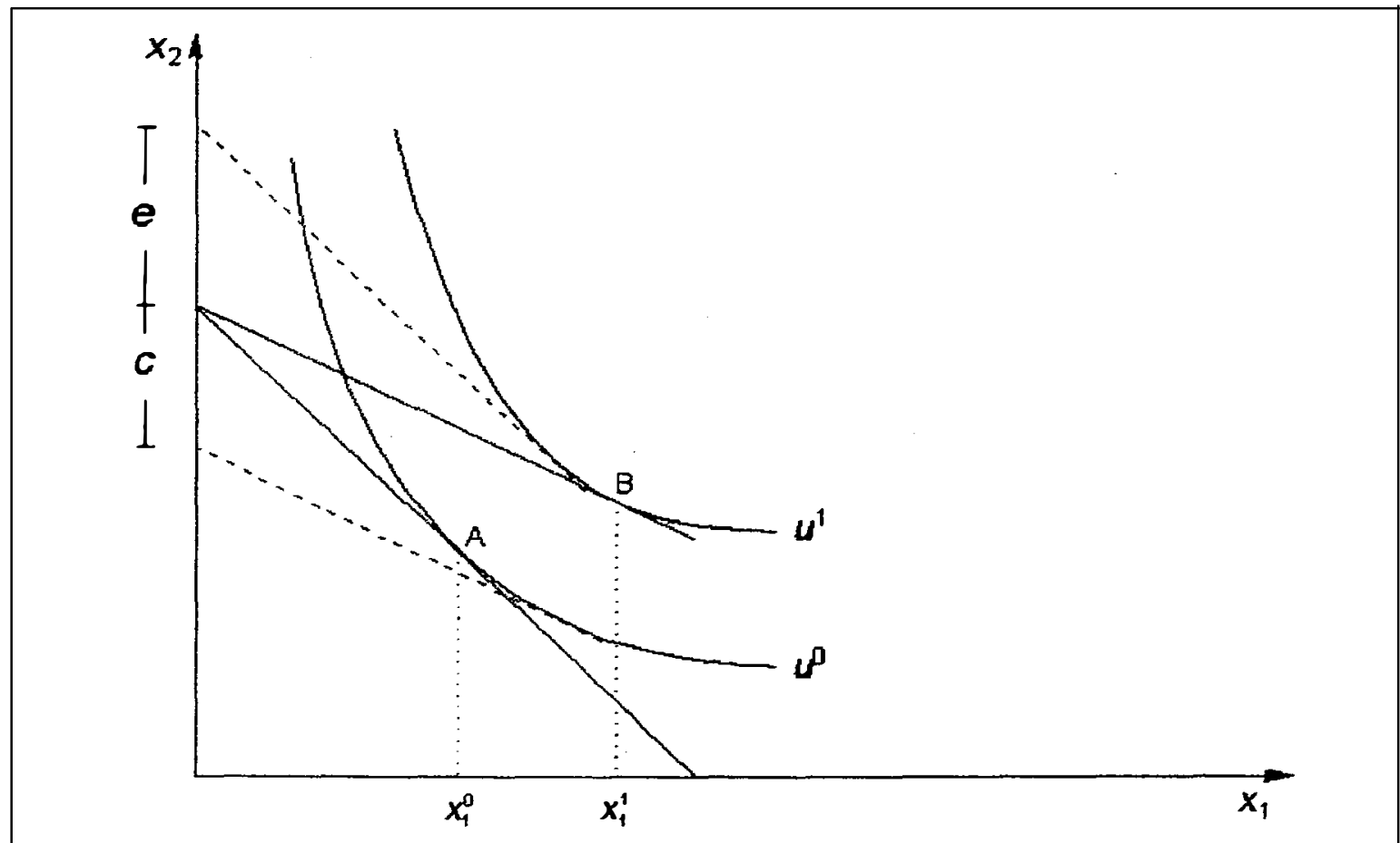

Figura 3. Variação equivalente (e) e variação compensatória $(c)$ da renda no caso de uma redução no preço de $x_{1}$.

Fonte: adaptado de Ribaudo \& Hellerstein (1992).

Se há uma variação em $\rho_{1}$, isto provoca um efeito não só na quantidade consumida de $x_{1}$, mas também na renda disponível para consumo de $x_{2}$. Da teoria hicksiana: variação equivalente da renda (e, na Figura 3) é definida como a quantidade de renda que se terá de dar ao consumidor, ao preço $p_{1}^{0}$, para deixá-lo tão bem quanto estaria ao preço $p_{1}^{1}$, isto é, na curva de indiferença $u^{1}$. Variação compensatória (c, na Figura 3), por sua vez, é a 
quantidade de renda de que o consumidor deve abrir mão para deixá-lo tão bem quanto antes da variação do preço, isto é, na curva de indiferença $u^{\circ}$.

A medida de $c$ pode ser interpretada como a disposição do indivíduo a pagar $(p)$ para aumentar seu nível de consumo de $x_{1}$, mantendo-se no mesmo patamar $u^{0}$ de indiferença. A medida de e é interpretada como a disposição a aceitar compensação (a) para abrir mão de parte de seu consumo possivel de $x_{1}$, mas usufruindo utilidade mais alta $\left(u^{1}\right)$. Raciocínio semelhante, mas em sentido inverso, pode ser feito quando se analisa a elevação do preço de um bem ou serviço.

Ao lado da variação no excedente do consumidor marshalliano $(m)$, as medidas das variações equivalente e compensatória da renda são freqüentemente aceitas como estimativas adequadas do efeito no bem-estar provocado pela variação de um dos preços. No entanto, os valores verdadeiros de $c$ e e não são observáveis diretamente, ao passo que $m$ pode ser deduzido da função de demanda ordinária.

Formalizando os conceitos de variação compensatória e variação equivalente, no caso de uma redução no preço de $x_{1}$, e lembrando a eq.( 3 ), que dá a expressão para a utilidade indireta, 0 indivíduo "concorda" com a alteração econômica (redução do preço) se sua máxima variação compensatória seja tal que

$$
v\left(p_{1}^{1}, r-c\right)=v\left(p_{1}^{0}, r\right)
$$

Por outro lado, sua variação equivalente tem seu valor mínimo dado por

$$
\gamma\left(\rho_{1}^{1}, r\right)=v\left(p_{1}^{0}, r+e\right)
$$

Atribui-se a Willig (1974) a construção do modelo que permite, a partir do valor observável do excedente do consumidor, inferir os valores nãoobserváveis da variação equivalente e da variação compensatória. Estas duas 
medidas são consideradas teoricamente corretas para se aferir o impacto no bem-estar causado pela alteração de um determinado preço. $O$ autor impôs as seguintes limitações: a) $\left|\bar{\eta} m / 2 r^{0}\right| \leq 0,05$; b) $\left|\underline{\eta} m / 2 r^{0}\right| \leq 0,05$ e c) $\left|m / r^{0}\right| \leq 0,9$, onde $\bar{\eta}$ e $\underline{\eta}$ são, respectivamente, o maior e o menor valor da elasticidaderenda da demanda no intervalo considerado, lembrando que $r$ é a renda individual, $c$ é a variação compensatória, $e$ é a variação equivalente e $m$ é a variação no excedente do consumidor $\left(m<0\right.$ se $p_{1}^{1}<p_{1}^{0}$ e $m>0$ em caso contrário). Partindo das relações

$$
\begin{aligned}
& \frac{\underline{\eta}|m|}{2 r^{0}} \leq \frac{c-m}{|m|} \leq \frac{\bar{\eta}|m|}{2 r^{0}} \text { e } \\
& \frac{\underline{\eta|m|}}{2 r^{0}} \leq \frac{m-e}{|m|} \leq \frac{\bar{\eta}|m|}{2 r^{0}}
\end{aligned}
$$

e considerando que, usualmente, $\bar{\eta} \approx \underline{\eta} \approx 1$ e que a relação $|m| / \Gamma$, na maioria das aplicações, é "muito pequena", então, se $\bar{\eta}|m| / 2 r^{0}$ e $\underline{\eta}|m| / 2 r^{0}$ são "pequenas o suficiente" (próximas de zero), pode-se tomar os valores da variação compensatória e da variação equivalente como muito próximos do valor do excedente do consumidor. Em outros termos, $c \approx m \approx e$. No entanto, se há efeito-renda, $c$, e e $m$ assumem valores diferentes. No caso do aumento de um preço, a única forma de satisfazer as eq. ( 8 ) e (9) é com $c>m>e$.

Ainda com base em Willig (1976), uma variação no preço provoca o efeito ilustrado na Figura 4, em que $x^{1}$ simboliza a demanda ordinária e $h^{1}$ a demanda compensada pelo bem $x_{1}$. Neste caso, a variação compensatória (c) corresponde à área $p_{1}^{0} p_{1}^{1} D B$ da Figura 4.a, a variação equivalente (e) corresponde à área $p_{1}^{0} p_{1}^{1} A C$ e o excedente do consumidor $(m)$ à área $p_{1}^{0} p_{1}^{1} A B$. Portanto, se há um aumento do preço, $c>m>e$. Por analogia, na Figura 4.b 
(representando uma redução do preço), $c$ corresponde à área $p_{1}^{1} p_{1}^{\circ} A C, e$ à área $\rho_{1}^{1} \rho_{1}^{\circ} D B$ e $m$ à área $p_{1}^{1} p_{1}^{\circ} A B$. Neste caso, $c<m<e$.

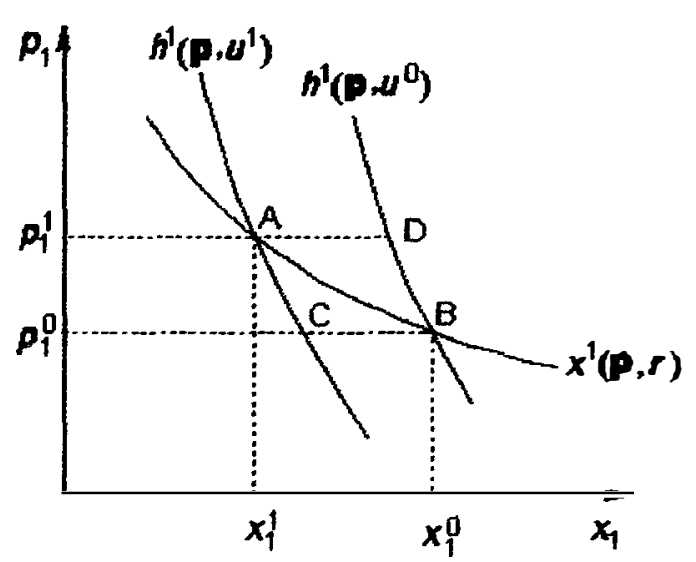

(a)

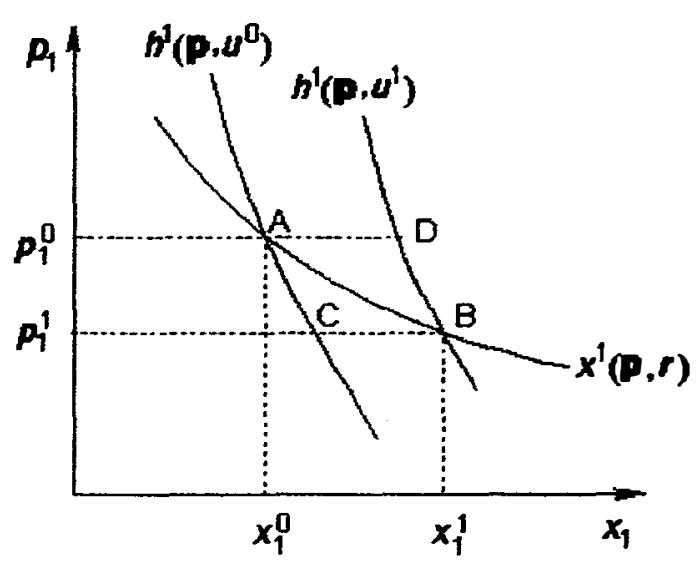

(b)

Figura 4. Demanda ordinária e demanda compensada.

Fonte: (a) baseado em Willig (1976); (b) por analogia com (a).

Até aqui, considerou-se o efeito no bem-estar de uma variação de preço. No entanto, não é raro que a análise de benefícios e custos trate de projetos em que a variação ocorre nas quantidades, sem necessariamente afetar preços ou renda. Deve-se a Randall \& Stoll (1980) o desenvolvimento de um modelo para se medir o impacto no bem-estar de variação no nível de consumo de bens, serviços e "amenidades". Neste caso, recomenda-se utilizar os termos excedente compensatório e excedente equivalente em lugar de variação compensatória e variação equivalente ${ }^{11}$.

Considere-se uma alteração $\Delta x_{1}=x_{1}^{1}-x_{1}^{0}>0$. Se os níveis de $x_{1}$ podem ser escolhidos pelo consumidor, isto é, se é um bem perfeitamente divisivel, negociado num mercado "infinitamente grande" e sem custos de transação, os autores demonstram que $p=m=a$, em valores absolutos,

\footnotetext{
${ }^{11}$ Ver, também, Brookshire et al. (1980) e Bishop \& Woodward, 1995.
} 
lembrando-se de que $p$ é a medida da disposição a pagar, a é a medida da disposição a aceitar compensação e $m$ a medida do excedente do consumidor. Por outro lado, se $x_{1}$ é um bem indivisivel ou de consumo não-excludente, então $\Delta x_{1}>0$ faz com que, em valores absolutos, $p<m<a$.

Bens não-divisiveis ou de consumo não-excludente sugerem bens de consumo coletivo, ou bens públicos, na denominação de alguns autores. $O$ tratamento teórico da inclusão do consumo de bens de consumo coletivo como argumento da função utilidade individual remonta a Samuelson (1954). Para o autor, o sistema de preços concorrencial ("descentralizado") não é capaz de estabelecer os níveis ótimos de suprimento desses bens, sendo necessário tentar outros mecanismos, como "votação" ou "sinalização" pela sociedade (aspas no original em inglês). $O$ aporte de recursos para a oferta de bens de consumo coletivo seria dependente do volume de impostos e taxas pagos pelos indivíduos.

A partir deste ponto, adota-se uma pequena alteração na notação. Considerem-se dois conjuntos de bens consumidos pelo indivíduo: um bem $q$, representando um conjunto de serviços de recursos ambientais (um bem genérico "qualidade ambiental", por exemplo), determinado exogenamente, e $n$ bens de mercado $x_{j}(j=1, \ldots, n)$. A função utilidade então é dada por

$$
u=u(\mathbf{x}, q)
$$

com $\partial u / \partial x_{j}>0$, para todo $j$, e $\partial u / \partial q>0$. Por derivação análoga à das eq.( 1 ) a ( 3 ), tem-se que a demanda ordinária é dada por

$$
x_{j}=x^{j}(\mathbf{p}, q, r)
$$

e a utilidade indireta é dada por

$$
u=v(\mathbf{p}, q, r)
$$


Por simplificação, considere-se que todos os bens $x_{j}$ são tomados como uma cesta de consumo de proporções fixas. Admita-se, então, uma situação inicial em que 0 indivíduo está usufruindo o nível de utilidade $u^{0}=u\left(q^{0}, x^{0}\right)$, correspondente ao ponto $\mathrm{A}$ da ilustração apresentada na Figura 5 , quando um choque resultante de uma dada política altera o nível de $q$, de tal forma que $\Delta q=q^{1}-q^{0}>0$.

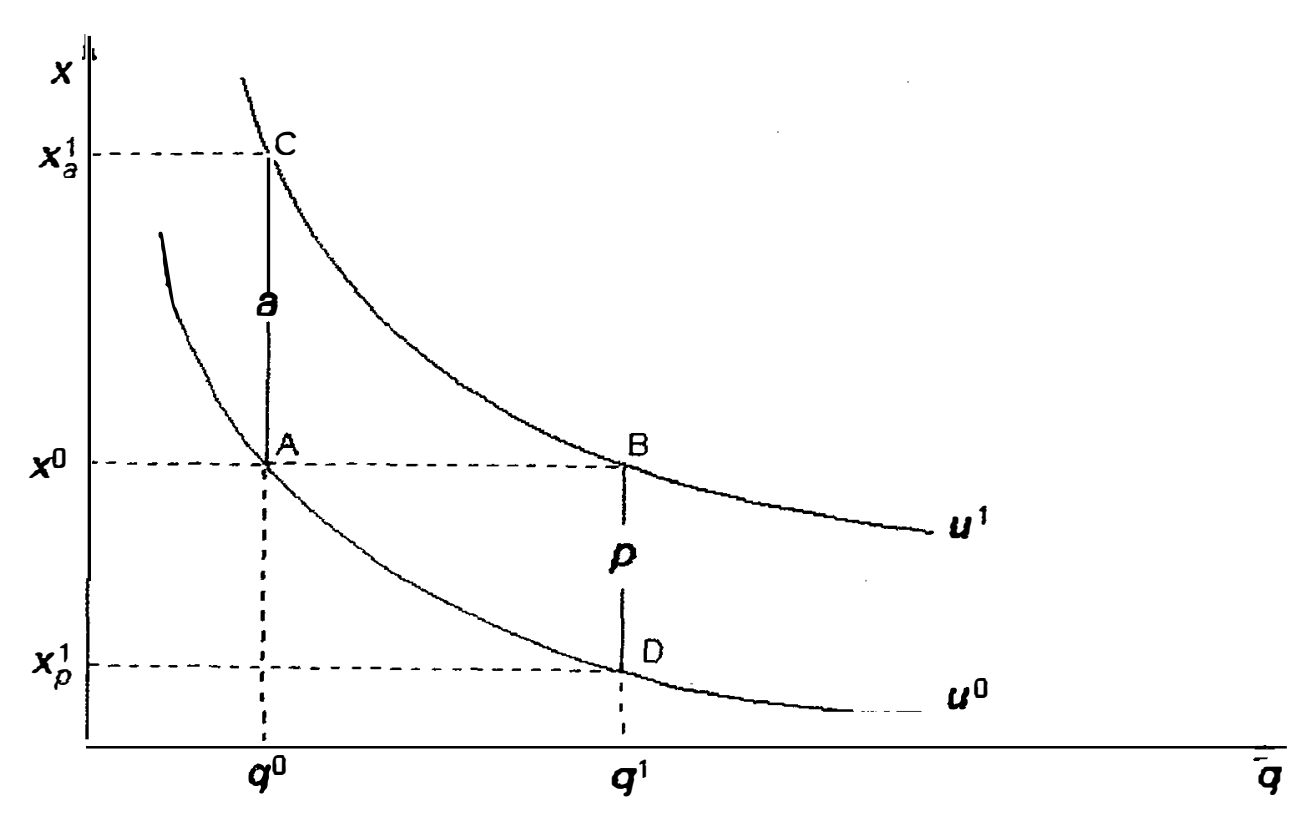

Figura 5. Disposição a pagar ( $p$ ) e disposiçāo a aceitar compensação (a).

Fonte: adaptado de Loomis et al. (1998).

Se $q$ é um bem público, de consumo não-excludente, $\Delta q$ ocorre sem ônus para o indivíduo e o nível de consumo independe de sua escolha, então a pessoa atinge o nivel de utilidade $u^{1}=u\left(q^{1}, x^{0}\right)$, situando-se no ponto B. Notese que, neste caso, não faz sentido falar-se em linha orçamentária (Randall \& Stoll, 1980). Fazendo-se $p_{x}=1$ (numerário do sistema), o excedente compensatório, ou disposição a pagar $(p)$, corresponde a $\overline{\mathrm{BD}}$, isto é, ao valor da renda, em termos de $x$, de que 0 indivíduo se dispõe a abdicar para permanecer no nivel $u^{0}$ de utilidade, mas aumentando seu consumo para $q^{1}$. O 
excedente equivalente, ou disposição a aceitar compensação (a), corresponde a $\overline{\mathrm{AC}}$, isto é, ao valor, em termos de $x$, reivindicado pela pessoa para manter seu consumo em $q^{0}$ e atingir o nivel $u^{1}$ de utilidade. Se o excedente equivalente se concretiza, a pessoa passa a situar-se no ponto $C$, que corresponde a $u^{1}=u\left(q^{0}, x_{a}^{1}\right)$. Se o excedente compensatório é efetivamente cobrado do indivíduo, sua combinação de consumo é dada pelo ponto $D$, isto é, onde $u^{0}=u\left(q^{1}, x_{p}^{1}\right)$.

Seguindo-se o raciocínio de Hanemann $(1984 ; 1991)^{12}$, dada uma variação $\Delta q=q^{1}-q^{0}>0$, mantendo-se a renda e os preços constantes, tem-se que a utilidade passa de $u^{0}$ para $u^{1}>u^{0}$. Lembrando a eq.( 12$)$, tem-se $u^{0}=v\left(\mathbf{p}, q^{0}, r\right)$ e $u^{1}=v\left(\mathbf{p}, q^{1}, r\right)$. Pressupondo-se que 0 indivíduo se dispõe a pagar $\rho$ pela alteração se $u^{1} \geq u^{0}$, sua máxima disposição a pagar é dada por

$$
v\left(\mathbf{p}, q^{1}, r-p\right)=v\left(\mathbf{p}, q^{0}, r\right)
$$

De maneira análoga, a compensação minima aceitável é dada por

$$
v\left(\mathbf{p}, q^{1}, r\right)=v\left(\mathbf{p}, q^{0}, r+a\right)
$$

Com base na função dispêndio $r=d\left(\mathbf{p}, q, u^{*}\right)$, a um dado nível de utilidade resulta que

$$
\begin{aligned}
& \rho=d\left(\mathbf{p}, q^{0}, u^{0}\right)-d\left(\mathbf{p}, q^{1}, u^{0}\right) \quad \mathrm{e} \\
& a=d\left(\mathbf{p}, q^{0}, u^{1}\right)-d\left(\mathbf{p}, q^{1}, u^{1}\right)
\end{aligned}
$$

Das eq. ( 15 ) e ( 16 ), conclui-se que $0<p<r$ e $a \geq 0$.

\footnotetext{
${ }^{12}$ A respeito dessas deduções, ver também Freeman (1979), Boyle \& Bishop (1988) e Whitehead (1995).
} 
A precisão dos resultados da análise de benefícios e custos sociais de um projeto depende, metodologicamente, da proximidade ou não dos valores estimados de a e $p$, isto é, se a razão entre a e $p$ é próxima de um ou não, e que fatores afetam essa relação.

\subsection{Diferenças entre disposições a pagar e a aceitar compensação}

Para Krutila (1967), o uso de recursos naturais, sob a ótica empresarial, é convertido no valor presente do fluxo de receitas líquidas dos usos alternativos. No caso de políticas que visam destinar recursos para consumo público, o autor assinala que os valores estimados da disposição a pagar (do público beneficiado) podem ser significativamente menores que o montante necessário para compensar os indivíduos que abdicam do aumento no uso do recurso em questão. Neste caso, torna-se muito difícil, senão impossivel, determinar a eficiência alocativa do mercado. Isto porque, se os ganhadores no processo econômico visam maximizar seus lucros e os perdedores visam minimizar seus prejuizos, há a tendência de que a disposição a aceitar compensação seja maior que a disposição a pagar pelo mesmo recurso, bem ou serviço (Harris \& Brown, 1992).

Utilizando como experimento o "mercado" de licenças para caça de gansos selvagens expedida em 1978 numa região dos EUA, Bishop \& Heberlein (1979) verificaram ser significativamente diferentes os valores da disposição a pagar, da disposição a aceitar compensação e do custo de viagem (ver seção 2.3.1) dos praticantes de tal atividade. Concluíram que os valores de $p$, "distorcidos para baixo", e de a, "distorcidos para cima", podem ser interpretados como os limites inferior e superior, respectivamente, do "valor verdadeiro" do bem em análise na curva de demanda. Segundo Mitchell \& Carson (1989), pode acontecer de o valor verdadeiro jamais ser conhecido. Da análise feita por esses autores de uma série de relatos publicados de 
experimentos especialmente desenhados para tal fim, na grande maioria dos casos (mais de quatro quintos), a disposição a pagar situou-se entre $70 \%$ e $90 \%$ do verdadeiro valor, com os casos extremos sendo de $61 \%$ e $96 \%$. Ainda os mesmos autores, analisando dezenas de trabalhos publicados, concluíram que a disposição a pagar é a melhor medida para se estimar o valor de aumento, ou de se evitar a redução, de serviços ambientais. Em 23 trabalhos compulsados por Brown \& Gregory (1999), a disposição a aceitar compensação foi sempre maior que a disposição a pagar pelo mesmo recurso. Ocorreram cinco casos com valores entre uma e duas vezes, treze entre duas e cinco, três entre cinco e dez e dois acima de dez vezes. Essa disparidade, segundo os autores, é causada por: (i) efeitos renda e substituição; (ii) custos de transação, se estes afetarem diferentemente provedores e usuários; (iii) efeitos do ganho vislumbrado, com os provedores tendendo a ver os valores mais altos e os usuários tendendo a ver os valores mais baixos, e (iv) outras, como legitimidade, responsabilidade, nível de conhecimento e aversão ao risco.

A existência de substitutos reduz a disparidade entre a e $p$, segundo Hanemann (1991). O autor demonstrou que, se pelo menos um bem $x_{k}$ é substituto perfeito de $q$, então $a=p$. No extremo oposto, se entre $q$ e $x_{j}$, para todo $j$, a relação de substituição é nula, então há um limite superior para a disposição a pagar por $\Delta q$, determinado pela renda, mas a disposição a aceitar compensação pode não ter um limite superior, isto é, pode tender ao infinito. Mantendo-se a renda constante, quanto menor a possibilidade de substituição, maior a disparidade entre $p$ e a. No caso de qualidade ambiental, no entanto, a definição de possibilidade de substituição é uma tarefa extremamente complexa, senão impossível (Krutila, 1967; Adamowicz et al., 1993). A possibilidade de substituição entre os bens pode falhar no caso de alguns itens, como qualidade da água, qualidade do ar e manutenção de espécies vivas, entre outros (Gowdy \& O'Hara, 1995). 
Essas conclusões soam como uma forte advertência contra estimativas do valor de serviços ambientais através da disposição a aceitar compensação e em favor de inferências do valor da disposição a pagar, em que pesem as restrições que também se apresentam contra esta medida. Se o critério a ser seguido é dar um caráter mais conservador às estimativas a serem obtidas (grosso modo, valores mais próximos do limite inferior), a disposição a pagar tende a ser a medida mais apropriada, mesmo porque soa pouco verossímil imaginar-se uma situação em que o indivíduo deva, ou que aceite, ser compensado pelo fato de não haver aumento na disponibilidade de determinados serviços ambientais. Essa dúvida, no entanto, praticamente desaparece quando o projeto provoca redução do acesso do indivíduo a determinados recursos, quando a medida a ser buscada é a disposição a aceitar compensação. No caso de aumento da qualidade ambiental, Ribaudo \& Hellerstein (1992) indicam o excedente compensatório como a medida mais adequada, e o excedente equivalente no caso em que há redução, real ou iminente, do nivel de qualidade ambiental. A disposição a pagar vem sendo considerada uma estimativa do limite inferior do excedente hicksiano (Champ et al., 1997). Esta variante será tomada como eixo central deste trabalho.

\subsection{Métodos de valoração ambiental}

Valor, no sentido de medida monetária de um bem ou serviço, tem conceituação variável com as doutrinas econômicas, gerando de discordâncias pontuais a antagonismos inconciliáveis. Não se pretende, neste trabalho, enveredar pela discussão dos diferentes conceitos. $O$ que se propõe é adotar $O$ modelo neoclássico, com as adaptações necessárias ao trato de serviços de bens não transacionados em mercado, admitindo - sem pretender defini-las diferenças de atitudes entre o "homo economicus" e o "homo politicus" mencionados por Nyborg (2000) e as lembradas nos trabalhos, entre outros, de 
38.

Akerlof \& Dickens (1982), Söderbaum (1994), Ajzen et al. (1996) e Sagoff (1998).

No modelo considerado, valor é um montante em dinheiro que só ocorre entre pessoas, envolvendo um bem ou serviço, se há interação resultante das preferências individuais, conforme as conhecidas teorias da demanda e da oferta. Bens negociados em mercado têm seu valor sinalizado pelos respectivos preços. Os preços variam de acordo com a percepção de cada indivíduo e são expressos pela disposição a pagar pelos serviços do bem ou pela disposição a aceitar compensação pela renúncia dos mesmos (Mitchell \& Carson, 1989; Pearce \& Turner, 1989). A satisfação obtida pelo consumidor depende das características dos bens e serviços consumidos, cujos atributos podem ter diversos significados para a pessoa e podem variar de acordo com as diferentes combinaçōes de consumo (Lancaster, 1966).

A decisão sobre a aplicação de recursos escassos em projetos alternativos com base na estimativa da relação entre benefícios e custos é tradicional na análise econômica. É um instrumento típico da economia positiva, em que predomina o princípio de soberania do consumidor, com prioridade para a eficiência econômica, sem mecanismos para captar aspectos distributivistas da riqueza gerada (Mitchell \& Carson, 1989). Bens ambientais, entretanto, nem sempre podem ter seus preços expressos pelo mercado e acabam sendo desconsiderados ou recebem ponderação inadequada nos processos tradicionais de análise.

O valor monetário total de um recurso costuma ser decomposto de diversas formas, utilizando-se terminologia variável, mas a essência dos conceitos se mantém. Por exemplo, Mitchell \& Carson (1989) consideram o valor total composto pelo valor de acesso e pelo valor de existência, sendo o valor de acesso representado pelo valor de uso (direto e indireto) e pelo valor de opção. $O$ valor de opção é uma espécie de prêmio de risco por acesso futuro a um recurso desejado (Shogren \& Crocker, 1990) e reflete a decisão 
39.

sob incerteza. Assim, de acordo com Mitchell \& Carson (1989), a eq.( 10 ) seria reescrita:

$$
u=u(\mathbf{x}, q)=w[f(\mathbf{x}, q), g(q)]
$$

onde, no segundo membro, o primeiro termo refere-se ao valor de acesso e o segundo termo ao valor de existência.

Algumas correntes de pensamento advogam princípios não totalmente cobertos pela teoria neoclássica, como a defesa dos chamados valores intrínsecos, interpretados como inerentes ao próprio recurso, não sendo relacionados à atividade humana, como expresso pela defesa que alguns autores fazem do direito à existência de espécies e habitats (White \& Lovett, 1999). Para este tipo de enfoque, preconiza-se que a análise leve em conta fatores como reversibilidade, incerteza e possibilidade de substituição entre bens ambientais e de mercado (Popp \& Hoag, 1998).

Pelo fato de não se conseguir obter o preço de determinados serviços ambientais diretamente da observação de mercado, as estimativas de seus valores são obtidas por métodos alternativos ${ }^{13}$, que podem ser agrupados em três categorias principais: (i) baseados no principio da complementaridade fraca; (ii) inquirição direta das pessoas sobre sua disposição a pagar por alterações no ambiente, efetivas, iminentes ou hipotéticas (Mitchell \& Carson, 1989; Pearce \& Turner, 1989; Bishop \& Woodward, 1995; Crutchfield et al., 1995), e (iii) baseados em relações físico-químicas do ambiente, do tipo doseresposta ou função dano (Mitchell \& Carson, 1989; Pearce \& Turner, 1989). Esta terceira alternativa exige a identificação e a formulação funcional das interrelações ambientais, o que, com o conhecimento atualmente disponivel, só pode ser atendido em parte. Envolve métodos que não se relacionam

\footnotetext{
${ }^{13} \mathrm{Em}$ todos os métodos citados nos itens 2.3.1 e 2.3.2, está implícita a existência de uma função de demanda pelos serviços ambientais considerados.
} 
diretamente com os princípios de soberania do consumidor, e não se antevê possibilidade de sua adoção neste trabalho.

\subsubsection{Complementaridade fraca}

Lembrando a eq.( 11 ), as funções de demanda ordinária do indivíduo são dadas por $x_{j}=x^{j}(p, q, r)$. Se o consumo dos serviços de um determinado bem $x_{k}$ é complementar a $q \mathrm{e}$, quando $x_{k}=0$ implica em utilidade marginal de $q$ igual a zero, então diz-se que há complementaridade fraca entre $x_{k}$ e q. Assim, a aplicação do princípio da complementaridade fraca em métodos de valoração ambiental depende da estimativa da demanda de bens de mercado relacionados. Se as pessoas podem escolher a quantidade $q$, então seu preço pode ser estimado indiretamente pelo consumo de bens de mercado complementares (Bishop \& Heberlein, 1979). Os métodos indiretos de estimativa dos valores de serviços ambientais que se utilizam de indicadores de mercado baseiam-se nas preferências reveladas das pessoas, isto é, na observação de "como agem" (White \& Lovett, 1999), e captam apenas a parte de natureza privada do recurso ambiental (Freeman, 1979; Smith, 1993) e não o valor de outras funções ambientais, como biodiversidade, valor cênico, valor científico e cultural, importância do habitat e outros.

Os principais métodos de estimação do preço de serviços ambientais baseados no princípio da complementaridade fraca são a diferenciação do valor de imóveis, o gasto com medidas preventivas ou corretivas e o custo de viagem (Crutchfield et al., 1995). Na terminologia da área, valores atribuídos a recursos ambientais por causa de seus atributos são também chamados de preços hedônicos.

A diferenciação do preço dos imóveis refere-se à estimativa do valor imputável à qualidade ambiental representado pela diferença entre o preço de propriedades semelhantes dentro ou nas vizinhanças de locais "com" e "sem" o 
atributo considerado (Freeman, 1979). A grande dificuldade é isolar o atributo em análise dos demais fatores que resultam no preço final do imóvel.

O método que considera o gasto com medidas preventivas ou corretivas associa o valor atribuído ao recurso ambiental a dispêndios com substitutos ou com medidas corretivas em relação a dado nivel de qualidade ambiental desejado (Freeman, 1979). Por exemplo, a disposição a pagar pela qualidade da água de consumo humano pode ser estimada pelos gastos com água engarrafada, com fervura da água "de torneira", com adição de produtos germicidas, com a compra e manutenção de utensílios (filtros, velas) e com outras despesas semelhantes (Carpentier \& Vermersch, 1999). Um exemplo de aplicação deste método para condições brasileiras pode ser visto no trabalho de Rosado (1998).

O custo de viagem, segundo Freeman (1979), é passivel de aplicação a locais em que há um fluxo controlado (ou controlável) de pessoas, num dado intervalo de tempo, que consomem os serviços de um bem público. $\mathrm{Na}$ definição de Mitchell \& Carson (1989), se o recurso não é livremente negociado em mercado, mas seu consumo tem algum poder de exclusão, isto é, se é possivel cobrarem-se entradas, licenças e assemelhados, o recurso é considerado "quase-privado". Geralmente por amostragem, os usuários do serviço são inquiridos sobre distância percorrida, gastos efetuados com viagem e alojamento, pagamento de entradas e licenças, despesas com materiais, munição, alimentação e coisas do gênero. Mediante tratamento estatístico adequado, os dados podem ser generalizados para toda a demanda pelo local (Freeman, 1979; Randall, 1987; Bergstrom et al., 1990b). O método de custo de viagem, se aplicado a locais comparáveis, mostra consistência entre o preço relativo, a elasticidade-renda e o excedente do consumidor por unidade de uso. A modelagem da pesquisa afeta essas medidas econômicas. Em experimentos controlados, o modelo delineia razoavelmente bem as preferências dos consumidores (Smith, 1993). Um exemplo da aplicação do 
método de custo de viagem a uma situação brasileira é a dissertação de mestrado de Casimiro Filho (1995).

Resenha em publicação de Carson et al. (1996) contabiliza 616 situações em que as preferências reveladas embasaram estimativas de preços de serviços de bens quase-privados, de acordo com o método utilizado: (i) custo de viagem num único local: 295; (ii) custo de viagem em locais múltiplos: 183; (iii) preços hedônicos: 62; (iv) comportamento defensivo ou corretivo: 28; (v) definição de mercados existentes ou simulados: 48. Dessas avaliações, 432 referem-se a recreação ao ar livre, 163 a "amenidades" ambientais e 21 a riscos à saúde.

Pelas características da área deste estudo e do recurso ambiental objeto da análise (matas ciliares em propriedades privadas), não se considera viável a aplicação de métodos que dependam da observação das preferências reveladas.

\subsubsection{Valoração contingente}

O método de valoração contingente foi desenvolvido como ferramenta auxiliar da análise benefício-custo (Randall, 1997), procurando captar aqueles valores que os analistas costumam arrolar como benefícios e custos secundários ou intangiveis (ver, por exemplo, Gittinger, 1972). Métodos que analisam dados extraídos de mercados hipotéticos são potencialmente capazes de captar o valor total atribuído por uma pessoa a um determinado recurso, bem ou serviço, mas dificilmente podem decompô-lo em seus valores de uso e de não-uso (Mitchell \& Carson, 1989; Bishop \& Woodward, 1995; Crutchfield et al., 1995; White \& Lovett, 1999), isto é, fazem um julgamento holístico do serviço ambiental em análise. Freqüentemente, são a única alternativa disponivel para se estimarem os benefícios de serviços ambientais (Pearce \& Turner, 1989). 
Além da área ambiental "propriamente dita", aplicações importantes do método vêm sendo utilizadas na área de Saúde, incluindo segurança alimentar, como, por exemplo, no trabalho de Ravenswaay \& Wohl (1995), que estimaram a disposição a pagar por redução do risco de pesticidas em maçãs. A percepção do risco influi no valor atribuido: quanto maior o risco pressentido à saúde, maior a disposição a pagar (Sukharomana \& Supalla, 1998).

O método de valoração contingente consiste em perguntar diretamente à população afetada pelo projeto (usualmente, por meio de uma amostra representativa) os valores atribuídos a determinado serviço ambiental. Através de tratamento estatístico adequado, pode-se generalizar os dados, com margem de erro conhecida (Freeman, 1979; Mitchell \& Carson, 1989).

Um dos pressupostos básicos é que cada pessoa é capaz de expressar em termos monetários o valor total que atribui ao serviço de um dado recurso, e quanto maior o valor atribuído, maior se espera que seja sua disposição a pagar pela disponibilidade do serviço. Assim, os métodos baseados nas preferências declaradas procuram estabelecer "como as pessoas agiriam" em mercados hipotéticos (White \& Lovett, 1999). Há que se fazer, no entanto, uma ressalva: o valor total de um recurso ambiental poderá jamais ser estimado convenientemente, dado que um de seus componentes é o valor de existência. $O$ valor atribuído por populações não representadas na amostra (residentes fora da área de estudo, por exemplo) não é incorporado na análise. Indicações nesse sentido constam do trabalho de Pate \& Loomis (1997), que analisaram a influência da distância no valor atribuído, concluindo que, para alguns bens, há relação inversa entre distância e valor, mas o mesmo não se verifica para outros bens. Desta forma, delimitando-se a análise à população de uma dada região geográfica, é provável que se obtenha um valor total subestimado quando se extrapola a média para toda a população.

Como se trata de um cenário hipotético, especialmente construído visando estudar-se o problema detectado, para tornar legítima a aplicação da 
teoria de mercado é necessário que se garanta a similaridade da situação com mercados reais, exigindo que as pessoas consultadas tenham claras as informações necessárias para tomada de decisão (Hoevenagel \& Van der Linden, 1993; Belzer \& Theroux, 1995), diminuindo as fontes de erro da análise. $O$ valor da disposição a pagar é influenciado por informações, préexistentes e novas, de que a pessoa dispõe sobre o bem em avaliação, e de seus motivos, entre os quais crenças, valores atribuídos (de uso e de não-uso), relevância e ganhos e perdas vislumbrados (Harris \& Brown, 1992).

Nos EUA, resultados obtidos por avaliação contingente vêm sendo aceitos, há cerca de duas décadas, como medida monetária do impacto social de alterações ambientais. O Comprehensive Environmental Response, Conservation and Liability Act, de 1980, admite oficialmente a aceitação de resultados obtidos por avaliação contingente para estimativa do valor de danos ambientais e cálculo de eventuais pagamentos compensatórios (Ahlheim, 1998). O método é também aceito pela Corte de Apelação desde 1989, principalmente para o estabelecimento de valores de reparação em litígios decorrentes de danos ambientais, através da agregação das preferências individuais ou da ponderação das preferências de grupos com interesses conflitantes (Cooper \& Loomis, 1992; González-Cabán \& Loomis, 1997), podendo assumir o status de júri (Brown et al., 1995).

Em resenha de livro de Bishop \& Romano (1998), o comentarista enfatiza que diferenças culturais entre os EUA e a Europa (particularmente a Itália) fazem com que os métodos de valoração contingente sejam encarados de maneiras diferentes, havendo barreiras à aplicação mais ampla dos métodos nos países europeus, pela indiferença com que os agentes envolvidos (público, políticos e provedores de fundos) têm encarado os métodos, em que pese o conhecimento das técnicas por pesquisadores da área. No Brasil, não se tem notícia de aplicações semelhantes na formulação de políticas. $O$ que se 
conseguiu recuperar foram uns poucos trabalhos de natureza acadêmica, como os de Belluzzo Jr. (1995), Grasso et al. (1995) e Ribeiro (1998).

A análise feita por uma equipe de especialistas de renome internacional sobre os danos ambientais resultantes do vazamento de petróleo do cargueiro Exxon Valdez, na costa do Alasca, em 1989, resultou no documento que ficou conhecido como Relatório do Painel NOAA (National Oceanic and Atmospheric Administration), órgão do Departamento de Comércio norte-americano (Randall, 1997). Aquela agência estabeleceu algumas diretrizes para que resultados obtidos por avaliação contingente sejam aceitos como estimativa de prejuizos ou pagamentos compensatórios em casos de danos ambientais. As principais são: (i) no levantamento dos dados, as entrevistas devem ser pessoais; (ii) a amostra deve ser aleatória e com número mínimo de "não-respostas"; (iii) o levantamento só deve ser realizado após minucioso pré-teste; (iv) o problema e o método devem ser minuciosamente descritos; ( $v$ ) a especificação do método deve estar voltada para um desenho conservador; (vi) as "não-respostas" devem ser incluídas na análise para se aferir o resultado final, e (vii) deve haver acompanhamento posterior (follow up) detalhado. Além disso, estabelece que: (i) o formato deve ser de referendo, e não com perguntas em aberto, incluindo, além de "sim" e "não", a opção "não sei"; (ii) a resposta do entrevistado deve ser confidencial como em cabine de votação; (iii) ao entrevistado, devem ser lembradas a restrição orçamentária e a existência de substitutos.

As questões propostas aos participantes da pesquisa podem ser do tipo fechadas ou em aberto ${ }^{14}$, especialmente em relação ao preço $\$ p$. Nos trabalhos de Adamowicz et al. (1993) e de Brown (1994), por exemplo, pesquisas com questões em aberto resultaram em menores valores da disposição a pagar, o que seria desejável sob uma perspectiva conservadora

\footnotetext{
${ }^{14}$ Questões em aberto significa que a pessoa que participa da pesquisa declara o valor que atribui ao bem em análise sem a referência de valores propostos pelo pesquisador.
} 
dos valores obtidos para análise dos benefícios do projeto. Em doze comparações feitas por Brown et al. (1996), com base em trabalhos publicados por outros autores, os valores encontrados com questões fechadas foram sempre maiores que os obtidos com questões em aberto, sendo que em sete deles a relação ficou entre um e dois e, nos demais, acima disso. Entretanto, questões fechadas permitiram uma melhor definição do mercado contingente e resultaram em medidas estatisticas mais robustas. Questões em aberto podem dar margem a distorções provocadas por atitudes ideológicas ou de militância, de tratamento estatístico extremamente complexo (Bohara et al., 1998). Além disso, Cameron \& James (1987) consideram que questões em aberto são menos verossímeis para o consumidor, por serem raramente encontráveis em situações de mercado.

O formato do questionário para se inquirir o montante da disposição a pagar tem três variantes principais, de acordo com Mitchell \& Carson (1989), Boyle \& Bishop (1988) e outros: lances iterativos ("jogos de leilão", ou bidding games, em inglês), cartela de pagamento e opção dicotômica, isto é, com resposta "sim" ou "não" (Cameron \& James, 1987; Adamowicz et al., 1993; Brown, 1994). Em todas, a etapa inicial consiste em assegurar-se de que a pessoa que responde às perguntas dispõe de informação adequada para manifestar suas preferências no âmbito do cenário concebido pela pesquisa.

As informações mais relevantes referem-se a descrição do bem, nivel e estrutura da oferta, veículos e formas de pagamento, qual a base a ser onerada, agentes envolvidos e destino dos recursos. A quantidade de informação pode não ser constante dentro da amostra, se o objetivo é testar o poder explanatório dessa variável (Mitchell \& Carson, 1989). Resumidamente, as principais características de cada técnica são as seguintes: 


\section{a) lances iterativos}

O procedimento consiste em propor ao entrevistado um preço inicial $\$ \rho^{0}$, variável ao longo da amostra, a ser "desembolsado" (no mercado hipotético). Em caso de resposta afirmativa, isto é, se o participante concorda com o pagamento de $\$ p^{0}$, este valor é gradativamente aumentado, em faixas preestabelecidas, até se obter resposta negativa. $O$ preço mais alto com que 0 indivíduo concorda é tomado como sua máxima disposição a pagar pelo serviço ambiental em análise. Na alternativa oposta, isto é, se a pessoa não concorda com o preço inicial $\$ p^{0}$, este é sucessivamente reduzido, em faixas preestabelecidas, até se obter um preço que a pessoa se dispõe a pagar, que pode ser zero. A principal crítica que se faz a esta técnica é o risco de viés introduzido pelo valor inicial.

\section{b) cartela de pagamento}

Este é um instrumento em que estão impressos valores crescentes, de zero até um preço $\$ p$. O procedimento consiste em explicar ao participante da pesquisa a finalidade e o funcionamento da cartela e solicitar-Ihe que indique o preço que julga adequado, que é o valor final a considerar, tomado como a disposição a pagar do indivíduo. Os valores máximo e intermediários podem ser variáveis ao longo da amostra, como adotado por Boyle \& Bishop (1988), que utilizaram o critério de associar o valor de $\$ p$ à faixa de renda do participante. A adoção da cartela de pagamento visa reduzir a distorção causada pelo preço inicial dos lances iterativos, mas não evita o problema embutido na escala de valores monetários adotada. 
48.

\section{c) opção dicotômica}

A técnica conhecida por esta denominação, do tipo "pegue-ou-deixe", comporta apenas as respostas "sim" ou "não" a um dado preço proposto (Boyle \& Bishop, 1988; Blamey, 1998). A vantagem deste procedimento é a simplicidade de sua aplicação e a baixa exigência de esforço do respondente, necessitando, em contrapartida, de aparato estatístico mais sofisticado para tratar de valores discretos (Mitchell \& Carson, 1989). Numa pesquisa com 502 participantes de alpinismo em canyons, Boyle \& Bishop (1988) não encontraram diferenças significativas nos preços obtidos por lances iterativos e por cartela de pagamento, mas o preço estimado por opção dicotômica foi significativamente mais baixo.

Sob certas circunstâncias, o resultado pode ser considerado um referendo da população ao projeto em análise. Por exemplo, se o preço $\$ p^{0}$ for mantido constante para toda a amostra ou se forem apresentados aos participantes da pesquisa níveis alternativos de suprimento de qualidade ambiental $\left(q^{0}<q^{1}<\ldots<q^{1}\right)$ associados a taxas crescentes a serem pagas pela população. O produto de uma pesquisa dessa natureza é o número de pessoas, ou a fração da população, que aprova pagar $\$ p$ pelo nível $q$ de suprimento do serviço ambiental. Os principais problemas são a dificuldade de generalização dos resultados além da jurisdição do estudo e o viés potencial representado pelo preço inicial proposto, se a metodologia prevê ajustes sucessivos (Freeman, 1979). A alternativa é delinear a pesquisa com diferentes preços a serem submetidos à opção dicotômica (Randall, 1987).

Uma derivação importante da opção dicotômica é a que consiste em, na mesma entrevista, propor um preço alternativo condicionado à resposta dada pela pessoa à proposta inicial. A denominação usual para esta técnica é opção dicotômica com limite duplo. Exemplos de tratamento do assunto são 
encontrados em Hanemann et al. (1991), Kanninen (1993), Alberini et al. (1997), Harpman \& Welsh (1999) e Boland et al. (1999).

O procedimento é o seguinte: (a) se a resposta ao preço inicial $\$ p^{0}$ é "sim", propõe-se ao entrevistado um preço mais alto, $p^{a}>p^{0}$, obviamente com possibilidade de resposta "sim" ou "não", ou (b) se a resposta inicial é negativa, propõe-se um preço $p^{b}<p^{0}$, na expectativa de resposta positiva ou negativa. $O$ preço inicial é variável dentro da amostra, escolhido aleatoriamente de um conjunto preestabelecido de valores, e a cada valor de $p^{0}$ associam-se previamente os valores de $p^{a}$ e $p^{b}$ correspondentes. Uma adaptação a este procedimento foi utilizada por González-Cabán \& Loomis (1997): no caso de resposta duplamente negativa, propôs-se ao respondente um preço de US\$ 1,00 ao ano, considerado "muito pequeno" pelos autores. A análise tratou da disposição a pagar, durante cinco anos, para evitar danos ambientais de projetos de captação de água em Porto Rico.

O método de opção dicotômica com limite duplo é estatisticamente mais eficiente que o de limite simples, se a comparação leva em conta que os preços iniciais, no primeiro caso, são coincidentes com os preços utilizados no segundo caso (Hanemann et al., 1991). A essa vantagem, acrescente-se a de se exigirem amostras menores para dado nível de confiança estatística (Alberini, 1995).

\subsection{Discussão dos métodos de valoração contingente}

A estimativa de benefícios e custos sociais de projetos que envolvem alteração no suprimento de serviços ambientais, ao lado de sua larga utilização em alguns países, é motivo de críticas, principalmente em relação à precisão dos dados obtidos ${ }^{15}$. A iminência de tais imprecisões pode ter inibido o trabalho

\footnotetext{
${ }^{15}$ Abordagens detalhadas dos problemas potenciais do método de valoração contingente são encontradas em Cummings et al. (1986) e em Mitchell \& Carson (1989).
} 
50.

de muitos pesquisadores e provocado indiferença dos tomadores de decisões políticas (Batie \& Shabman, 1979). A possibilidade de distorções nos resultados levou Schulze (1994) a propor que os resultados obtidos sejam considerados válidos para o presente, dada a incerteza quanto aos gostos e preferências das "gerações futuras". No entanto, esta incerteza também ocorre em relação a bens de mercado, inclusive no curto prazo.

A valoração contingente envolve procedimentos tipicamente interdisciplinares (Blamey, 1998) e o desenvolvimento e a consolidação do método (ou métodos) só foram possiveis graças a contribuições da teoria do incentivo e de outras áreas da Psicologia e de avanços nas técnicas de levantamento e de modelagem econométrica (Randall, 1993). Não surpreende, portanto, que o tema dê margem a polêmicas que vão a extremos. Se há autores que elegem o método como único capaz de inferir o valor total de um serviço ambiental (Mitchell \& Carson, 1989), por outro lado há quem questione o próprio método, como Attfield (1998), que argumenta serem incompatíveis os conceitos de utilidade (derivada do consumo de bens) e de valor de existência, sendo este, por definição, atribuido por indivíduos que não consomem o recurso nem vislumbram a oportunidade de fazê-lo no futuro. Entre esses extremos, aparecem posições como a de Söderbaum (1994), para quem a visão de que os indivíduos e as empresas reagem como máquinas aos preços de bens e serviços não é totalmente satisfatória, sendo apenas uma das alternativas possiveis, ou parte da explicação do comportamento do consumidor, cuja decisão de consumo não depende apenas de suas preferências, mas também de suas crenças (Akerlof \& Dickens, 1982). Neste cenário, ao consumidor da teoria neoclássica dever-se-ia acrescentar seu papel como cidadão (Sagoff, 1998), que manifesta em sua disposição a pagar um sinal de sua quota de responsabilidade social e não apenas uma medida de seus ganhos ou perdas de bem-estar individual, obtendo satisfação por seu comportamento altruístico (Ajzen et al., 1996; More et al., 1996). Filosofias à 
parte, de maneira pragmática, é razoável esperar-se que o método permita a estimativa de valores aproximados da disposição a pagar, dentro de certos intervalos, tão mais precisos quanto mais cuidadosos forem os procedimentos adotados.

No método de valoração contingente, as preferências são construídas durante o processo. Se a descrição do cenário contiver muitos argumentos em favor da meta politicamente desejada ("comunicação persuasiva"), ou se o receptor da mensagem não estiver suficientemente motivado e apto a processar os argumentos, há a tendência a um julgamento superficial, e pode haver distorção do valor da disposição a pagar (Ajzen et al., 1996). Esse problema pode surgir também em situações em que a aplicação do questionário torne-a maçante (muito longa, em lugar desconfortável) ou, conforme alerta Randall (1986), pode soar ofensiva ao entrevistado se sua verdadeira disposição a pagar estiver muito distante, acima ou abaixo, do preço proposto. Este é um problema de extrema complexidade, pois, por pressuposição, a verdadeira disposição a pagar por um determinado bem ou serviço só é conhecida pelo próprio indivíduo.

As principais controvérsias sobre o método de valoração contingente dizem respeito ao risco de distorção dos resultados e podem ser divididas em algumas categorias principais ${ }^{16}$ : comportamento estratégico da pessoa que responde ao questionário, concepção do mercado contingente e formato e condução do levantamento dos dados. A itemização desses assuntos tem um caráter essencialmente didático, dado que muitos dos problemas comentados a seguir, especialmente os ligados a comportamento humano, permeiam mais de um tipo de risco de distorção analisado. O êxito do trabalho depende, em parte, do formato da pesquisa, que varia com a natureza do bem em análise, com

\footnotetext{
${ }^{16}$ Ver, a respeito, encontro de especialistas relatado por Cummings et al. (1986).
} 
restrições metodológicas e teóricas, com a população envolvida e com a habilidade do pesquisador (Mitchell \& Carson, 1989).

\subsubsection{Comportamento estratégico}

Uma das críticas mais recorrentes aos métodos de valoração contingente diz respeito à possibilidade de comportamento estratégico de quem responde ao questionário. Se a pessoa se convence de que não precisa pagar efetivamente o preço proposto, e que este valor influi no nível de suprimento de um serviço ambiental pelo qual tem interesse, tende a superestimar o valor que Ihe atribui, isto é, declara uma disposição a pagar superior ao valor que realmente imputa ao recurso em análise. Por outro lado, se acredita que sua resposta influirá em níveis de taxação, tende a subavaliar a qualidade ambiental. Na ausência de ameaças, a pessoa tende a expressar sua disposição a pagar mínima, e não média (Samuelson, 1954; Freeman, 1979; Bishop \& Heberlein, 1979; Schulze et al., 1981; Randall, 1987; Mitchell \& Carson, 1989).

A detecção do viés estratégico é extremamente complexa, exigindo procedimentos como subdivisão da amostra e elaboração de questionários com e sem incentivos ao comportamento. $O$ procedimento mais aceito nos trabalhos consultados que tratam do assunto é, de forma genérica, construir o modelo cuidadosamente, de maneira a evitar tanto quanto possível incentivos a sub ou sobrevalorização do serviço ambiental, reconhecer o risco do problema e deixar isto claro aos leitores (Belluzzo Jr., 1995). No entanto, conclusão de Cummings et al. (1986), baseada na análise de uma série de trabalhos publicados, incute um pouco de tranqüilidade sobre a validade da pesquisa aqui proposta. Textualmente: 
53.

"Thus, while acknowledging the absence of a basis for categorical conclusions in this regard, we suggest that a minimum, a basis does exist for diminishing the 'prionity' position in research agendas that the strategic bias hypothesis has enjoyed for the past decade" (p.26, itálicos adicionados).

Quando se identifica, numa declaração de disposição a pagar nula, a manifestação de atitudes políticas ou de protesto, alguns autores recomendam retirar da amostra tais observações, por serem consideradas aéticas (Freeman, 1986; Mitchell \& Carson, 1989; Belluzzo Jr., 1995), embora Randall (1986) considere que, na forma agregada, os benefícios estimados por valoração contingente não são expressivamente "influenciados por relativamente poucas observações excêntricas". Uma questão que aqui se levanta, sem se procurar a resposta, é: por que excluir da análise observações que refletem manifestações de parte da população afetada pelo projeto? Não obstante, no capitulo 4 apresentar-se-ão as estimativas nas duas situações, sem e com a exclusão das manifestações de protesto.

\subsubsection{Concepção do mercado contingente}

Um outro conjunto de críticas ao método de valoração contingente pode ser englobado sob o título acima. Referem-se ao risco de introdução de distorções na análise, isto é, na estimativa do valor verdadeiro da disposição a pagar, decorrentes dos valores propostos, da experiência anterior e do nivel de informação da pessoa que responde ao questionário, do veículo proposto para se concretizar a disposição a pagar (incluindo agentes executores e destino dos recursos), do tempo disponivel para decidir sobre a transação e da recorrência à restrição orçamentária. 


\section{a) Preço inicial}

Quando a metodologia de levantamento dos dados prevê ajustes sucessivos para cima ou para baixo, dependendo da primeira resposta (lances iterativos), o preço inicial pode influenciar o valor final a ser obtido (Freeman, 1979; Boyle \& Bishop, 1988; Mitchell \& Carson, 1989; Pearce \& Turner, 1989), até porque, se o preço proposto estiver muito distante do verdadeiro valor de sua disposição a pagar, a pessoa pode sentir-se irritada ou considerar o processo maçante (Randall, 1986). Entretanto, em revisão de trabalhos publicados, Boyle et al. (1985) não encontraram indicação efetiva de que realmente exista o viés mencionado.

\section{b) Experiência anterior $\mathbf{e}$ informação}

Em mercados reais, o comportamento observado das pessoas é uma resposta ex-post a estímulos, passivel de reavaliação com base na experiência adquirida. Em mercados hipotéticos, a resposta dada resulta de uma avaliação ex-ante das informações disponiveis (Schulze et al., 1981). As pessoas podem avaliar com pouca precisão os valores atribuídos a um serviço ambiental. Esse valor é construído durante o processo e pode variar de acordo com o contexto em que se dá a resposta (Gregory et al., 1995; Gregory \& Slovic, 1997) ${ }^{17}$, com o propósito do projeto (Mularkey \& Bishop, 1999) e com aspectos de natureza social, de motivação e de capacidade cognitiva dos participantes (Mitchell \& Carson, 1989).

\footnotetext{
${ }^{17}$ Carson et al. (1997), testando a validade temporal do método, não encontraram diferenças significativas com os valores originalmente obtidos da disposição a pagar, no caso do vazamento de petróleo do cargueiro Exxon Valdez.
} 
Bens não negociados em mercado não constam da experiência acumulada pela pessoa em suas transações como consumidor (Freeman, 1979). Isto pode fazer com que seja levada a tomar a decisão sem dispor dos mecanismos necessários à opção pela melhor alternativa. Em função de insuficiente conhecimento anterior, as pessoas podem responder com pouca reflexão sobre o assunto (Gregory \& Slovic, 1997; Loomis \& Ekstrand, 1998). Note-se que este mesmo problema pode ocorrer com produtos novos, ou com produtos triviais que são adquiridos pela primeira vez. Neste caso, entretanto, usualmente há oportunidades subseqüentes de ajustes na direção do comportamento adequado, o que não ocorre em análises de valoração contingente baseadas em dados obtidos de uma única vez. Para Randall (1986), no entanto, as penalidades para quem toma a decisão "errada" diferem apenas em grau quando se comparam mercados reais e contingentes, se é que, segundo o autor, há alguma diferença.

O argumento de Freeman (1986) é que, para quaisquer tipos de bens, uma perturbação na linha orçamentária faz com que a pessoa leve algum tempo para se ajustar à nova situação. No caso específico de serviços ambientais, exceto para os totalmente inéditos para a pessoa, o erro de avaliação será tanto maior quanto mais larga for a diferença entre o nível atual de suprimento (ao qual a pessoa já se adaptou) e o nivel proposto. Se o erro não for sistemático, isto é, se for aleatório, admitindo-se que tem média zero, isto faz com que se anule ao longo da amostra, se esta for "suficientemente grande". Das colocações do autor, conclui-se que a falta de experiência anterior não é um problema metodológico sério, podendo ser reduzido com o suprimento de informação suficiente ao indivíduo participante da pesquisa.

A evidência de que uma maior carga de informação implica em maior disposição a pagar foi observada por Bergstrom et al. (1990a). Por outro lado, Blomquist \& Whitehead (1998) alertam para o fato de que as informações prestadas durante o processo de levantamento podem reduzir a disposição a 
pagar, dependendo da crença inicial da pessoa sobre o valor dos serviços ambientais em análise.

O conhecimento prévio dos custos do projeto e dos valores atribuídos por outras pessoas pode introduzir viés na análise, recomendando-se que não se dê ao respondente esse tipo de informação (Freeman, 1986). Quanto ao serviço ambiental e ao mercado contingente, diferentes niveis de informação podem levar a diferentes valores atribuídos. Neste projeto, o critério adotado é fornecer a mesma carga de informação a todos os participantes da pesquisa, restando por resolver a diferença de conhecimento pré-existente.

\section{c) Tempo para tomada de decisão}

Em situações de mercado, não é raro o indivíduo despender um tempo mais ou menos longo estudando alternativas, consultando pessoas ou fazendo cálculos, em busca da "melhor" decisão. Alguns métodos de avaliação contingente não oferecem essa possibilidade (Bishop \& Heberlein, 1979), pelo próprio formato da pesquisa ou por limitação de prazos institucionais. Em transações de mercado, o fato de o consumidor tomar uma atitude intempestiva, isto é, realizar uma transação sem analisar detalhadamente todas as informações disponiveis e as vantagens e desvantagens de seu ato, implica em custos desnecessários ou em perda de utilidade. Em mercados hipotéticos, construídos para se estimar o valor monetário de um serviço ambiental, tal incentivo teoricamente não existe, até porque a maioria das técnicas de levantamento dos dados não deixa ao respondente tempo suficiente para análise adequada das informações disponiveis (Freeman, 1979; Pearce \& Turner, 1989), e esse fator pode influir no valor da disposição a pagar, segundo Whittington et al. (1992). Em pesquisa sobre disposição da população de região da Nigéria a pagar por água corrente, não disponivel até aquele momento, os autores concluíram que, se a pessoa tem tempo para refletir 
sobre o assunto, há uma tendência de redução da disposição a pagar, mas esta redução pode estar sendo mascarada por comportamento estratégico. Se as pessoas da comunidade sabem quem são os elementos da amostra, trocas de informações sobre valores declarados podem fazer com que os indivíduos proponham preços mais baixos, se tiverem uma segunda oportunidade de se manifestar.

\section{d) Veículo de pagamento}

Refere-se ao mecanismo proposto para as pessoas efetivarem sua disposição a pagar. Neste item, mais genericamente, abordam-se outros temas relacionados, como confiança das pessoas no "governo" (essa entidade tão citada e tão abstrata), no uso dos recursos e outros.

Não há consenso na literatura sobre diferenças significativas entre veículos de pagamento. No caso do Brasil, há uma percepção intuitiva de que as pessoas têm a sensação de que pagam muito em taxas e impostos e de que recursos geridos pelo "governo" têm sua aplicação desviada dos objetivos inicialmente utilizados como argumento para a taxação. Sem uma base referencial disponivel, e apenas à guisa de ilustração, citem-se dois casos recentes, fartamente veiculados nos meios de comunicação massal. O primeiro é a chamada Contribuição Provisória sobre Movimentações Financeiras (CPMF), instituída pelo governo federal sob a justificativa de arrecadar recursos para a saúde pública. Ao lado da crítica continuada de segmentos da sociedade sobre sua validade, principalmente dos empresários, os recursos dessa rubrica vêm sendo sistematicamente utilizados para cobrir outros itens de despesas. O segundo caso é a tentativa do governo estadual paulista, em 1999 , de instituir um pagamento adicional $(R \$ 2,50)$ às contas por uso de telefone, para reequipar o aparato de segurança pública do Estado. A reação social, a confiar nos meios de comunicação, foi frontalmente contrária à 
58.

proposta, levando o governo a desistir da idéia. Este é um caso típico em que o tomador de decisões políticas visualizou a possibilidade de extrair da população seu excedente compensatório pelo acréscimo no suprimento de um bem público (segurança), mas não usou instrumentos adequados para estimar o valor verdadeiro - ou, pelo menos, o valor mínimo - da disposição a pagar.

O valor atribuído a um serviço ambiental pode ser influenciado pelo entendimento que a pessoa tem da responsabilidade do governo e suas agências no processo, que podem estar envolvidos nas causas ou na condução do problema, o que pode acarretar sentimento de desconfiança da utilização dos recursos ou de que "o povo está sendo explorado" (Blamey, 1998). Isto pode fazer com que a pessoa tente defender-se de pagar algo pela tendência racional de subestimar os valores, por desconfiança na eficácia no emprego dos recursos arrecadados, por impotência ou por atribuir a responsabilidade a terceiros (Randall, 1987). Além disso, a origem proposta dos recursos pode influenciar a avaliação (Posavac, 1998).

A forma visualizada para se captar qualitativamente esses comportamentos é incluir questões que permitam ao respondente expressar suas convicções sobre a responsabilidade pelo suprimento do serviço ambiental ("governo", outros segmentos da sociedade) e sobre sua confiança no uso dos recursos.

\section{e) Restrição orçamentária}

A possibilidade de distorção do valor da disposição a pagar por se neglicenciar a restrição orçamentária, conforme alerta do "Painel NOAA", foi testada por Loomis et al. (1994), confrontando dados de duas subamostras. Apenas numa delas, os participantes foram alertados sobre a restrição orçamentária e existência de substitutos. Os autores não encontraram diferenças significativas entre os dois tratamentos. 
Testando a diferença de percepção entre pagamentos de uma só vez e a intervalos regulares, Stevens et al. (1997) concluíram que as pessoas conseguem diferenciar as duas modalidades, mas a taxa de desconto inferida mostrou-se excepcionalmente alta.

Para Randall (1986), o problema da restrição orçamentária influi principalmente na disparidade entre disposição a pagar e disposição a aceitar compensação. Se a pessoa é incapaz de resolver adequadamente a maximização subjacente, então há uma subestimativa da disposição a pagar e superestimativa da disposição a aceitar compensação. Este assunto, porém, já foi, espera-se, satisfatoriamente discutido em seção anterior deste trabalho.

\subsubsection{Considerações adicionais}

O ambiente é tipicamente multidimensional, caracterizando-se por tradeoffs entre diferentes serviços e diferentes grupos de usuários. Isso pode resultar em preços diferentes se analisados componente a componente ou o conjunto dos serviços ambientais. Isso, no entanto, pode ocorrer também com bens de mercado. Apresentada à pessoa uma seqüência de bens ambientais, a disposição a pagar declina à medida que determinado recurso é mencionado mais afastado do início da série (Hoehn \& Randall, 1989; Hoehn, 1991; Randall \& Hoehn, 1996). No entanto, considera-se o método adequado para a análise do valor total de pequeno número de atributos, o que usualmente ocorre com agências locais de gestão ambiental (Dupont, 1997). A não percepção da complexidade ambiental resulta em perda de informação, dados os níveis de conhecimento das pessoas, da incongruência de alguns procedimentos (bens não passiveis ou de difícil valoração) e da própria composição dos serviços ambientais. O caráter multidimensional do ambiente, com seus valores ecológico, científico, recreativo, estético, de suporte à vida, religioso e econômico, faz com que o indivíduo tenda a adotar estratégias simplificadoras, 
60.

requerendo ajuda para articular os valores e combiná-los (Vatn \& Bromley, 1995; Gregory \& Slovic, 1997). Além disso, pode haver uma tendência de as pessoas concordarem com o entrevistador (yea-saying), se esta sua atitude não implicar em custos (Mitchell \& Carson, 1989; Blamey et al., 1999). Dadas essas dificuldades, Vatn \& Bromley (1995) consideram mais importante a detecção de mudanças no status quo do que o nível absoluto de disponibilidade do recurso.

\subsection{Técnicas de levantamento}

O uso crescente do levantamento de dados de natureza sócioeconômica através de questionário (survey) baseia-se no desenvolvimento de técnicas de amostragem probabilística e da própria construção do questionário. Os veículos comumente utilizados, isoladamente ou combinados, são correio, entrevista por telefone e entrevista face a face (Mitchell \& Carson, 1989) e discussão em grupos de interesse. Usualmente, as questões envolvem a construção de cenários complexos, que requerem explicação detalhada ao respondente, o que pode ser facilitado com o emprego de auxílios visuais e com a seqüência e ritmo possiveis em entrevistas. $O$ total de recursos e o tempo disponiveis para se realizar a pesquisa acabam tendo influência na escolha da técnica. Os resultados de pesquisas caras e demoradas podem, muitas vezes, ser aproximados satisfatoriamente por alternativas mais rápidas e menos dispendiosas, ressalvadas as margens de erro correspondentes (Harrison \& Lesley, 1996).

Se os respondentes têm pequena ou nenhuma experiência anterior com o bem em análise, Ajzen et al. (1996) lembram o risco de problemas potenciais na qualidade dos dados, exigindo descrição clara do recurso e da transação subjacente. Além disso, a natureza e a qualidade dos argumentos apresentados influem na intensidade da mudança de atitude das pessoas, 
sujeita a sua capacidade de entendimento, motivação, relevância atribuída ao serviço ambiental e disposição pessoal (altruísmo, individualismo), além do risco percebido, que pode influenciar na decisão (Kahneman \& Tversky, 1979; More et al., 1996).

Além do valor da disposição a pagar, é recomendável que levantamentos dessa natureza contenham informações e quesitos que permitam identificar características dos participantes (Randall, 1987; Mitchell \& Carson, 1989) como, por exemplo, sexo, idade, nível educacional, nível de renda e outros (Loomis \& González-Cabán, 1998). Para diminuir desconfianças em relação à declaração de dados pessoais "sensiveis" (renda, principalmente), recomenda-se que as respostas sejam confidenciais e anônimas (Ajzen et al., 1996).

A coleta de dados por telefone é um processo de custo relativamente mais baixo que o de outras técnicas. Permite a interação entrevistadorentrevistado, mas não pode contar com auxílios visuais na descrição do problema. Tem o inconveniente de excluir a parte da população que dispõe de telefones não listados ou que não tem telefone (Mitchell \& Carson, 1989; Whitehead et al., 1998; White \& Lovett, 1999). Este segundo aspecto é particularmente importante no Brasil, em que parte significativa da população não tem acesso a telefone particular. Pesquisa de Pate \& Loomis (1997) utilizou a lista de assinantes de linhas telefônicas para sorteio da amostra, para obtenção dos respectivos endereços, aos quais foram remetidos questionários por via postal, e para agendar as entrevistas, realizadas nos endereços dos participantes. Neste caso, a garantia de sigilo depende de o participante acreditar que será mantido.

A remessa e retorno do questionário pelo correio tem as vantagens de se poder utilizar auxílios visuais na descrição do recurso ambiental e de se dar tempo ao respondente para refletir sobre a transação proposta. As principais desvantagens são o tempo de espera e a baixa expectativa de retorno de 
questionários preenchidos, além do risco de preenchimento incompleto. Analisando 16 trabalhos publicados, Mitchell \& Carson (1989) verificaram em apenas dois casos taxas de resposta superiores a $70 \%$. No somatório de todas as pesquisas, num total de 21.886 questionários remetidos, apenas $40 \%$ retornaram preenchidos. A acuidade das respostas está condicionada ao entendimento que o respondente tem do material (texto, auxílios visuais, perguntas do questionário), o que é, no mínimo, temerário frente ao grau de instrução e de habilidade de leitura de grande parte da população brasileira. Além disso, há o risco latente, dificilmente comprovável, de que as respostas sejam viesadas pelo interesse de determinadas pessoas no projeto que, em princípio, estariam mais motivadas a atender a pesquisa (Mitchell \& Carson, 1989, p.277).

A técnica que pode aliar o uso de auxílios visuais e interação com a pessoa é a entrevista face a face, que Mitchell \& Carson (1989) consideram apropriada para induzir a cooperação do respondente, além de ser, para as condições norte-americanas, a única recomendada pelo "Painel NOAA". Permite repetir explicações no caso de dúvidas e criar um clima de "cumplicidade" entre entrevistador e entrevistado. Uma das variantes dessa técnica é a entrevista no endereço da pessoa incluída na amostra. Este procedimento tem a vantagem de permitir delinear amostras que representem o perfil da população estudada, se cadastros adequados estiverem disponiveis. Há, porém, o risco de "não-respostas", se as pessoas não se encontram no endereço, se estão "muito ocupadas" ou por outras razões. A pesquisa pode acabar se tornando mais onerosa se houver necessidade de o entrevistador repetir a tentativa uma ou mais vezes. Para o aspecto de sigilo das informações, vale o que foi anotado para as entrevistas por telefone.

Uma das alternativas da entrevista face a face é a abordagem em pontos de fluxo de pessoas. Spooner \& Flaherty (1993) e Miller et al. (1997) utilizaram essa técnica e a compararam com outras, na mesma pesquisa. 
Concluiram que a abordagem-na-rua (street intercept) é uma técnica mais barata e superior em qualidade à pesquisa por telefone (em ambos os casos) e à discussão em grupos-focos (no primeiro caso). Para estimar a disposição a pagar por redução da poluição em rio de Goiânia (estado de Goiás, Brasil), Ribeiro (1998) utilizou essa técnica de levantamento, no que a autora chamou de "amostra intencional", isto é, representada por pessoas que estavam comprando ou portavam hortaliças, em feiras da cidade.

A técnica de abordagem na rua, se as questões são adequadamente elaboradas, garante ao entrevistado que suas informações são sigilosas e anônimas. Para isto, não se incluem questões de identificação (nome, endereço, telefone) do entrevistado. Esta é a técnica proposta neste trabalho.

Do ponto de vista estatístico, há o risco de a amostra não representar adequadamente o perfil sócio-econômico da população (faixas de idade, de escolaridade, de renda), o que só se verifica a posteriori. O risco de introdução de erro sistemático é mínimo se os locais são escolhidos aleatoriamente e se a abordagem das pessoas seguir critérios de casualidade previamente estabelecidos. Miller et al. (1997), em pesquisa sobre jovens consumidores de drogas, dividiram a área de estudo em blocos (quarteirões), que receberam numeração crescente e foram sorteados por um programa de computador gerador de números aleatórios.

A seqüência recomendada para a entrevista é, primeiro, fornecer ao entrevistado informação adequada do serviço ambiental em avaliação, do mercado contingente e da forma de transação proposta. Quando é o caso, incluem-se informações sobre aspectos ambientais, legais e econômicos envolvidos no problema. Em seguida, havendo a percepção de que a pessoa entendeu o cenário descrito, constam as perguntas destinadas a extrair o valor da disposição a pagar e, por último, a anotação das características sócioeconômicas do entrevistado (Randall, 1987; Mitchell \& Carson, 1989). 
Em muitos trabalhos sobre valoração contingente, na construção do questionário, adota-se um número relativamente grande de preços iniciais, o que pode dar mais informação sobre a variabilidade da disposição a pagar e pode ser mais forte estatisticamente quando as probabilidades de resposta têm distribuição assimétrica. No caso de opção dicotômica com limite duplo, no entanto, a conclusão de Alberini (1995) é que se pode utilizar um vetor com quatro a seis valores iniciais, com muito pequenos ganhos de eficiência quando se utilizam mais valores.

Pelo exposto neste capitulo, se a intenção é obter uma estimativa conservadora (preços mais baixos) do impacto no bem-estar provocado por uma alteração no suprimento de um serviço ambiental, os principais pontos a considerar são:

(i) a pesquisa deve ser modelada dando-se preferência à disposição a pagar, em detrimento da disposição a aceitar compensação;

(ii) para estimar-se o valor total (uso e não-uso) atribuído pelo indivíduo, a melhor alternativa é através de valoração contingente;

(iii) a pessoa que responde ao questionário deve receber informação suficiente para declarar suas preferências;

(iv) as respostas devem ser confidenciais e anônimas;

(v) questões em aberto resultam em valores mais baixos da disposição a pagar do que questões fechadas, mas têm maiores problemas estatísticos e assemelham-se menos a situações reais de mercado;

(vi) no caso de questões fechadas, o modelo de opção dicotômica com limite duplo é estatisticamente mais eficiente que o de limite simples;

(vii) o ideal é que o respondente tenha tempo suficiente para deliberar sobre sua disposição a pagar.

Neste trabalho, propõe-se seguir o que está recomendado acima, exceto os itens (v) e (vii). Esta pesquisa opta por questões fechadas para evitar os problemas apontados por Bohara et al. (1998). Para obedecer o item (vii), 
65.

seria necessário um tipo de levantamento que permitisse retornar ao entrevistado algum tempo após o primeiro contato (Whittington et al., 1992), o que não será possível com o tipo de levantamento que aqui está se propondo, de realizarem-se as entrevistas em pontos de fluxo de pessoas (abordagem na rua).

Em resumo, esta pesquisa levanta dados através de entrevistas na rua, com questões fechadas, aplicadas a uma amostra da população da área de estudo (municípios que englobam a bacia do rio Corumbataí), em pontos de fluxo de público escolhidos aleatoriamente. Os dados obtidos destinam-se a estimar a disposição média a pagar pela reposição de matas ciliares na bacia hidrográfica mencionada e a associar esse valor a características sócioeconômicas da população. O valor apurado para toda a população a partir do valor médio será provavelmente subestimado, dado que não se está captando o valor atribuído por segmentos populacionais não representados na amostra. 


\section{MODELO PROPOSTO}

Pelo exposto no capítulo anterior, conclui-se que a disposição a pagar é a medida mais adequada para se estimar o impacto no bem-estar decorrente de uma acréscimo no suprimento dos serviços de um recurso ambiental. 0 objetivo central de pesquisa nessa área é estimar-se um valor monetário do impacto, correspondente ao preço médio aceito e depois generalizado para toda a população afetada pelo projeto. Para tanto, é necessário dispor-se de procedimentos econométricos adequados.

\subsection{Modelos econométricos}

Há duas correntes principais dominando a literatura sobre o assunto. Por facilidade de referência, e seguindo-se o que fez Belluzzo Jr. (1995), serão chamadas de abordagem de Cameron e abordagem de Hanemann ${ }^{18}$. A segunda tem a preferência disparada dos autores que vêm publicando trabalhos de valoração contingente e, em sua formulação básica, será o fundamento do modelo adotado neste trabalho.

A abordagem de Cameron deriva a chamada função valoração. $O$ modelo foi proposto inicialmente por Cameron \& James (1987) e pressupõe

\footnotetext{
${ }^{18}$ Belluzzo $\mathrm{Jr}$. apresenta em seu trabalho formalização matemática e comparação detalhada entre os dois modeios.
} 
que o preço que a pessoa se dispõe a pagar é uma variável aleatória, não observável diretamente pelo pesquisador, expressa, para cada indivíduo $i$, por ${ }^{19}$

$$
p_{i}^{*} \equiv \omega_{i}^{\prime} \beta+\varepsilon_{i}
$$

onde $\rho^{*}$ é a disposição a pagar, $\omega$ é um vetor de características individuais, $\beta$ é um vetor de parâmetros e $\varepsilon$ é o erro, pressuposto uma variável aleatória independente e identicamente distribuída. A variável $\rho^{*}$ não é observável diretamente, mas através de índices colhidos por opção dicotômica, o que obriga a utilização de métodos de estimação com variáveis qualitativas.

A cada indivíduo da amostra propõe-se um valor arbitrário $p_{i}$, escolhido aleatoriamente. Pela resposta ("sim" ou "não"), infere-se se o verdadeiro valor $p_{i}^{*}$ é maior ou menor que o valor proposto. Simbologia: $d_{i}=1$ para resposta afirmativa e $d_{i}=0$ em caso contrário; prob: abreviatura e $\pi$ símbolo de probabilidade; $s$ e $n$ : sobrescritos para "sim" e "não", respectivamente. Pressupondo-se que $\varepsilon$ tem distribuição normal com média zero e desvio padrão $\sigma$, pode-se escrever:

$$
\begin{aligned}
& \pi_{i}^{s}=\operatorname{prob}\left\{d_{i}=1 \mid \omega_{i}\right\}=\operatorname{prob}\left\{p_{i}^{*}>p_{i}\right\} \\
& \pi_{i}^{s}=\operatorname{prob}\left\{\omega_{i}^{\prime} \beta+\varepsilon_{i}>p_{i}\right\} \\
& \pi_{i}^{s}=\operatorname{prob}\left\{\varepsilon_{i}>p_{i}-\omega_{i}^{\prime} \beta\right\} \\
& \pi_{i}^{s}=\operatorname{prob}\left\{z_{i}>\frac{1}{\sigma}\left(p_{i}-\omega_{i}^{\prime} \beta\right)\right\}
\end{aligned}
$$

onde $z$ é a variável aleatória normal padrão. Então, representando-se por $G$ a função de distribuição normal, resulta que

\footnotetext{
${ }^{19}$ Com o intuito de manter certa uniformidade neste trabalho, a notação original foi adaptada.
} 
68.

$$
\begin{aligned}
& \pi_{i}^{s}=1-G\left[\frac{1}{\sigma}\left(p_{i}-\omega_{i}^{\prime} \beta\right)\right] \mathrm{e} \\
& \pi_{i}^{n}=G\left[\frac{1}{\sigma}\left(p_{i}-\omega_{i}^{\prime} \beta\right)\right]
\end{aligned}
$$

Dada uma amostra de $m$ observações independentes, o logaritmo da função de verossimilhança $(L)$ é dado por:

$$
\ln L=\sum_{i=1}^{m}\left\{d_{i} \ln [1-G(.)]+\left(1-d_{i}\right) \ln G(.)\right\}
$$

com a expressão de $G($.$) , no caso da distribuição normal, sendo dada pelo lado$ direito da eq.( 21 ). Por maximização da verossimilhança, obtêm-se estimativas de $\beta$ e de $\sigma$. A abordagem de Cameron não leva em conta, em sua derivação, o conceito de utilidade.

A condição de primeira ordem para maximização de $\ln L$ (idêntico a maximizar $L$ ), de uma função de distribuição $G$ qualquer, resulta em

$$
\frac{\partial \ln L}{\partial \beta}=\sum_{i=1}^{m}\left[d_{i} \frac{-1}{1-G} \frac{\partial G}{\partial \beta}+\left(1-d_{i}\right) \frac{1}{G} \frac{\partial G}{\partial \beta}\right]=0
$$

Para diversas formulações de $G$, a solução da eq.( 23 ) depende da aplicação de métodos não lineares de estimação, como o de Newton-Raphson, por exemplo. O método citado utiliza procedimento iterativo, partindo-se de um vetor inicial arbitrário $\beta_{t=0}$ e fazendo-se sucessivamente

$$
\hat{\boldsymbol{\beta}}_{t+1}=\hat{\boldsymbol{\beta}}_{t}-\left[\left.\frac{\partial^{2} \ln L}{\partial \beta \partial \beta^{\prime}}\right|_{\hat{\boldsymbol{\beta}}_{t}}\right]^{-1}\left[\left.\frac{\partial \ln L}{\partial \beta}\right|_{\hat{\boldsymbol{\beta}}_{t}}\right]
$$

em que $\hat{\beta}_{t}$ é o resultado calculado na etapa $t$ do procedimento. Os valores obtidos pela aplicação sucessiva da eq.( 24 ) devem convergir para os valores 
69.

procurados de $\hat{\beta}$, de acordo com Maddala (1983), Judge et al. (1988) e Greene (1997).

A condição de segunda ordem para máximo é que seja definida negativa a matriz hessiana, ou matriz de informação:

$$
I(\beta)=\frac{\partial^{2} \ln L}{\partial \beta \partial \beta^{\prime}}
$$

As estimativas de $\beta$ assim obtidas são consistentes, assintoticamente eficientes e com distribuição normal assintótica (Judge et al., 1988). A matriz de covariâncias é dada por $-E[/(\beta)]^{-1}$.

O modelo proposto por Hanemann (1984), por outro lado, parte da função indireta de utilidade $u=v(\mathbf{p}, q, r)$, dada pela eq.( 12$)$. A formulação do autor, aqui com simbologia adaptada, é

$$
u(d, r \mid \omega)=v(d, r \mid \omega)+\varepsilon_{d}
$$

onde $d=1$ na presença do evento e $d=0$ em caso contrário; $r$. renda individual; $\omega$ : vetor de atributos e características individuais e $\varepsilon_{d}$ : erro aleatório.

O pressuposto básico do modelo é que o indivíduo é plenamente capaz de avaliar seus níveis de utilidade $u^{0}$ e $u^{1}$, níveis esses não observáveis pelo pesquisador. $O$ indivíduo dispõe-se a pagar o preço $p$ pela implementação do projeto se

$$
v(1, r-p \mid \omega)+\varepsilon_{1}>v(0, r \mid \omega)+\varepsilon_{0}
$$

Então, a probabilidade de uma resposta afirmativa $\pi^{s}=\operatorname{prob}\{d=1\}$ é

$$
\pi^{s}=\operatorname{prob}\left\{v(1, r-p \mid \omega)+\varepsilon_{1}>v(0, r \mid \omega)+\varepsilon_{0}\right\}
$$

e a probabilidade de uma resposta negativa, $\pi^{n}=\operatorname{prob}\{d=0\}$, é dada por

$$
\pi^{n}=1-\pi^{s}
$$


Se os erros $\varepsilon_{0}$ e $\varepsilon_{1}$ são independentes e identicamente distribuídos, $\varepsilon=\varepsilon_{1}-\varepsilon_{0}$ e $\bar{\varepsilon}=\varepsilon_{0}-\varepsilon_{1}$ têm a mesma distribuição. Então, a probabilidade de aceitação pode ser escrita como

$$
\pi^{s}=F_{\varepsilon}(\Delta v)
$$

onde

$$
\Delta v=v(1, r-p \mid \omega)-v(0, r \mid \omega)
$$

O ponto em que o indivíduo é indiferente entre pagar e não pagar, isto é, em que $\pi^{s}=\pi^{n}=0,5$, é determinado fazendo-se $\Delta v=0$.

O modelo de Hanemann (1984) exige a especificação da função utilidade, e o autor utilizou os modelos propostos por Bishop \& Heberlein (1979), $u=\alpha+\beta r$ e $u=\alpha+\beta \ln r$ (omitido o vetor $\omega$ ), com $\beta>0$. Considerandose o primeiro modelo, obtém-se:

$$
\Delta v=\alpha-\beta p
$$

(onde $\alpha=\alpha_{1}-\alpha_{0}$ ) e resulta em

$$
\pi^{s}=F_{\varepsilon}(\alpha-\beta p)
$$

Sendo $p^{\star}$ sua máxima disposição a pagar, a probabilidade de 0 individuo $i$ concordar com o pagamento de $p_{i}$ é

$$
\pi_{i}^{s}=\operatorname{prob}\left\{p_{i}^{*}>p_{i}\right\}=1-G_{i}(p)
$$

onde $G(p)$ é a função de distribuição de $p^{\star}$, tendo sido utilizada a logística no caso do trabalho citado. Notar que $G_{i}(p)=\pi_{i}^{n}$.

As abordagens de Hanemann e de Cameron, segundo Belluzzo Jr. (1995), conduzem a resultados idênticos se a especificação da função utilidade 
implicar em $\Delta v$ linear nos parâmetros e separável aditivamente numa função univariada de $p$.

Outra das medidas consideradas por Hanemann (1984) para estimar a medida de bem-estar é a média $(\bar{p})$ da distribuição dada por

$$
\bar{p}=E\left\{p^{\star}\right\}=\int_{0}^{\infty}[1-G(p)] d p
$$

No trabalho de Bishop \& Heberlein (1979), tomado como uma das bases pelo autor, computou-se a integral truncada em zero e no maior valor de $\rho$ proposto aos elementos da amostra.

Esta formulação não admite a existência de disposição a pagar negativa, isto é, obriga que $\pi^{s}\{p \leq 0\}=1$, significando que nenhum indivíduo da população afetada terá sua utilidade reduzida com o projeto. Esse pressuposto foi contestado por Johansson et al. (1989), que alertaram para o risco de viés introduzido pela truncagem da distribuição forçando $p \geq 0$ e por não estimar corretamente a média que, por definição, é dada por

$$
\bar{p}=\int_{0}^{\infty}[1-G(p)] d p-\int_{-\infty}^{0} G(p) d p
$$

Em réplica, Hanemann (1989) concordou, em parte, com a ressalva, lembrando que seu trabalho anterior não propõe a generalização do resultado. Assim, o modelo "completo" seria da forma simbolizada na Figura 6, em que a área mais clara representa o primeiro termo do lado direito da eq.( 36 ) e a área mais escura representa o segundo termo. 


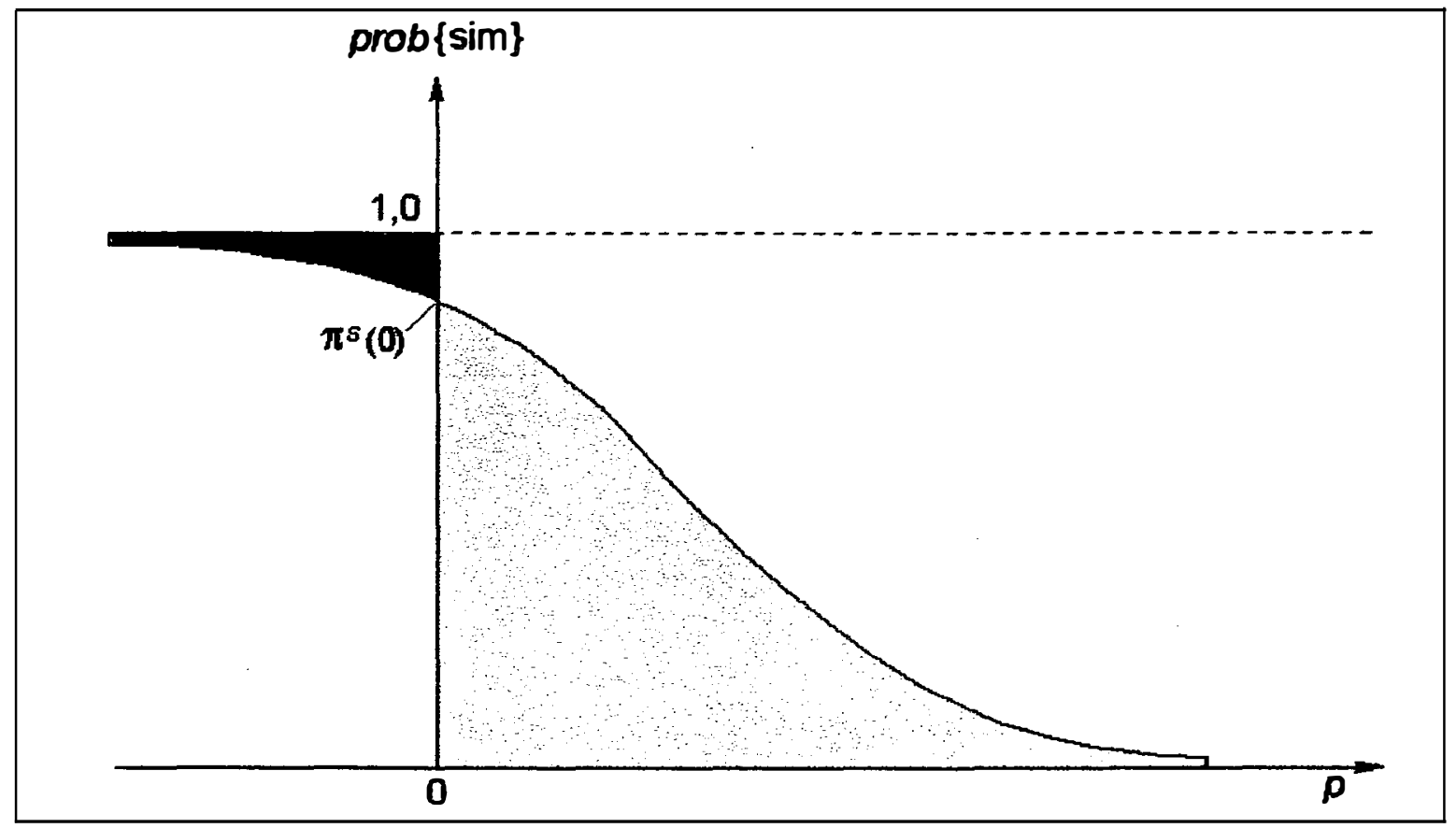

Figura 6. Representação de uma função de disposição a pagar.

Fonte: Hanemann (1989).

A função de distribuição, $G($.$) das eq.( 34$ ) a ( 36 ), assume diversas formas funcionais, encontrando-se na literatura exemplos de aplicação da normal, da log-normal, da logística e da log-logística (Reiser \& Shechter, 1999), entre outras menos citadas. As mais comumente encontradas, no entanto, são a normal e a logística. Para estimativa dos parâmetros incluídos no modelo, essas duas formulações resultam nos chamados modelos probito e logito, respectivamente (Bishop \& Heberlein, 1979; Hanemann, 1984; Hanemann, 1989; Bergstrom et al., 1990b; Cooper \& Loomis, 1992; Echeverría et al., 1995; Pate \& Loomis, 1997; González-Cabán \& Loomis, 1997; Loomis et al., 1998; Boland, 1999). Os resultados estimados por um e outro modelo diferem ligeiramente nas caudas da distribuição, mas o logito é considerado de computação mais simples (Judge et al., 1988; Loomis et al. 1998), motivos considerados neste trabalho para sua adoção, a exemplo do que fizeram Bishop \& Heberlein (1979) e Hanemann (1984), que deram ao modelo o formato 


$$
\pi^{s}=\left[1+\exp \left(\beta_{0}-\beta_{1} p\right)\right]^{-1}
$$

modelo também adotado por Bergstrom et al. (1990b) sob a forma

$$
\pi^{s}=\left[1+\exp \left(\beta_{0}-\beta_{1} p+\beta_{2} \omega\right)\right]^{-1}
$$

O modelo pode ser generalizado para

$$
\pi_{i}^{S}=1-G(\rho)=\left[1+\exp \left(\mathbf{x}_{i}^{\prime} \beta\right)\right]^{-1}
$$

onde $\mathbf{x}_{i}$ é o vetor que contém o valor proposto $p_{i}$ e as características individuais contidas no vetor $\omega_{i}$, como, por exemplo, sexo, idade, escolaridade e renda (Bowker \& Stoll, 1998).

O método de estimativa dos parâmetros pela razão de probabilidades, como em Loomis et al. (1998), poderia ser utilizado se houvesse um número razoável de repetições ao longo do tempo, no mínimo cinco ou seis (Judge et al., 1988, p.790), o que não ocorre na prática se há poucas - na maioria das vezes, apenas uma - observações sobre indivíduos com a mesma disposição a pagar e com as mesmas características individuais (Bowker \& Stoll, 1998). Neste caso, recomenda-se dar preferência ao método de maximização da função de verossimilhança $(L)$.

Se $G$ é a função logística, após algumas manipulações algébricas a eq.( 23 ) resulta em

$$
\frac{\partial \ln L}{\partial \boldsymbol{\beta}}=\sum_{i=1}^{m}\left(d_{i}^{n}-G_{i}\right) \mathbf{x}_{i}=\mathbf{0}
$$

em que $d_{i}^{n}=1-d_{i}^{s}$ ( $d_{i}^{s}=1$ em caso de resposta "sim"; $d_{i}^{s}=0$ se a resposta é "não"). Em adição, a estimativa da matriz de covariâncias é dada por

$$
\hat{V}(\hat{\boldsymbol{\beta}})=\left[-\sum_{i=1}^{m} \hat{G}_{i}\left(1-\hat{G}_{i}\right) \mathbf{x}_{i} \mathbf{x}_{i}^{\prime}\right]^{-1}
$$


com $\hat{G}_{i}$ sendo estimada pelo vetor $\hat{\beta}_{t+1}$ da eq.( 24 ). Para Judge et al. (1988) e Hanemann et al. (1991), a matriz da eq.( 41 ) é adequada para os testes estatísticos correlatos e para a construção de intervalos de confiança.

De posse da estimativa dos parâmetros, com base no modelo de diferença de utilidades, Hanemann $(1984 ;$ 1989) derivou a estimativa da disposição a pagar média como sendo dada por

$$
\bar{p}=\frac{1}{\hat{\beta}_{1}} \ln \left(1+e^{\hat{\beta}_{0}}\right)
$$

onde $\beta_{1}$ é o parâmetro da variável preço e $\beta_{0}$ é uma constante, se não há outras variáveis no modelo, ou o valor resultante da soma da constante estimada e do produto dos demais coeficientes pelas respectivas médias (González-Cabán \& Loomis, 1997). Este procedimento também foi adotado por Loomis et al. (1998) para estimativa da disposição a pagar média. Entretanto, essa formulação é baseada na eq. ( 35 ), com o pressuposto correlato de que $\pi^{s}\{p \leq 0\}=1$ e sob crítica de Johansson et al. (1989) considerada procedente, em parte, por Hanemann (1989).

Combinando as observações acima, o cálculo do valor esperado de $p^{\star}$ pode ser feito pela expressão (ver, por exemplo, Cooper \& Loomis, 1992):

$$
\bar{p}=-\frac{\hat{\beta}_{0}}{\hat{\beta}_{1}}
$$

em que $\hat{\beta}_{1}$ é a estimativa do parâmetro do preço e $\hat{\beta}_{0}$ é a constante do modelo, se não há outras variáveis incluídas, ou o valor resultante da soma da constante com $\bar{\omega}^{\prime} \hat{\beta}^{*}$, em que, para $j=2, \ldots, k, \quad \bar{\omega}=\left[\bar{x}_{j}\right]$ e $\hat{\beta}^{*}=\left[\beta_{j}\right]$. Obviamente, a eq. ( 43 ) dá o ponto médio tanto de $\pi^{s}$ como de $\pi^{n}$, isto é, o ponto em que $\pi^{s}=\pi^{n}=0,5$, lembrando, portanto, uma das medidas propostas por Hanemann (1984). 
Para o modelo de opção dicotômica com limite duplo, há quatro possibilidades de resposta (Hanemann et al., 1991; González-Cabán \& Loomis, 1997; Boland et al., 1999; Herriges, 1999, entre outros). Com base em Hanemann et al. (1991), sendo propostos ao indivíduo $i$ o preço inicial $p_{i}^{0}$ e um preço subseqüente dependendo da primeira resposta, se esta for "sim", oferece-se um preço mais alto $p_{i}^{a}>p_{i}^{0}$. Em relação ao verdadeiro valor da disposição a pagar $\left(\rho_{i}^{*}\right)$, a probabilidade de duas respostas positivas é dada por

$$
\begin{aligned}
& \pi_{i}^{s s}=\operatorname{prob}\{\operatorname{sim} \text { e sim }\}=\operatorname{prob}\left\{p_{i}^{0} \leq p_{i}^{*} \text { e } p_{i}^{a} \leq p_{i}^{*}\right\}=\operatorname{prob}\left\{p_{i}^{a} \leq p_{i}^{*}\right\} \\
& \pi_{i}^{s s}=1-G_{i}^{a}
\end{aligned}
$$

Simbologia adotada na eq.( 44 ) e subseqüentes: $G^{a}$ : distribuição contendo os valores $p^{a} ; G^{b}$ : distribuição contendo os valores $p^{b}$ (a serem definidos mais à frente); $G^{0}$ : distribuição contendo os valores $p^{0}$; ss: sobrescrito para indicar respostas na seqüência sim-sim; sn: respostas sim-não; $n s$ : respostas não-sim e nn: respostas não-não.

$\mathrm{Na}$ alternativa de a primeira resposta ser negativa, contrapõe-se à pessoa o valor $p_{i}^{b}<p_{i}^{0}$ e a probabilidade de duas respostas negativas é

$$
\begin{aligned}
& \pi_{i}^{n n}=\operatorname{prob}\{\text { não e não }\}=\operatorname{prob}\left\{p_{i}^{*}<p_{i}^{0} \text { e } p_{i}^{*}<p_{i}^{b}\right\}=\operatorname{prob}\left\{p_{i}^{*}<p_{i}^{b}\right\} \\
& \pi_{i}^{n n}=G_{i}^{b}
\end{aligned}
$$

A terceira possibilidade é "sim" seguido de "não":

$$
\begin{aligned}
& \pi_{i}^{s n}=\operatorname{prob}\{\text { sim e não }\}=\operatorname{prob}\left\{p_{i}^{0} \leq p_{i}^{*}<p_{i}^{a}\right\} \\
& \pi_{i}^{s n}=G_{i}^{a}-G_{i}^{0}
\end{aligned}
$$

A quarta possibilidade é "não" seguido de "sim":

$$
\pi_{i}^{n s}=\operatorname{prob}\{\text { não e sim }\}=\operatorname{prob}\left\{p_{i}^{b} \leq p_{i}^{*}<p_{i}^{0}\right\}
$$




$$
\pi_{i}^{n s}=G_{i}^{0}-G_{i}^{b}
$$

Neste caso, o logaritmo da função de verossimilhança é dado por

$$
\ln L=\sum_{i=1}^{m}\left[d_{i}^{s s} \ln \left(1-G_{i}^{a}\right)+d_{i}^{s n} \ln \left(G_{i}^{a}-G_{i}^{0}\right)+d_{i}^{n s} \ln \left(G_{i}^{0}-G_{i}^{b}\right)+d_{i}^{n n} \ln G_{i}^{b}\right]
$$

em que $d_{i}^{\text {ss }}=1$ se a combinação de respostas do indivíduo $i$ é "sim" e "sim" e igual a zero nas demais situações; $d_{i}^{\text {sn }}=1$ se a combinação é "sim" e "não" e zero nos demais casos, e assim por diante.

De maneira análoga à citada para o modelo com limite simples, a estimativa do vetor $\beta$ de parâmetros faz-se pela resolução do sistema $\partial \mathrm{I} n L \partial \beta=0$, aplicando-se algum método não-linear de estimação. Também de maneira análoga, a matriz de covariâncias é dada por $-E\left[\partial^{2} \ln L \partial \beta . \partial \beta^{\prime}\right]^{-1}$. Neste caso, entretanto, não é possível chegar-se a expressões elegantes como no caso das eq.( 40 ) e ( 41 ). No caso da estratégia utilizada por González-Cabán \& Loomis (1997), de propor, na ocorrência de respostas duplamente negativas, um terceiro valor considerado bastante baixo pelos autores (US\$1,00/ano), essa alternativa é incluída na eq.( 48 ) e derivações subseqüentes.

A estimativa do efeito marginal de uma variável explanatória sobre a probabilidade de resposta afirmativa não é direta, a partir dos coeficientes estimados (Judge et al., 1988), isto porque, para o modelo logito

$$
\frac{\partial \pi^{s}}{\partial x_{i j}}=-G(1-G) \beta_{j}
$$

faz com que o efeito sobre $\pi^{s}$ de uma variação em $x_{i j}$ dependa do valor de todas as variáveis. Entretanto, pela eq.( 49 ), como $0<G<1$, pode-se verificar que, pelo menos, o sinal do impacto pode ser antecipado: em sentido contrário ao da mudança no valor da variável, se $\beta_{j}>0$, e no mesmo sentido, se $\beta_{j}<0$. 
Para se estimar a magnitude do impacto, pode-se, por exemplo, tomar as características médias da população, se conhecidas, ou da amostra, a um dado valor da proposta de pagamento. Desta forma, $\overline{\mathbf{a}}=\left[\bar{x}_{j}\right]$, com $j=2, \ldots, k$, seria o vetor de características sócio-econômicas a considerar.

A qualidade do ajuste estatístico pode ser avaliada por algumas medidas. Para cada coeficiente em separado, isto é, para testar-se a hipótese $H_{0}: \beta_{j}=0$, o tradicional teste-t é usualmente aceito, embora haja outros métodos disponiveis na literatura (razão de verossimilhança, multiplicador de Lagrange, teste de Wald), não considerados neste estudo. Para o teste $t$, o valor estimado da variância assintótica $\left(\hat{\sigma}_{j}^{2}\right)$ é dado pelo elemento correspondente a $\beta_{j}$ na diagonal da matriz de covariâncias, e o valor resultante $t_{j}=\hat{\beta}_{j} / \hat{\sigma}_{j}$ é idêntico à raiz quadrada do valor qui-quadrado de Wald habitualmente fornecido pelos pacotes estatísticos usuais.

A significância da regressão pode ser avaliada, entre outras, pela razão de verossimilhança (Judge et al., 1988). A hipótese a testar é $H_{0}: \beta_{1}=\ldots=\beta_{k}=0$, isto é, mantém-se apenas a constante $\beta_{0}$ diferente de zero. A medida para o teste é dada por

$$
-2 \ln \lambda=2\left(\ln L_{u}-\ln L_{0}\right)
$$

em que $L_{u}$ é o valor da função de verossimilhança sem restrição, isto é, avaliado por $\hat{\boldsymbol{\beta}}$, e $L_{0}$ é o valor da função sob a restrição da hipótese $H_{0}$. O valor assim encontrado tem distribuição qui-quadrado $\operatorname{com} k-1$ graus de liberdade. Uma outra medida correlata é o chamado pseudo- $R^{2}$ (Judge et al., 1988), dado por

$$
R^{2}=1-\frac{\ln L_{u}}{\ln L_{0}}
$$


Para o modelo logito com limite duplo, porém, $L_{0}$ é indeterminada se calculada apenas com o valor da constante, conforme notado por Kanninen \& Khawaja (1995), isto porque,' na eq.( 48 ), $\beta_{1}=\ldots=\beta_{k}=0$ resulta em $G^{a}-G^{0}=0$ e $G^{0}-G^{b}=0$. Uma adaptação à medida do pseudo- $R^{2}$ foi proposta por Herriges (1999), em que, na eq.( 51 ), Lo é calculada com os valores estimados de $\beta_{0}$ (constante) e de $\beta_{1}$ (valor proposto), todos os demais parâmetros iguais a zero. Neste caso, a interpretação deve ser cautelosa, dado que o valor do pseudo- $R^{2}$ (e, por analogia, da razão de verossimilhança) está influenciado pela presença de $\beta_{1}$.

Por esta limitação, parece mais adequado recorrer-se a medidas do poder de previsão do modelo estimado com as observações da amostra. Assim, para o modelo com limite simples, seguindo-se Judge et al. (1988) ou Maddala (1988), considera-se correta a previsão se a probabilidade estimada para o evento observado é maior ou igual a 0,5 , isto é, diz-se que o modelo prevê corretamente uma ocorrência se a $\hat{\pi}_{i}^{s}>0,5$ corresponde uma resposta "sim", ou se a $\hat{\pi}_{i}^{n}>0,5$ corresponde uma resposta "não". A proporção de previsões corretas (número de acertos em relação ao total de observações) é tomada como uma medida da qualidade do ajuste estatístico.

Para o caso do modelo com limite duplo, o critério adotado neste trabalho é considerar como previsões corretas os casos em que o evento observado corresponde à maior probabilidade entre as quatro estimadas para cada observação. Para efeito prático de computação dos dados, pode-se adotar a sistemática a seguir. Para o indivíduo $i$, sendo $\rho_{i}$. vetor de codificação (1 para a respectiva resposta observada e zero para as demais); $\hat{\pi}_{i}$ : vetor das probabilidades estimadas; $c_{i}=1$ para previsão correta e $c_{i}=0$ em caso contrário, então, se $\rho_{i}{ }^{\prime} \hat{\pi}_{i}=\max \left(\hat{\pi}_{i}\right)$, computa-se $c_{i}=1$; em caso contrário, computa-se $c_{i}=0$. Fazendo-se $c=\Sigma c_{i}$, a razão entre $c$ e $n$ dá a proporção de previsões corretas do modelo. 
Neste trabalho, as variáveis incluídas são as seguintes:

$x_{1}$ : valores propostos aos entrevistados ( $R \$ /$ mês), portanto $x_{1}=p$;

$x_{2}$ : sexo do entrevistado (1: masculino; 0 : feminino);

$x_{3}$ : idade (anos);

$x_{4}$ : escolaridade (0: sem estudo; 1 : até o final do antigo primário; 2 : com nivel médio; 3: com nível superior);

$x_{5}$ : renda mensal familiar per capita (em salários mínimos);

$x_{6}$ : origem principal da renda (1: agricultura; 0 : demais).

Das variáveis acima, é notório que a renda não tem distribuição normal. O procedimento mais usual é usar-se o logaritmo da renda como variável explanatória. Assim, serão também ajustados modelos com $x_{5 a}=\ln \left(x_{5}\right)$.

Espera-se que o sinal seja positivo para o parâmetro de $x_{1}$ (redução da probabilidade de aceitação com o aumento do valor) e negativo para o de $x_{5}$. Para as demais variáveis, não há uma base prévia que permita formar expectativas dessa natureza.

Com os valores estimados da disposição a pagar, estudos posteriores poderão compor o fluxo de benefícios, usando técnicas tradicionais da análise benefício-custo. Este trabalho não inclui entre seus objetivos a estimativa dos custos envolvidos no projeto, o que poderá, eventualmente, ser do interesse de outras pesquisas. Apenas a título de ilustração, dados não publicados da Agropecuária Cresciumal, de Leme, SP, que desenvolve programa próprio de reposição de matas ciliares substitutas, fornecidos por Leme et al. (s/d), estimam, para uma densidade de plantio de 2.000 árvores por hectare, o custo privado de R\$ 1.393,47/ha, a preços de março de 1997. 
80.

\subsection{Levantamento dos dados}

A estratégia utilizada para o levantamento dos dados foi a de realizar entrevistas na rua, em locais sorteados com base nos mapas das cidades que compõem a área de estudo, isto é, cujos municípios englobam a bacia do rio Corumbataí (ver capítulo 4).

O tipo de entrevista proposto tende a ocorrer em situações de pouco conforto para o entrevistado e para o entrevistador. Por este motivo, julgou-se prudente que as entrevistas não fossem muito demoradas, não se abrindo mão, porém, das informações consideradas essenciais ao entendimento do cenário proposto. O levantamento de características sócio-econômicas cobriu apenas um pequeno número de variáveis consideradas fundamentais.

O "mercado hipotético" descrito a cada entrevistado consta do aumento da qualidade ambiental decorrente da reposição de matas ciliares, em quantidade proporcional aos recursos arrecadados, com o pagamento na forma de um valor $\mathrm{R} \$$ p/mês (tabela com os valores faz parte do Apêndice 3), a ser cobrado como adicional na conta de água de cada residência. Os recursos serão repassados às prefeituras, que se encarregarão de conduzir a implementação do projeto. Este mecanismo proposto tem o risco latente de viés do veículo de pagamento (confiança nos serviços de abastecimento de água, nas prefeituras), mas foi considerado o mais verossímil e de mais fácil entendimento pela população. Um grupo de trabalho que tem por objetivo estudar alternativas para a recuperação florestal do Corumbataí chegou a propor um mecanismo de reserva de $1 \%$ da tarifa de água para a finalidade prevista, por destinação em lei municipal, por destinação do serviço municipal de água e esgoto ou "paga voluntariamente pelos usuários" (Nassif \& Viana, 1998). O número de residências sem ligação de água é considerado desprezivel na região do estudo. Exceto em Charqueada, o déficit de 
atendimento da demanda por água tratada era inferior a 2\% em 1991 (SEADE, 1999), dado mais recente encontrado. $\mathrm{Na}$ amostra, quando ocorreram casos de pessoas morando em residências sem ligação de água, bem como de entrevistados residindo fora dos municípios considerados na área de estudo, as respectivas observações foram excluídas da amostra.

Pelo motivo exposto acima, os indivíduos econômicos são as residências (domicílios). Este critério depende de um forte pressuposto: o de que qualquer membro, com 20 anos ou mais (idade considerada como mínima para ser aceito na amostra), é capaz e tem autonomia para responder pela família num assunto desta natureza.

\subsection{Caracterização da área de estudo}

A bacia do rio Corumbataí situa-se entre as latitudes $22^{\circ} 05^{\prime} \mathrm{S}$ e $22^{\circ} 30^{\prime} \mathrm{S}$ e longitudes $47^{\circ} 30^{\prime} \mathrm{WG}$ e 47050'WG. A área de drenagem é de $1.710 \mathrm{~km} 2$ (Koffler, 1993), ao passo que a área total dos municípios é de $2.900 \mathrm{~km} 2$ (SEADE, 1995). A área de estudo faz parte dos municípios de Analândia, Charqueada, Corumbataí, Ipeúna, Piracicaba, Rio Claro e Santa Gertrudes (ver ilustração no Apêndice 1). O município de Itirapina também é incluído por Koffler (1993) e por López (1998), mas não consta dos documentos do Comitê das Bacias Hidrográficas dos Rios Piracicaba, Capivari e Jundiaí - CBH-PCJ (São Paulo, 1995) e não será considerado neste trabalho. O rio Corumbataí e seus formadores são tributários da bacia hidrográfica do rio Piracicaba.

O clima é do tipo Cwa subtropical, classificação de Koepen, com a temperatura média do mês mais quente superior a $22^{\circ} \mathrm{C}$ (Koffler, 1993).

Através de fragmentos remanescentes, Troppmair \& Machado (1974) classificaram os tipos de vegetação ciliar da área deste estudo, variáveis desde herbáceas até arbóreas, de acordo com a disponibilidade de água no solo e 
82.

com a insolação, fatores estes influenciados pela topografia. A largura da faixa de vegetação tem influência do traçado do rio, sendo mais larga nos arcos internos das curvas. As estimativas de Nassif \& Viana (1998) são de que a bacia do Corumbataí tem cerca de 11.500 hectares que deveriam ser ocupados com mata ciliar, além de 17.500 hectares de áreas de encostas e de complementação da área de reserva florestal legal. Ainda mais, assinala a necessidade de recuperação dos 5.000 hectares remanescentes de florestas naturais, em boa parte degradadas. Alguns projetos-piloto de recuperação da mata ciliar vêm sendo desenvolvidos nos municípios de Piracicaba e Rio Claro, envolvendo pesquisas na área florestal (Viana \& Mendes, 1998).

As terras agrícolas estão alocadas a cerca de 4.600 unidades de produção, com área média de 55,5 ha. Do total de unidades, $89,5 \%$ têm área total de até 100 hectares (com base em Pino et al., 1997). Os dados de uso do solo estão na Tabela 2. A vegetação natural (não especificada) ocupa cerca de $7,2 \%$ da área total dos municípios. As atividades agropecuárias predominantes são a pecuária (com as pastagens ocupando $39,7 \%$ da área) e culturas semi-perenes $(35,2 \%$, representadas principalmente pela cana-deaçúcar).

Para a área de drenagem da bacia do Corumbataí, a estimativa é de $6 \%$ de mata natural (São Paulo, 1990). Este percentual é próximo dos 6,1\% anotados por Koffler (1993), se incluído 1,2\% de cerrado. Uma ilustração do uso do solo na área do projeto pode ser vista no Apêndice 2.

O abastecimento urbano de água é feito, em sua maior parte, a partir de captação profunda (poços) ou superficial em corpos d'água da bacia do Corumbataí. A água do rio Corumbataí é considerada de boa qualidade (média de 4,0 a 6,0 mg/L de oxigênio dissolvido) quando comparada, por exemplo, à água do rio Piracicaba, que nos períodos de estiagem apresenta em torno de 1,0 mg/L de oxigênio dissolvido (SEMAE, 1999). A demanda de água estimada e projetada está na Tabela 3. 
Tabela 2. Uso do solo nos municipios da bacia do Corumbataí, 1995-96 (em mil ha).

\begin{tabular}{|c|c|c|c|c|c|c|c|c|c|}
\hline \multirow[b]{2}{*}{ Uso do solo } & \multirow{2}{*}{$\begin{array}{l}\text { Ana- } \\
\text { lândia } \\
\text { (ANA) }\end{array}$} & \multirow{2}{*}{$\begin{array}{r}\text { Char- } \\
\text { queada } \\
\text { (CHA) }\end{array}$} & \multirow{2}{*}{$\begin{array}{r}\text { Corum- } \\
\text { batai } \\
\text { (COR) }\end{array}$} & \multirow{2}{*}{$\begin{array}{l}\text { Ipeúna } \\
\text { (IPE) }\end{array}$} & \multirow{2}{*}{$\begin{array}{r}\text { Pira- } \\
\text { cicaba } \\
\text { (PIR) }\end{array}$} & \multirow{2}{*}{$\begin{array}{r}\text { Rio } \\
\text { Claro } \\
\text { (RCL) }\end{array}$} & \multirow{2}{*}{$\begin{array}{c}\text { Sta.Ger- } \\
\text { trudes } \\
\text { (STG) }\end{array}$} & \multicolumn{2}{|c|}{ Total } \\
\hline & & & & & & & & Área & $\%$ \\
\hline Cult. permanente & 4,3 & 0,0 & 2,3 & 0,2 & 1,9 & 3,1 & 0,4 & 12,2 & 4,8 \\
\hline Cult.semi-perene & 3,0 & 9,9 & 2,8 & 5,1 & 51,0 & 11,7 & 6,2 & 89,8 & 35,2 \\
\hline Cult.anual & 0,6 & 0,1 & 0,8 & 0,3 & 3,0 & 1,6 & 0,4 & 6,8 & 2,7 \\
\hline Pastagem & 17,1 & 4,0 & 15,0 & 9,4 & 46,0 & 9,1 & 0,8 & 101,3 & 39,7 \\
\hline Reflorestam. & 2,8 & 0,3 & 1,9 & 0,2 & 1,5 & 3,6 & 0,1 & 10,3 & 4,0 \\
\hline Veget.natural & 2,9 & 2,3 & 2,4 & 1,5 & 6,2 & 2,5 & 0,8 & 18,5 & 7,2 \\
\hline Inaproveitada & 0,2 & 0,1 & 0,1 & 0,3 & 3,9 & 0,3 & 0,2 & 5,3 & 2,1 \\
\hline Inaproveitável & 0,7 & 0,5 & 0,2 & 0,4 & 2,0 & 1,5 & 0,0 & 5,3 & 2,1 \\
\hline Complementar & 0,5 & 0,3 & 0,7 & 0,2 & 2,7 & 1,2 & 0,2 & 5,8 & 2,3 \\
\hline Total & 32,2 & 17,5 & 26,2 & 17,4 & 118,3 & 34,6 & 9,0 & 255,3 & 100,0 \\
\hline
\end{tabular}

Fonte: dados básicos em Pino et al (1997).

Obs.: eventuais discrepâncias nos somatórios devem-se a arredondamentos.

Tabela 3. Demanda estimada de água, 1990 e $2000\left(\mathrm{~m}^{3} / \mathrm{s}\right)$.

\begin{tabular}{lccccccr}
\hline Uso & \multicolumn{3}{c}{ Vazão de captação } & & \multicolumn{3}{c}{ Uso consuntivo } \\
\cline { 2 - 4 } \cline { 6 - 8 } & 1990 & 2000 & Cresc.\% & & 1990 & 2000 & Cresc.\% \\
\hline Industrial & 1,073 & 1,160 & 8 & & 1,046 & 1,130 & 8 \\
Urbana & 0,959 & 1,292 & 35 & & 0,580 & 0,770 & 33 \\
Agropecuária & 0,341 & 0,399 & 17 & & 0,341 & 0,399 & 17 \\
\hline \multicolumn{1}{c}{ Total } & 2,373 & 2,851 & 20 & & 1,967 & 2,299 & 17 \\
\hline
\end{tabular}

Fonte: São Paulo (1990).

Obs.: eventuais discrepâncias nos somatórios devem-se a arredondamentos.

Alguns dados sócio-econômicos da área de estudo estão anotados na Tabela 4 à Tabela 8 . A população afetada pela bacia do Corumbataí foi estimada em cerca de 493 mil pessoas no ano de 1996 (IBGE, 1997), conforme Tabela 4. Os habitantes da zona rural são cerca de $4,6 \%$ da população total da região, proporção esta menor que a do estado de São Paulo, que tem 6,9\% de sua população vivendo fora das cidades. 
84.

Tabela 4. População residente nos municípios da bacia do rio Corumbataí, por local de domicílio e sexo, 1996.

\begin{tabular}{|c|c|c|c|c|c|c|c|c|c|}
\hline Domicilio & Sexo $^{(1)}$ & ANA & $\mathrm{CHA}$ & COR & IPE & PIR & $\mathrm{RCL}$ & STG & Total \\
\hline \multicolumn{2}{|c|}{$N^{0}$ de habitantes } & 3446 & 12572 & 3530 & 3341 & 302886 & 153389 & 13605 & 492769 \\
\hline \multirow[t]{2}{*}{ Urbano } & $H(\%)$ & 33,5 & 44,2 & 21,5 & 40,1 & 47,5 & 47,4 & 50,4 & 47,1 \\
\hline & $M(\%)$ & 30,6 & 43,2 & 21,9 & 39,9 & 48,5 & 49,5 & 46,7 & 48,3 \\
\hline \multirow[t]{2}{*}{ Rural } & $H(\%)$ & 19,1 & 6,6 & 30,5 & 11,0 & 2,1 & 1,6 & 1,6 & 2,4 \\
\hline & $M(\%)$ & 16,8 & 6,0 & 26,1 & 9,0 & 1,9 & 1,5 & 1,4 & 2,2 \\
\hline Total (\%) & & 100,0 & 100,0 & 100,0 & 100,0 & 100,0 & 100,0 & 100,0 & 100,0 \\
\hline
\end{tabular}

Fonte: IBGE (1997).

(1) $\mathrm{H}$ : homens; M: mulheres.

Obs.: eventuais discrepâncias nos somatórios devem-se a arredondamentos.

Tabela 5. Número de domicílios particulares permanentes dos municípios que contêm a bacia do rio Corumbataí, 1996

\begin{tabular}{rrrrrrrr}
\hline ANA & CHA & COR & IPE & PIR & RCL & STG & Total \\
\hline 900 & 3236 & 945 & 899 & 81573 & 42021 & 3564 & 133138 \\
0,7 & 2,4 & 0,7 & 0,7 & 61,3 & 31,6 & 2,7 & $\%$ total \\
\hline
\end{tabular}

Fonte: SEADE (1999).

Tabela 6. Distribuição etária da população dos municípios que contêm a bacia do rio Corumbataí, 1996. Em percentagem.

\begin{tabular}{rrrrrrrrrr}
\hline Faixa etária & ANA & CHA & COR & \multicolumn{1}{c}{ IPE } & PIR & RCL & STG & Total & Total > 20 \\
\hline $0-14$ & \multicolumn{1}{c}{30} & 31 & 31 & 30 & 27 & 26 & 28 & 27 & \\
$15-19$ & 10 & 9 & 10 & 9 & 10 & 10 & 10 & 10 & \\
$20-24$ & 9 & 9 & 8 & 9 & 9 & 9 & 11 & 9 & 14 \\
$25-39$ & 23 & 24 & 22 & 23 & 25 & 24 & 26 & 25 & 39 \\
$40-59$ & 19 & 18 & 18 & 18 & 20 & 20 & 17 & 20 & 31 \\
$60+$ & 9 & 9 & 11 & 10 & 9 & 11 & 8 & 10 & 16 \\
\hline
\end{tabular}

Fonte: SEADE (1999).

Obs.: eventuais discrepâncias nos somatórios devem-se a arredondamentos.

Os dados da Tabela 5 são uma das bases para o cálculo da proporcionalidade na amostra e para a generalização dos dados. Nota-se que 
as cidades de Piracicaba e Rio Claro respondem por 92,9\% do total de domicílios permanentes da região objeto de estudo.

Tabela 7. Anos de estudo do chefe do domicílio e taxa de analfabetismo de adultos nos municípios que contêm a bacia do rio Corumbataí, 1996

\begin{tabular}{rrrrrrrrr}
\hline & ANA & CHA & COR & IPE & PIR & RCL & STG & Média* $^{*}$ \\
\hline $\begin{array}{r}\text { Anos de } \\
\text { estudo }\end{array}$ & 4,78 & 4,70 & 4,20 & 4,39 & 6,66 & 6,73 & 4,77 & 6,54 \\
$\begin{array}{r}\text { Analfabe- } \\
\text { tismo (\%) }\end{array}$ & 13,94 & 13,24 & 14,88 & 14,31 & 7,67 & 7,76 & 13,02 & 8,11 \\
\hline
\end{tabular}

* Ponderada pelo número de domicílios (Tabela 5).

Fonte: SEADE (1999).

Tabela 8. Niveis de renda dos chefes de domicílio dos municípios que contêm a bacia do rio Corumbataí, 1996. Em percentagem.

\begin{tabular}{rrrrrrrrr}
\hline Renda (SM) & ANA & CHA & COR & IPE & PIR & RCL & STG & Média* $^{*}$ \\
\hline Até 1 & 25 & 13 & 20 & 18 & 10 & 11 & 12 & 10,9 \\
1 a 2 & 32 & 26 & 31 & 35 & 19 & 22 & 23 & 21,2 \\
2 a 5 & 30 & 41 & 32 & 30 & 38 & 39 & 45 & 39,3 \\
5 a 10 & 9 & 13 & 10 & 10 & 19 & 16 & 13 & 17,9 \\
Mais de 10 & 5 & 5 & 4 & 5 & 12 & 9 & 4 & 10,7 \\
\hline
\end{tabular}

SM: salário mínimo mensal.

* Ponderada pelo número de domicílios (Tabela 5).

Fonte: SEADE (1999).

Obs.: discrepâncias nos somatórios nos dados originais.

Pela Tabela 8, a grande maioria dos chefes de domicílio, mais de $70 \%$, têm renda mensal de até cinco salários mínimos, e menos de $11 \%$ percebem mais de dez salários mínimos. Esses dados, porém, são ilustrativos, dado que, para a variável incluída no modelo, renda mensal per capita, não se localizaram dados relativamente recentes para os municípios da área de estudo. 


\section{RESULTADOS E DISCUSSÃO}

Este capítulo procura relatar os principais procedimentos adotados na condução da pesquisa de campo, apresentar os resultados obtidos e discuti-los à luz da teoria apresentada nos capítulos 2 e 3.

A pesquisa de campo, incluindo pré-teste, ocorreu nos meses de outubro e novembro e na primeira semana de dezembro de 1999, nos sete municípios que englobam a área deste estudo (bacia do rio Corumbataí): Analândia, Charqueada, Corumbataí, Ipeúna, Piracicaba, Rio Claro e Santa Gertrudes.

\subsection{Condução da pesquisa de campo}

Os entrevistadores, quatro moças e sete rapazes, foram recrutados entre os estudantes de graduação em Engenharia Agronômica do Centro de Ciências Agrárias da Universidade Federal de São Carlos (UFSCar), campus Araras, SP. Essa equipe operacional do projeto passou por algumas etapas de capacitação, como discussão do problema e da metodologia; comportamento durante a abordagem e a entrevista; procedimento para escolha aleatória de pessoas a serem abordadas; sessão de interpretação do conteúdo das versões preliminares do material informativo (texto-resumo na forma de "roteiro de entrevista", figura e questionário).

A etapa seguinte da capacitação consistiu na aplicação do pré-teste do material (informação e questionário). Nessa etapa, a escolha dos locais em 
cada cidade foi arbitrária, sem maior rigor quanto à sua aleatoriedade. Deste procedimento resultaram 171 entrevistas, nas sete cidades da área de estudo.

Realizou-se, então, um encontro da equipe, em que se discutiram o material obtido e a experiência vivenciada, visando reduzir falhas de conteúdo e comportamento, bem como padronizar os procedimentos dos entrevistadores. Dessa avaliação resultou o material definitivo utilizado na pesquisa, apresentado no Apêndice 3.

O dimensionamento da pesquisa definitiva partiu de um referencial de 900 entrevistas, a serem distribuídas entre as cidades proporcionalmente a seus números de domicílios permanentes (dados pela Tabela 5), mas predeterminando-se um número mínimo de 15 entrevistas naquelas cidades em que a respectiva quota resultou menor. Das sete cidades envolvidas, apenas Piracicaba e Rio Claro apresentam números relativamente grandes de entrevistas necessárias. A escolha dos locais das entrevistas, nessas duas cidades, fez-se com base em mapas disponíveis em livrarias. Cada mapa foi dividido em quadriláteros numerados e, dentre estes, cada entrevistador sorteou cinco. Disso resultaram 15 locais de Rio Claro e 30 locais de Piracicaba. Para as outras cinco cidades, os entrevistadores foram orientados a se deslocar de um lado a outro da cidade, dedicando mais tempo aos pontos de maior fluxo de pessoas. Uma falha deste trabalho é que o número de entrevistas em cada local foi estabelecido arbitrariamente. Durante a fase de levantamento dos dados, manteve-se contato contínuo com os entrevistadores, em grupo ou individualmente, para monitoramento da pesquisa e recepção do material à medida que foi sendo produzido. Algumas poucas entrevistas foram conduzidas pelo autor deste trabalho. Os números de entrevistas realizadas e de pessoas que se recusaram a participar da pesquisa estão anotados na Tabela 9. 
88.

Como curiosidade, registre-se que, durante a fase de levantamento dos dados, ocorreu um incidente na cidade de Piracicaba que, eventualmente, poderia ter comprometido toda a pesquisa. $O$ fato está ilustrado no Apêndice 4.

\subsection{Resultados sem exclusão dos protestos}

\subsubsection{Perfil da amostra}

Dos 991 questionários produzidos, foram descartados 61, por preenchimento incompleto (a causa mais freqüente foi a não informação da renda familiar) ou por requisito metodológico (residência fora da área de estudo, idade inferior a 20 anos, residência sem conta de água etc.). Portanto, a amostra remanescente compõe-se de 930 observações. O resumo dessas informações está na Tabela 9.

Tabela 9. Número de entrevistas realizadas e representatividade por município.

\begin{tabular}{|c|c|c|c|c|c|c|}
\hline \multirow[t]{2}{*}{ Municipio } & \multirow[t]{2}{*}{ Recusas } & \multirow{2}{*}{$\begin{array}{l}\text { Total de } \\
\text { observ }\end{array}$} & \multirow{2}{*}{ Excluidas* } & \multicolumn{2}{|c|}{ Utilizadas } & \multirow{2}{*}{$\begin{array}{l}\text { \% domi- } \\
\text { cílios }\end{array}$} \\
\hline & & & & $n^{0}$ & $\%$ & \\
\hline Analândia & 0 & 15 & 0 & 15 & 1,6 & 0,7 \\
\hline Charqueada & 6 & 27 & 1 & 26 & 2,8 & 2,4 \\
\hline Corumbatai & 2 & 15 & 0 & 15 & 1,6 & 0,7 \\
\hline Ipeúna & 0 & 16 & 0 & 16 & 1,7 & 0,7 \\
\hline Piracicaba & 126 & 599 & 56 & 543 & 58,4 & 61,2 \\
\hline Rio Claro & 41 & 304 & 4 & 300 & 32,3 & 31,6 \\
\hline Sta.Gertrudes & 0 & 15 & 0 & 15 & 1,6 & 2,7 \\
\hline Total & 175 & 991 & 61 & 930 & 100,0 & 100,0 \\
\hline
\end{tabular}

* Por preenchimento incompleto ou por pressuposto metodológico.

Fonte: dados da pesquisa e Tabela 5.

Da análise da Tabela 9, destaquem-se dois pormenores. O primeiro refere-se ao número de observações aproveitáveis, que mantém proporcionalidade razoável com o número de domicílios dos municípios de 
Charqueada, Piracicaba e Rio Claro. Nos casos de Analândia, Corumbataí e Ipeúna, a discrepância resulta da imposição de um número mínimo de 15 entrevistas por município. Essas considerações têm o único intuito de relatar detalhes da condução do projeto, dado que, para se atingir o objetivo central valor atribuído pela população às matas ciliares no âmbito da bacia do rio Corumbataí - preocupações dessa natureza são secundárias se a amostra total for representativa.

O segundo aspecto a ressaltar, na Tabela 9 , é a proporção de pessoas (cerca de 15\%) que se recusaram a participar da pesquisa, fato ligado diretamente à técnica de levantamento adotada, através de entrevistas na rua, em que o procedimento aleatório de escolha dos indivíduos a serem abordados inexoravelmente se depara com situações em que a pessoa está "com pressa".

Por uma indesejável restrição operacional, as entrevistas só puderam ser realizadas de modo a não comprometer as atividades escolares dos entrevistadores (que estudam numa cidade fora da área pesquisada), tendo sido os fins-de-semana, os feriados e uma semana de recesso estudantil os períodos mais utilizados. No entanto, essa restrição acabou contribuindo em favor da pesquisa. Pelo depoimento de diversos entrevistadores, as pessoas mostram-se mais cordatas e cooperativas quando não estão sob a pressão de compromissos profissionais ou domésticos, o que é mais provável de ocorrer em finais de tarde, sábados à tarde, domingos e feriados. Ressalte-se que todo este parágrafo não tem pretensão metodológica, tratando-se de meras observações ilustrativas.

A Tabela 10 apresenta a tabulação das percentagens, na amostra, da ocorrência de pessoas do sexo feminino, das faixas etárias e das faixas de renda mensal per capita (medida em salários mínimos). Para os dois primeiros itens, apresentam-se dados da população, para efeito comparativo, embora com defasagem de alguns anos. Para o caso da renda, não se localizaram dados populacionais adequados em nível de município, para comparação. Por 
90.

inspeção, nota-se que a representação feminina é um pouco menor na amostra $(48,7 \%)$ do que se observa na população $(50,5 \%)$, uma diferença tolerável, ainda mais se lembrado que na amostra só foram admitidas pessoas com 20 anos de idade ou mais. Na amostra, a distribuição etária deixou a desejar, com - estrato de 20 a 24 anos tendo sido sub-representado, ficando com representação excessiva a faixa de 40 a 59 anos. A renda mensal per capita, no nivel da amostra, é de até dois salários mínimos para $57 \%$ das famílias, e apenas $1,7 \%$ percebem mais de dez salários mínimos. Para efeito de comparação, não há dados populacionais recentes. A Tabela 8 , apresentada no capítulo 3, mostra dados de 1996 da renda mensal do chefe do domicílio, o que não permite comparação por carecer de informações complementares, como renda de outros membros da família e tamanho da família por estrato de renda.

Tabela 10. Perfil da amostra (em \%): sexo, idade e renda.

\begin{tabular}{|c|c|c|c|c|c|c|c|c|c|c|}
\hline & \multirow{2}{*}{$\begin{array}{l}\text { Sexo } \\
\text { Fem }\end{array}$} & \multicolumn{4}{|c|}{ Idade (anos) } & \multicolumn{5}{|c|}{ Renda mensal per capita (SM) } \\
\hline & & $20-24$ & $25-39$ & $40-59$ & $60+$ & $<1$ & $1-2$ & $2-5$ & $5-10$ & $>10$ \\
\hline Amostra & 48,7 & 7,7 & 36,9 & 40,6 & 14,8 & 18,0 & 39,0 & 33,0 & 8,3 & 1,7 \\
\hline População & 50,5 & 14,1 & 39,0 & 31,3 & 15,6 & nd & nd & nd & nd & no \\
\hline
\end{tabular}

SM: salário mínimo mensal (R\$ 136,00); nd: não disponível.

Fonte: dados da pesquisa, Tabela 4 e Tabela 6.

A média amostral da variável escolaridade é de 5,8 anos de estudo, admitindo-se quatro anos como sendo a duração do ciclo básico (correspondente ao antigo primário), oito anos para o nível médio e cinco anos para o nivel superior. $O$ dado disponivel para comparação é a escolaridade do chefe da família (Tabela 7), estimada em 6,5 anos de estudo, no ano de 1996. $O$ índice zero (sem estudo) ocorreu em 4,1\% da amostra (contra $8,1 \%$ de chefes de domicílio analfabetos estimados para a população em 1996). A agricultura como origem principal da renda familiar foi mencionada por $2,6 \%$ 
dos entrevistados. Não há dados recentes para comparação com a população da área de estudo.

As respostas às propostas de pagamento pela reposição de matas ciliares na bacia do Corumbataí estão sumarizadas na Tabela 11, especificadas por valores. Verifica-se que, do total da amostra, 35\% dos entrevistados concordaram com o preço inicial, mas apenas $11 \%$ mantiveram resposta positiva para um preço mais alto. Por outro lado, $9 \%$ dos entrevistados concordaram com um preço mais baixo, após recusarem o preço inicial proposto. No geral, o resultado foi o seguinte: $11,3 \%$ de respostas "simsim", $23,6 \%$ de respostas "sim-não", 7,1\% de respostas "não-sim" e 58,0\% de respostas "não-não".

Tabela 11. Respostas aos preços propostos sem excluir protestos.

\begin{tabular}{|c|c|c|c|c|c|c|c|c|c|}
\hline \multicolumn{3}{|c|}{ Preços (R\$ /mês) } & \multirow[t]{2}{*}{ Amostra } & \multicolumn{2}{|c|}{$1^{\text {a }}$ resposta } & \multicolumn{4}{|c|}{ Respostas combinadas } \\
\hline Inicial & Maior & Menor & & $S$ & $\mathbf{N}$ & SS & SN & NS & NN \\
\hline 0,50 & 1,00 & 0,10 & 193 & 152 & 41 & 73 & 79 & 11 & 30 \\
\hline 2,00 & 3,00 & 1,00 & 189 & 100 & 89 & 24 & 76 & 29 & 60 \\
\hline 5,00 & 7,00 & 3,00 & 180 & 47 & 133 & 8 & 39 & 21 & 112 \\
\hline 10,00 & 15,00 & 7,00 & 196 & 25 & 171 & 0 & 25 & 4 & 167 \\
\hline 30,00 & 50,00 & 15,00 & 172 & 0 & 172 & 0 & 0 & 1 & 171 \\
\hline & Totais & & 930 & 324 & 606 & 105 & 219 & 66 & 540 \\
\hline
\end{tabular}

S: sim; N: não.

Fonte: dados da pesquisa.

O preço mais alto aceito foi $R \$ 15,00$, com apenas uma ocorrência. Com base na Tabela 11 , cerca de $42 \%$ dos entrevistados pagariam alguma quantia para a recuperação da mata ciliar, enquanto que a maioria (58\%) não pagaria qualquer dos preços propostos (respostas "não-não"). Desses, chama a atenção a ocorrência de $15,5 \%$ na faixa de preços mais baixos, isto é, de pessoas que não concordam em pagar $\mathrm{R} \$ 0,10$ ao mês pela implementação do projeto. Os motivos alegados para a não concordância com nenhum dos dois preços propostos (respostas "não-não") estão listados na Tabela 12, com as 
92.

respectivas ocorrências. Os dados dessa tabela não permitem confronto com os da Tabela 11, pois admitiu-se mais de uma resposta por entrevistado.

Tabela 12. Justificativas para respostas "não" e "não".

\begin{tabular}{llrrrrrr}
\hline \multirow{2}{*}{ Causas de "não-não" } & \multicolumn{3}{c}{ Preço inicial (R\$ /mês) } & Total \\
\cline { 2 - 7 } & 0,50 & 2,00 & 5,00 & 10,00 & 30,00 & \\
\hline 1 & O valor é muito alto & 1 & 7 & 35 & 90 & 133 & 266 \\
2 & O problema é do governo & 5 & 14 & 17 & 12 & 15 & 63 \\
3 & O problema é dos agricultores & 0 & 3 & 3 & 5 & 4 & 15 \\
4 & Não confio no uso dos recursos & 13 & 14 & 28 & 37 & 19 & 111 \\
5 & Não acho o assunto importante & 0 & 1 & 4 & 4 & 3 & 12 \\
6 & Preciso de mais tempo para pensar & 0 & 2 & 6 & 3 & 2 & 13 \\
7 & O projeto vai me dar prejuizo & 2 & 2 & 2 & 4 & 2 & 12 \\
8 & Já pago muitos impostos e taxas & 12 & 21 & 35 & 44 & 30 & 142 \\
9 & Outros motivos & 1 & 4 & 4 & 2 & 3 & 14 \\
\hline
\end{tabular}

Obs.: somatórios não coincidentes com a Tabela 11 ( mais de uma resposta por entrevistado).

Fonte: dados da pesquisa.

O motivo $n^{\circ} 1$ ("O valor é muito alto") tem distribuição coerente, crescendo o número de ocorrências com o aumento do preço. Para o motivo n०8 ("Já pago muitos impostos e taxas"), segundo mais citado pelos entrevistados, a conclusão não é tão clara. De qualquer forma, considerou-se que esses dois itens têm alguma relação com a restrição orçamentária individual. Os itens 2 ("O problema é do governo"), 3 ("O problema é dos agricultores") e 4 ("Não confio no uso dos recursos") procuraram captar atitudes de protesto, tendo resultado em 189 manifestações nesse sentido. As manifestaçōes anotadas no item 4 parecem indicar a presença de viés do veículo de pagamento, isto é, valor adicional na conta de água (administrado por agência oficial de água e esgoto) e repasse dos recursos às prefeituras. $O$ item n 5 ("Não acho o assunto importante") procurou captar aquela parcela da população que não entende ter sua utilidade alterada pela implementação do 
93.

projeto. $O$ item 7 ("O projeto vai me dar prejuizo"), alegado por 12 entrevistados, tentou captar redução da utilidade individual, na linha da preocupação manifestada por Johansson et al. (1989) em relação ao modelo de Hanemann (1984). As 13 ocorrências no item 6 ("Preciso de mais tempo para pensar") refletem um possivel problema de tempo escasso para o entrevistado decidir sobre a transação.

Pelo exposto, transparece a importância dos relativamente baixos niveis de renda da população e da falta de confiança no uso dos recursos por parte do governo na não disposição a pagar pela recuperação das matas ciliares da bacia do rio Corumbataí.

\subsubsection{Estimativas do modelo}

Para as estimativas estatísticas, utilizou-se um programa computacional de cálculo matemático que permite a introdução de rotinas. Deuse preferência a este procedimento por dois motivos principais: (i) os pacotes estatísticos específicos não são de disponibilidade generalizada e exigem aprendizado específico; (ii) a aplicação passo a passo das equações permitiu aumentar o aprendizado e o entendimento do modelo. Para o modelo logito de limite simples (utilizando os valores iniciais propostos na pesquisa), os resultados obtidos foram confrontados com os obtidos por meio de um programa estatístico convencional ${ }^{20}$, tendo-se verificado perfeita coincidência das estimativas (parâmetros, desvios-padrões, testes de significância e outros), com precisão no nível de décimo de milésimo. Para o modelo logito de limite duplo, os dados estimados não foram confrontados com os obtidos em programa estatístico usual, tendo-se utilizado os dados obtidos como descrito

\footnotetext{
${ }^{20}$ Por cortesia do Prof.Dr. Norberto Antonio Lavorenti, do Centro de Ciências Agrárias da UFSCar.
} 
anteriormente, isto é, criando-se rotinas de processamento das fórmulas e equações do modelo.

A estimativa do vetor de parâmetros $(\hat{\beta})$ que maximiza a verossimilhança $(L)$ fez-se com o emprego do método de Newton-Raphson, formulado na eq.( 24 ). Para tanto, desenvolveu-se um rotina utilizando-se o software Matlab 4.0 para os modelos com limite simples e limite duplo ${ }^{21}$, em que pese haver, para o primeiro caso, diversos pacotes estatísticos comerciais disponiveis.

As estimativas para toda a amostra, sem excluir os protestos, obtidas pelo procedimento descrito, estão anotadas na Tabela 13.

Tabela 13. Estimativas dos modelos, sem excluir manifestações de protesto.

\begin{tabular}{|c|c|c|c|c|c|c|c|c|c|}
\hline \multirow[b]{2}{*}{$j$} & \multirow[b]{2}{*}{ Variável } & \multicolumn{4}{|c|}{ Limite simples } & \multicolumn{4}{|c|}{ Limite duplo } \\
\hline & & $\hat{\beta}_{j}$ & $\hat{\sigma}_{j}$ & Wald $\chi^{2}$ & & $\hat{\beta}_{j}$ & $\hat{\sigma}_{j}$ & Wald $\chi^{2}$ & \\
\hline 0 & Constante & $-2,3265$ & 0,4336 & 28,7937 & $*$ & $-2,1612$ & 0,3709 & 33,9451 & $\star \star$ \\
\hline 1 & Preço & 0,3509 & 0,0293 & 143,3231 & $\star \star$ & 0,5821 & 0,0287 & 411,9735 & $\star \star$ \\
\hline 2 & Sexo & 0,1040 & 0,1733 & 0,3597 & ns & $-0,0360$ & 0,1514 & 0,0567 & ns \\
\hline 3 & Idade & 0,0266 & 0,0066 & 16,0173 & $\star *$ & 0,0231 & 0,0057 & 16,3185 & $\star \star$ \\
\hline 4 & Escolaridade & 0,1739 & 0,1400 & 1,5420 & ns & 0,1328 & 0,1256 & 1,1189 & ns \\
\hline 5 & Renda & $-0,0878$ & 0,0422 & 4,3216 & * & $-0,0912$ & 0,0361 & 6,3698 & * \\
\hline \multirow[t]{6}{*}{6} & Origem & $-0,2793$ & 0,5008 & 0,3110 & ns & $-0,1176$ & 0,4207 & 0,0782 & ns \\
\hline & $-2 \ln \lambda$ & & & $178,27^{\star \star}$ & & & & 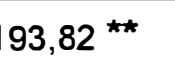 & \\
\hline & Pseudo- $R^{2}$ & & & 0,73 & & & & 0,10 & \\
\hline & Previsões cor & etas & & 0,78 & & & & 0,61 & \\
\hline & $\pi^{s}\{p \geq 0\}$ & & & 0,74 & & & & 0,77 & \\
\hline & $\bar{p}$ (R\$ /mês) ${ }^{2}$ & & & 3,04 & & & & 2,06 & \\
\hline
\end{tabular}

Obs.: ${ }^{\star}$ significativo a $1 \%$; * significativo a $5 \%$; ns: não significativo a $10 \%$;

Fonte: dados da pesquisa.

\footnotetext{
${ }^{21}$ Disponivel sob pedido no endereço eletrônico brugnaro@cca.ufscar.br.

${ }^{22}$ Calculado conforme eq.( 43 ).
} 
Com base na Tabela 13, para o modelo com limite simples, são significativos a $1 \%$ a constante e os coeficientes das variáveis preço e idade e, a $5 \%$, da variável renda. Os demais (sexo, escolaridade e origem da renda) não são significativos a $10 \%$. No modelo com limite duplo, repete-se a significância dos parâmetros, isto é, das variáveis explicativas incluídas no modelo, resultaram significativas a $1 \%$, além da constante, as estimativas dos parâmetros do valor proposto e da idade e, a $5 \%$, da renda. Os demais não são significativos a $10 \%$. O teste aplicado baseia-se nos valores críticos da distribuição $t$. Pelo critério de razão de verossimilhança $(-2 \ln \lambda)$, rejeita-se a hipótese nula para os coeficientes do modelo, ao nível de $1 \%$, tanto para o modelo com limite simples como para o modelo com limite duplo. A proporção de previsões corretas foi de cerca de 0,78 para o modelo com limite simples e de 0,61 para o modelo com limite duplo.

$\mathrm{Na}$ Tabela 13, as estimativas permitem: (i) comprovar que o modelo com limite duplo resulta em menor valor da disposição média a pagar; (ii) verificar a constatação de Hanemann et al. (1991), de que as estimativas obtidas no modelo de limite duplo são mais eficientes, isto é, têm variâncias menores que as obtidas por limite simples, e (iii) comparar as proporções de acerto dos dois modelos, notando-se que o modelo com limite simples tem um melhor poder de previsão do que o modelo com limite duplo.

Sob as restrições anotadas quando da apresentação da eq.( 49 ), pelos dados da Tabela 13, sempre mantendo-se as demais condições constantes, verifica-se que $\beta_{1}$ (preço a pagar) resultou no esperado sinal positivo, indicando que, à medida que o preço proposto aumenta, diminui a probabilidade de resposta afirmativa. A estimativa de $\beta_{5}$ (renda mensal per capita) tem sinal negativo, coerente com o esperado, isto é, a probabilidade de aceitação de determinado valor, coeteris paribus, cresce com a renda. $O$ sinal positivo de $\beta_{3}$ (idade) indica que individuos com mais idade, dado um determinado valor, têm menor probabilidade de concordar do que indivíduos 
mais jovens. Essa constatação é diferente da observada por Mitchell \& Carson (1989), que identificaram potenciais outliers (em pesquisas como esta, pessoas que declaram valores incoerentemente altos de disposição a pagar) entre indivíduos com baixo grau de instrução, mulheres e pessoas mais velhas. De maneira algo surpreendente, o sinal de $\beta_{4}$ (escolaridade) é positivo, indicando que a probabilidade de resposta afirmativa decresce com o aumento do grau de instrução. No entanto, o sinal se inverte quando observações com caracteristica de protesto são excluídos da amostra, como se verá na seção 4.3. Lembrar, todavia, que a estimativa de $\beta_{4}$ não é significativamente diferente de zero a $10 \%$, dando indicações de que o nível de escolaridade não afeta a probabilidade de resposta afirmativa. A estimativa de $\beta_{2}$ (sexo), não significativa a $10 \%$, tem sinal negativo, indicando tendência a maior probabilidade de as mulheres, em relação aos homens, responderem afirmativamente a um determinado valor. A estimativa do coeficiente da variável "origem da renda" $\left(\beta_{6}\right)$, não significativo a $10 \%$, foi aparentemente prejudicada pelo pequeno número de ocorrências de entrevistados que declararam ser a agricultura a principal fonte da renda familiar. Neste caso, também há inversão de sinal quando se excluem manifestações de protesto (ver Tabela 16).

Tendo à mão os valores estimados dos parâmetros e as médias amostrais $\bar{x}_{2}$ a $\bar{x}_{6}$, a estimativa da disposição média a pagar $(\bar{p})$ resultou em $R \$ 3,04 /$ mês para limite simples e $R \$ 2,06 /$ mês para limite duplo. Lembrar que esses valores correspondem a uma probabilidade de $50 \%$ de aceitação do preço proposto.

A probabilidade de aceitação de um preço não negativo, isto é, $\pi^{s}\{p \geq 0\}$, foi estimada em $74 \%$ para o modelo com limite simples, sendo que, a partir de $\mathrm{R} \$ 16,13$ mês, a probabilidade de aceitação é de $1 \%$ ou menos. Para o modelo com limite duplo, se admitida a utilização dos coeficientes estimados na formulação do modelo com limite simples, ter-se-ia $\pi^{s}\{p \geq 0\}=0,77$ e de $1 \%$ ou menos a partir de $\mathrm{R} \$ 9,95 /$ mês. 
Estimando-se os modelos com a variável $x_{5 a}=\ln \left(x_{5}\right)$, isto é, com o logaritmo da renda, observou-se, além da óbvia alteração das estimativas dos parâmetros, que: (i) para o modelo com limite simples não há alteração na significância dos parâmetros (nos níveis testados), na proporção de previsões corretas e no preço médio; (ii) para o modelo com limite duplo, dos indicadores citados no item anterior, apenas alterou-se o parâmetro da renda (tomada pelo seu logaritmo), que passou a ser significativo a $1 \%$, contra $5 \%$ no modelo original.

\subsection{Resultados com exclusão dos protestos}

\subsubsection{Perfil da amostra}

Atendendo recomendação encontrada na literatura, fizeram-se estimativas análogas às da seção anterior expurgando-se da amostra as observações em que se identificaram manifestações de protesto, considerados nesta categoria os casos em que os entrevistados declararam, para sua recusa em pagar qualquer dos dois preços propostos, um dos motivos relacionados de 2 a 4 na Tabela 12. Desse procedimento resultou a exclusão de 183 questionários (19,7\%), restando uma amostra de 747 observações. O perfil da amostra (sexo, idade e renda) está resumido na Tabela 14, e a resultante estrutura de respostas às propostas de pagamento está na Tabela 15.

Tabela 14. Amostra (em \%): sexo, idade e renda, excluídos os protestos.

\begin{tabular}{|c|c|c|c|c|c|c|c|c|c|c|}
\hline & \multirow{2}{*}{$\begin{array}{c}\text { Sexo } \\
\text { Fem }\end{array}$} & \multicolumn{4}{|c|}{ Idade (anos) } & \multicolumn{5}{|c|}{ Renda mensal per capita (SM) } \\
\hline & & $20-24$ & $25-39$ & $40-59$ & $60+$ & $<1$ & $1-2$ & $2-5$ & $5-10$ & $>10$ \\
\hline Amostra & 50,1 & 8,0 & 38,3 & 38,6 & 15,9 & 19,1 & 41,5 & 30,1 & 7,2 & 2,1 \\
\hline População & 50,5 & 14,1 & 39,0 & 31,3 & 15,6 & nd & nd & nd & nd & nd \\
\hline
\end{tabular}

SM: salário mínimo mensal (R\$ 136,00); nd: não disponível.

Fonte: dados da pesquisa, Tabela 4 e Tabela 6. 
98.

Como era óbvio de se esperar, por construção, a percentagem de entrevistados que declararam dispor-se a pagar um dos dois preços propostos aumentou (de $48 \%$ para $52 \%$ ) na amostra remanescente. Ainda assim, chama a atenção a ocorrência de $6,9 \%$ de respostas "não-não" à faixa de valores propostos mais baixos (ver Tabela 15).

Tabela 15. Respostas aos preços propostos, excluidos os protestos.

\begin{tabular}{|c|c|c|c|c|c|c|c|c|c|}
\hline \multicolumn{3}{|c|}{ Valores (R\$ /mês) } & \multirow[t]{2}{*}{ Amostra } & \multicolumn{2}{|c|}{$1^{\mathrm{a}}$ resposta } & \multicolumn{4}{|c|}{ Respostas combinadas } \\
\hline Inicial & Maior & Menor & & $S$ & $\mathbf{N}$ & SS & SN & NS & NN \\
\hline 0,50 & 1,00 & 0,10 & 175 & 152 & 23 & 73 & 79 & 11 & 12 \\
\hline 2,00 & 3,00 & 1,00 & 159 & 100 & 59 & 24 & 76 & 29 & 30 \\
\hline 5,00 & 7,00 & 3,00 & 133 & 47 & 86 & 8 & 39 & 21 & 65 \\
\hline 10,00 & 15,00 & 7,00 & 144 & 25 & 119 & 0 & 25 & 4 & 115 \\
\hline 30,00 & 50,00 & 15,00 & 136 & 0 & 136 & 0 & 0 & 1 & 135 \\
\hline & Totais & & 747 & 324 & 423 & 105 & 219 & 66 & 357 \\
\hline
\end{tabular}

S: sim; N: não.

Fonte: dados da pesquisa.

\subsubsection{Estimativas do modelo}

O processamento dos dados da amostra sem as manifestações de protesto resultou nas estimativas apresentadas na Tabela 16. Nessa tabela, verifica-se que, para o modelo com limite duplo, repete-se a significância dos coeficientes encontrada para a amostra total, nos mesmos níveis (considerando-se $1 \%, 5 \%$ e 10\%). Para evitar uma monótona repetição, omitem-se comentários análogos aos apresentados para o caso da amostra sem exclusão dos protestos, ressaltando-se, no entanto, que a hipótese nula é rejeitada no caso da significância da regressão (lembrando que $\hat{\beta}_{1}$ foi incluído no modelo restrito para o cálculo da razão de verossimilhança).

No caso da amostra expurgada das manifestações de protesto, coerentemente, é maior a estimativa da disposição a pagar, com média de $\mathrm{R} \$ 4,32 /$ mês (limite simples) e $R \$ 2,62$ ao mês (limite duplo), em valores 
correntes (dezembro de 1999). A probabilidade de aceitação de um preço não negativo foi estimada em $82 \%$ (limite simples) e $84 \%$ (limite duplo), isto é, mesmo excluindo-se os protestos, permanece uma probabilidade de pelo menos $16 \%$ de não se aceitar o pagamento de qualquer preço pelo aumento dos serviços ambientais em análise.

Tabela 16. Estimativas do modelo logito excluídos os protestos.

\begin{tabular}{|c|c|c|c|c|c|c|c|c|c|}
\hline \multirow[b]{2}{*}{$j$} & \multirow[b]{2}{*}{ Variável } & \multicolumn{4}{|c|}{ Limite simples } & \multicolumn{4}{|c|}{ Limite duplo } \\
\hline & & $\hat{\beta}_{j}$ & $\hat{\sigma}_{j}$ & Wald $\chi^{2}$ & & $\hat{\beta}_{j}$ & $\hat{\sigma}_{j}$ & Wald $\chi^{2}$ & \\
\hline 0 & Constante & $-2,2520$ & 0,4786 & 22,1387 & $\star \star$ & $-2,0722$ & 0,3950 & 27,5289 & $\star \star$ \\
\hline 1 & Valor & 0,3556 & 0,0312 & 129,9600 & $\star \star$ & 0,6183 & 0,0309 & 401,1914 & $\star \star$ \\
\hline 2 & Sexo & $-0,0154$ & 0,1956 & 0,0062 & ns & $-0,1787$ & 0,1642 & 1,1849 & ns \\
\hline 3 & Idade & 0,0239 & 0,0073 & 10,5787 & t* & 0,0198 & 0,0061 & 10,6168 & $\star \star$ \\
\hline 4 & Escolaridade & $-0,0295$ & 0,1577 & 0,0350 & ns & $-0,0416$ & 0,1370 & 0,0922 & ns \\
\hline 5 & Renda & $-0,1040$ & 0,0487 & 4,5667 & * & $-0,1025$ & 0,0401 & 6,5231 & * \\
\hline \multirow[t]{6}{*}{6} & Origem & 0,1871 & 0,5099 & 0,1345 & ns & 0,2504 & 0,4285 & 0,3416 & ns \\
\hline & $-2 \ln \lambda$ & & & $404,92 \star \star$ & & & & $56,30 \star \star$ & \\
\hline & Pseudo- $R^{2}$ & & & 0,68 & & & & 0,03 & \\
\hline & Previsões corr & tas & & 0,79 & & & & 0,56 & \\
\hline & $\pi^{s}\{p \geq 0\}$ & & & 0,82 & & & & 0,84 & \\
\hline & $\bar{\rho}$ (R\$ /mês) & & & 4,32 & & & & 2,63 & \\
\hline
\end{tabular}

Obs.: ${ }^{\star \star}$ significativo a $1 \%$; * significativo a $5 \%$; ns: não significativo a $10 \%$.

Fonte: dados da pesquisa.

Estimando-se o modelo com o logaritmo da renda, o coeficiente desta variável é significativo a $1 \%$, contra $5 \%$ no modelo sem transformação logarítmica, tanto para limite simples como para limite duplo. Além disso, há um pequeno acréscimo (menos de $1 \%$ ) na proporção de previsões corretas e ligeira variação no preço esperado ( $R$ \$ 0,01/mês a menos). 
Da análise da Tabela 13 e da Tabela 16 verifica-se que os modelos com limite simples apresentam maiores preços médios, mas, ao mesmo tempo, maiores proporções de acerto nas probabilidades estimadas.

Tomando-se o menor preço médio encontrado ( $R \$ 2,06 /$ mês, do modelo com limite duplo sem exclusão de protestos) e extrapolando-se este valor para a população da área de estudo (133 138 domicílios, Tabela 5), resulta num total próximo de $\mathrm{R} \$ 274$ mil mensais, em valores correntes. Embora seja temerário considerar-se a média calculada aplicável a cada uma das cidades envolvidas, e apenas a título de ilustração, para o município de Piracicaba o valor estimado seria de $R \$ 168$ mil mensais. A agência local de água e esgoto mantém um convênio de repasse de $\mathrm{R} \$ 0,01$ por metro cúbico de água consumida a órgãos que desenvolvem projetos de pesquisa e fomento sobre reposição de matas ciliares na área objeto desta pesquisa. Em dezembro de 1999, a autarquia em questão repassou ao Consórcio das Bacias dos Rios Piracicaba, Capivari e Jundiaí a importância de $R \$ 19613,63$, referentes à arrecadação do mês de outubro do mesmo ano, segundo o Jornal de Piracicaba (1999). Reforce-se a precariedade dessa comparação, visto que a pesquisa que sustenta este trabalho procurou captar o valor atribuido pela população às matas ciliares de toda a bacia hidrográfica. Assim, dada a disparidade populacional dos sete municípios que a compõem, fatalmente haveria a necessidade de recursos captados nos maiores centros migrarem para municípios com populações menores.

Tomando-se o maior preço médio estimado ( $R \$ 4,32 /$ mês, do modelo com limite simples, excluídos os protestos), o valor total estimado resulta em $\mathrm{R} \$ 575$ mil por mês, a preços correntes.

No próximo capitulo, apresentam-se um resumo e as principais conclusões deste trabalho, e algumas sugestões de linhas de pesquisa correlatas que eventualmente poderão despertar o interesse de pesquisadores ligados ao assunto. 


\section{RESUMO, CONCLUSÕES E SUGESTÕES}

Este trabalho teve por objetivo central estimar o valor atribuido pela população às matas ciliares da bacia do rio Corumbataí, SP. Utilizou-se um método de valoração contingente, com entrevistas a uma amostra da população residente nos municípios que contêm a área de estudo (Analândia, Charqueada, Corumbataí, Ipeúna, Piracicaba, Rio Claro e Santa Gertrudes).

Embora soe repetitivo, apresenta-se a seguir um resumo dos capítulos deste trabalho. A problemática de matas ciliares foi abordada considerando-se três aspectos: ambiental, legal e econômico. Do ponto de vista ambiental, as matas ciliares têm papel importante na proteção de mananciais, por representar uma barreira física e biológica ao fluxo de resíduos orgânicos e químicos que fluem das partes mais altas para os corpos d'água, tendo como vetor principal a água de chuva que excede a capacidade de absorção dos solos a montante e os fluxos hídricos sob a superfície do solo. A depuração da água tem efeitos benéficos sobre sua qualidade para consumo (humano, animal, industrial, agrícola e geração de energia) e sobre o habitat da vida aquática. Além disso, as matas ciliares servem como habitat de espécies vegetais diversificadas, como refúgio e fonte de alimentos de espécies animais e prestam outros serviços científicos, culturais e estéticos.

Apenas a presença de matas ciliares não resolve o problema dos resíduos carreados pela água de chuva. Sob os conceitos de tratamento a ser dispensado a bacias hidrográficas, a vegetação ripária é parte importante de um desenho mais amplo de conservação, que inclui, entre outros, controle da 
água de chuva captada pelas estradas e práticas agrícolas e mecânicas de manejo do solo.

Do ponto de vista legal, o chamado Código Florestal e suas alterações subseqüentes obrigam as propriedades agrícolas a manter (e a repor, onde for o caso) pelo menos $20 \%$ de sua área com vegetação permanente $^{23}$ e faixas mínimas de 30 a 500 metros às margens dos corpos d'água, dependendo da largura destes. Esta determinação de uma largura fixa é diferente de recomendações baseadas em conclusões científicas, que preconizam largura variável de acordo com características da bacia hidrográfica, ou melhor, de acordo com características das unidades de escoamento de água, como topografia e tipos de solo.

Em que pese seu papel na qualidade ambiental e a vigência, há muitos anos, de legislação restritiva, a área com vegetação nativa vem decrescendo ao longo do tempo e está muito aquém do determinado em lei. $A$ principal motivação para o desflorestamento tem sido de natureza econômica. A não aplicação generalizada da lei aparenta ser devida a dificuldades operacionais e aos custos de transação envolvidos com a identificação dos casos, notificação dos infratores, julgamento e aplicação das sanções. Isto se não houver também a interferência de interesses econômicos e políticos.

Como terceiro componente do problema, um eventual projeto de reposição de matas ciliares, além dos custos óbvios de plantio e condução, implica também em forçar as empresas agrícolas a dispor de menor quantidade do fator terra, alterando suas referências de eficiência econômica. A conseqüência mais visivel é a renúncia a receitas atualmente obtidas nas áreas em questão. Essa perda de receitas dificilmente poderá ser compensada financeiramente pelos serviços providos pelas matas ciliares, isto porque, como para a maioria dos serviços ambientais, não há o mecanismo de formação de

\footnotetext{
${ }^{23}$ Limite mínimo para a regiẫo em que está o estado de São Paulo.
} 
preços usual para bens de mercado. A maioria dos serviços ambientais são externalidades, não divisíveis, de consumo não excludente e com difícil identificação de substitutos. Por estes motivos, os critérios tradicionais da análise de benefícios e de custos ficam comprometidos, levando a uma avaliação distorcida de sua real magnitude. Além disso, na eventualidade de mecanismos de mercado associados a serviços ambientais, o preço captado é, perdoe-se a redundância, o valor sinalizado pelo mercado. Não se captam os valores de "não-uso", componentes usualmente admitidos do valor total de um bem (como o valor de existência, por exemplo). Para contornar o problema, desenvolveram-se métodos alternativos de se estimar 0 preço de bens ambientais, tendo-se tratado neste trabalho dos modelos que partem do princípio de maximização da utilidade individual.

Sob a teoria neoclássica, a utilidade individual é resultante do consumo de um conjunto de bens e serviços, em proporções estabelecidas pela preferência do consumidor e em quantidades limitadas pela renda disponivel. Assim, está-se pressupondo que há um ponto de equilíbrio do consumidor, em que este maximiza sua utilidade sujeito à sua restrição orçamentária. Na presença de um choque como, por exemplo, o aumento de um preço, há uma perturbação do equilíbrio e o consumidor aciona mecanismos internos de comportamento em busca de um novo equilíbrio, evento que pode durar mais ou menos tempo dependendo da habilidade da pessoa em tratar o problema de maximização, da intensidade do choque e de outros fatores. A perturbação do equilíbrio não ocorre obrigatoriamente por mudança nos preços, podendo ser causada por alteração no nível de suprimento de determinado serviço, sem necessariamente afetar preços e renda.

Nesse contexto, encaixam-se dois conceitos fundamentais da teoria da demanda compensada que podem, grosso modo, ser definidos como segue. $\mathrm{Na}$ iminência de, por exemplo, um aumento no suprimento de determinado 
serviço, o que deslocaria para cima seu nivel de utilidade, o indivíduo pode dispor-se a abrir mão de parte de sua renda para aumentar seu nível de consumo, mas mantendo inalterado seu nivel atual de utilidade (sentindo-se tão bem quanto antes da alteração). Neste caso, pressupõe-se que o indivíduo converte seu excedente compensatório da renda em disposição a pagar $(p)$ pelo aumento no consumo do serviço. Para manter seu nível de consumo mais baixo, mas alcançando o nível vislumbrado de utilidade mais alto, o indivíduo expressa seu excedente equivalente da renda através de sua disposição a aceitar compensação (a) pela renúncia do consumo suplementar. No caso de aumento do preço, ou de redução no suprimento do serviço, o raciocínio é análogo, em sentido inverso.

Se o bem (ou o serviço por ele prestado) é perfeitamente divisível, negociado em mercado concorrencial sem custos de transação e com pelo menos um substituto perfeito, então $a=p=m$, onde $m$ é o excedente do consumidor da teoria marshalliana (demanda ordinária). Por outro lado, se, por um motivo qualquer, o indivíduo não é capaz ou não dispõe de todos os elementos necessários para resolver o problema de maximização implícito, então $a>m>p$. Lembre-se que $m$ é formalmente observável, deduzido da função de demanda ordinária, ao passo que a e p, por definição, não são diretamente observáveis. Os valores do excedente compensatório e do excedente equivalente, medidos, no caso de um aumento do suprimento de um serviço, pelas respectivas disposição a pagar e a aceitar compensação, são considerados como estimativas teoricamente corretas do impacto no bem-estar. Assim, no caso específico de um projeto que aumente a disponibilidade de um serviço ambiental, a disposição a pagar da população beneficiada é tomada como uma medida indireta dos benefícios sociais do projeto, avaliada pelo seu nivel inferior (em outras palavras, sob uma perspectiva conservadora).

Para bens de mercado, o mecanismo de formação do preço sinaliza o valor que lhes é atribuiido. Por outro lado, no caso de bens ambientais, é 
freqüente não existir mercado em que sejam transacionados, impedindo a revelação da preferência dos consumidores. Neste caso, a estimativa do preço só é possivel por meios alternativos, que podem ser agrupados em três categorias principais. Uma delas baseia-se nas relações físico-químicas do ambiente (do tipo dose-resposta ou função dano) para atribuição de valores, mas tomando como referência preços de mercado (exemplos: nitrogênio, energia). Exige a identificação e o estabelecimento das formas funcionais das relações ambientais, o que só pode ser atendido em parte com o conhecimento atualmente disponivel.

O conceito de complementaridade fraca dá margem a um segundo grupo de métodos de avaliação, que exigem a determinação da demanda de um bem de mercado complementar a um serviço ambiental. Neste grupo estão o preço diferenciado de propriedades, os gastos com medidas preventivas ou corretivas e o custo de viagem. Esses métodos captam o preço do bem relacionado a atividades de mercado, ou seja, o valor de uso (às vezes, o valor de opção), mas não têm capacidade para captar os valores de "não-uso", como o valor de existência.

Um terceiro grupo de métodos, por valoração contingente, é o único reconhecidamente com potencial de captar o valor total (uso, opção e existência), pelo menos em nível individual. $O$ valor agregado de um bem, recurso ou serviço poderá jamais ser conhecido. O método típico consiste em construir um mercado hipotético e perguntar diretamente aos potenciais usuários o valor que atribuem ao bem proposto na transação. As questões podem ser abertas (isto é, a pessoa consultada declara o preço que julga adequado sem o estímulo de uma referência prévia) ou fechadas. Neste segundo caso, as técnicas mais comumente usadas são: (i) lances iterativos ("jogos de leilão"): proposta de um valor inicial, que pode ser aleatório ao longo da amostra, com ajustes posteriores sucessivos, para cima ou para baixo, conforme a primeira resposta tenha sido afirmativa ou negativa, 
respectivamente; (ii) cartela de pagamento: instrumento com uma escala de preços impressos, de zero até um valor $\$ \rho$ (que pode ser variável ao longo da amostra), apresentada ao participante da pesquisa para que este aponte 0 preço que julga adequado, e (iii) opçāo dicotômica ("sim" ou "não") a um dado preço, com uma variação representada pelo modelo com follow up (opção dicotômica com limite duplo), considerada estatisticamente mais eficiente; neste segundo caso, se a pessoa concorda com o peço inicial $\rho^{0}$, propõe-seIhe em seguida um preço $p^{a}$ mais alto, com expectativa de resposta "sim" ou "não" e, se a primeira resposta é negativa, propõe-se ao entrevistado um preço $p^{b}$, mais baixo; desta forma, estabelecem-se quatro intervalos em que pode estar o verdadeiro valor, não observável, atribuído pela pessoa ao serviço ambiental em análise.

Os métodos de valoração contingente são alvo de diversas críticas, principalmente quanto à precisão das estimativas. As principais fontes de distorção apontadas na literatura são: (i) viés estratégico, pelo risco de o indivíduo camuflar o verdadeiro valor que atribui ao serviço ambiental, declarando-o mais alto (se percebe que não terá de pagar realmente o preço declarado e tem interesse no aumento no suprimento do serviço) ou mais baixo (se acredita que sua resposta influirá no nivel de taxação) do que o valor que realmente atribui ao serviço ambiental em análise; (ii) viés de conhecimento e informação: passivel de se introduzir se o indivíduo decide sobre a transação proposta sem ter todas as informações necessárias que the permitam agir no sentido de maximizar sua utilidade; (iii) viés do veículo de pagamento: representado pela incerteza sobre o grau de confiança que as pessoas depositam, por exemplo, em governantes e agências oficiais, se estes estão envolvidos no processo, ou pela percepção que os indivíduos têm da responsabilidade pelas causas do problema (própria, de terceiros); (iv) outros, como tempo disponivel para decidir sobre a transação, recorrência à restrição 
orçamentária e disparidade entre os preços propostos e o "verdadeiro valor" atribuido pelo indivíduo.

Em que pesem essas restrições, que devem ser evitadas ou reduzidas no delineamento da pesquisa, os métodos de valoração contingente são amplamente utilizados em alguns paises, inclusive seus resultados sendo oficialmente levados em conta no julgamento de litígios sobre danos ambientais, como nos EUA (pela Corte de Apelação, por exemplo, desde 1989): A medida mais apropriada é a disposição a pagar, quando a estimativa dos benefícios sociais visa se fazer sob uma perspectiva conservadora dos valores.

As principais técnicas de levantamento dos dados são a remessa e o retorno dos questionários pelo correio, as entrevistas por telefone e as entrevistas face a face, estas podendo ser no endereço do entrevistado ou em pontos de fluxo de pessoas. Neste trabalho, utilizou-se esta última modalidade, e a medida visada foi a disposição a pagar pelo aumento no suprimento dos serviços ambientais prestados pelas matas ciliares, tendo-se utilizado questões fechadas ("sim" ou "não" a um dado preço), com réplica à primeira resposta.

$O$ tratamento econométrico do problema tem diversas formulações teóricas encontradas na literatura, mas duas são as mais citadas e aceitas. Uma pressupõe que o verdadeiro valor da disposição a pagar é uma variável aleatória, não observável diretamente, mas apenas através de indices obtidos por escolha dicotômica. Este modelo, então, deriva uma função valoração e é chamado por alguns autores de modelo de Cameron. Trata-se de um contraponto ao chamado modelo de Hanemann, que pressupõe que a função utilidade, de domínio intimo de cada indivíduo, é que tem um componente aleatório. O modelo de Hanemann parte do princípio de que cada indivídıo só concorda em pagar o preço proposto se sua utilidade (medida pela função indireta) na nova situação for maior que na situação atual, trabalhando, portanto, com uma função diferença de utilidade. Este modelo foi parcialmente 
108.

contestado e parcialmente revisto pelo seu autor. $O$ ponto central da divergência é que o modelo inicialmente propunha probabilidade de $100 \%$ de aceitação do preço zero (integração dos valores truncada para que $p \geq 0$ ), isto é, nenhum indivíduo teria sua utilidade reduzida com a implementação do projeto, condição que o autor do modelo reconheceu não ser passível de generalização. Dada a incerteza quanto à redução de utilidade, neste trabalho optou-se por se estimar a média da disposição a pagar utilizando-se a definição da média de uma distribuição probabilística. As funções de distribuição mais utilizadas são a normal e a logística, que diferem pouco em seus resultados, diferenças essas mais perceptíveis nas caudas da distribuição. Neste trabalho, adotou-se a função logística.

A pesquisa de campo foi realizada no período de outubro a dezembro de 1999, por 11 entrevistadores selecionados entre os alunos de graduação em Engenharia Agronômica do Centro de Ciências Agrárias da Universidade Federal de São Carlos (UFSCar), campus de Araras. Os entrevistadores passaram por algumas etapas de capacitação. A primeira consistiu na discussão e interpretação do problema e do material preliminar produzido. Em seguida, esse material (informação e questionário) foi testado em condições de campo nos sete municípios que contêm a bacia do rio Corumbataí, através de 171 entrevistas. Da discussão dos problemas verificados resultou o material definitivo (Apêndice 3), utilizado em 991 entrevistas. Dessas, excluíram-se 61 (por preenchimento incompleto ou por pressuposto metodológico), resultando uma amostra com 930 observações. Num passo seguinte, excluíram-se outros 183 questionários em que se identificaram manifestações de protesto, trabalhando-se então com 747 observações. Desses procedimentos resultaram dois conjuntos de estimativas (Tabela 13 e Tabela 16).

Para as condições deste trabalho (variáveis qualitativas e não disponibilidade de observações repetidas), a literatura recomenda a utilização do método de maximização da verossimilhança e, como a função adotada foi a 
109.

logística, houve necessidade de se recorrer a procedimentos de estimação não linear, tendo-se optado pelo método de Newton-Raphson.

Para o primeiro caso (sem excluir as manifestações de protesto), do modelo com limite duplo resultaram significativas a $1 \%$, além da constante, as estimativas dos parâmetros das variáveis valor proposto e idade e, a $5 \%$, da variável renda mensal per capita. A hipótese de coeficientes nulos (exceto $\beta_{0} \mathrm{e}$ $\beta_{1}$ ) foi rejeitada a $1 \%$ pelo critério de razão de verossimilhança. Dos quatro modelos considerados, a menor disposição a pagar média foi calculada em $\mathrm{R} \$ 2,06 /$ mês (limite duplo, sem exclusão de protestos), que equivale a $\mathrm{R} \$ 274$ mil mensais, a preços correntes, se considerada toda a população. Calculado pelo maior preço médio esperado (limite simples, com exclusão dos protestos), o montante é de $\mathrm{R} \$ 575$ mil mensais.

As estimativas feitas considerando-se o logaritmo natural da renda mensal per capita resultaram em diferenças muito pequenas em relação aos modelos originais.

O mencionado número de respostas com manifestações de protesto (189) pode estar indicando a presença de distorção causada pelo veículo de pagamento proposto, representado por um adicional na conta de água das residências (administrada por agências oficiais) e repasse dos recursos às prefeituras. Esse tipo de manifestação dá uma indicação do grau de confiança da população nos poderes constituídos no tocante à condução do projeto. Em que pese este problema, na concepção da pesquisa não se vislumbrou um outro veículo de pagamento tão verossímil quanto o utilizado.

Fazendo-se exercícios com as estimativas dos parâmetros, verifica-se que, sem excluir os protestos, a probabilidade de aceitação de um valor tendendo a zero é de $77 \%$, isto é, há $23 \%$ de probabilidade de não se aceitar qualquer valor, por baixo que seja. Excluídos os protestos, a probabilidade de aceitação de um valor bastante baixo é de $84 \%$ e, obviamente, é de $16 \%$ a probabilidade de sua não aceitação. 
Da experiência vivenciada neste trabalho, permite-se sugerir a eventuais interessados no tema aqui desenvolvido alguns procedimentos e linhas de pesquisa subseqüentes, sem a preocupação de ordená-los seqüencialmente com a estrutura deste trabalho:

a) a técnica de levantamento por meio de entrevistas na rua mostrouse uma escolha razoável, mas há necessidade de adequação dos dias da semana e dos horários para sua realização, devendo-se dar preferência aos períodos em que as pessoas estão sob menor pressão de compromissos de trabalho e domésticos;

b) a descrição do bem sob avaliação e do mercado hipotético é uma etapa delicada do processo, exigindo cuidadosa capacitação dos entrevistadores (se a técnica a utilizar for a de entrevistas);

c) o monitoramento do trabalho de campo deve ser intenso, sob pena de se perderem irremediavelmente informações desejadas; nesta pesquisa, informações (de importância secundária) sobre o bairro de residência do interessado foram comprometidas de forma irrecuperável num único final de semana;

d) a incerteza inicial quanto à representatividade da amostra pode ser reduzida pela verificação contínua do material à medida que vai sendo produzido, principalmente em relação a variáveis mais visíveis, por certeza ou por intuição, como sexo e idade; quanto às demais variáveis, é confiar nos procedimentos aleatórios adotados, sendo necessário amostras "suficientemente grandes";

e) a média da disposição a pagar pode ser deturpada pela presença de outliers na amostra, sendo necessário deixar perfeitamente explícitos todos os procedimentos adotados, lembrando que as estimativas dever ser vistas com cautela ou, no extremo, consideradas válidas no contexto da amostra (Freeman, 1986). 
Linhas de pesquisa correlatas poderiam ser, além da óbvia verificação dos resultados aqui estimados, a avaliação dos custos sociais da implantação de um projeto dessa natureza; benefícios e custos de um projeto mais amplo de recuperação ambiental, incluindo as matas ciliares como um de seus componentes; avaliação de serviços específicos, como, por exemplo, qualidade da água, e outras.

Espera-se, com este trabalho, estar oferecendo contribuição a alguns grupos potenciais de usuários: (a) pesquisadores interessados no assunto, pela revisão bibliográfica (não exaustiva) utilizada, pela formulação teórica do modelo e pelos procedimentos adotados; (b) formuladores de políticas ambientais, pela avaliação do comportamento do público afetado frente à proposta de uma "nova taxa" e, em grau secundário e transitório, pelos valores estimados, e (c) segmentos não governamentais da sociedade, pela possibilidade de argumentação em eventuais pendências entre grupos conflitantes ou em projetos de recuperação ambiental.

Finalmente, alerte-se que, por melhor que se procure planejar a pesquisa e os procedimentos, sempre podem aparecer incidentes totalmente imprevisíveis, como o conteúdo do Apêncide 4 procura ilustrar. 


\section{REFERÊNCIAS BIBLIOGRÁFICAS}

ADAMOWICZ, W.L.; BHARDWAJ, V.; MACNAB, B. Experiments on the difference between willingness to pay and willingness to accept. Land Economics, v.69, n.4, p.416-427, Nov. 1993.

ADAMOWICZ, W.L.; FLETCHER, J.J.; GRAHAM-TOMASI, T. Functional form and the statistical properties of welfare measures. American Journal of Agricultural Economics, v.71, n.2, p.414-421, May 1989.

AHLHEIM, M. Contingent valuation and the budget constraint. Ecological Economics, v.27, n.3, p.205-211, Nov. 1998.

AJZEN, I.; BROWN, T.C.; ROSENTHAL, L.H. Information bias in contingent valuation: effects of personal relevance, quality of information and motivational orientation. Joumal of Environmental Economics and Management, v.30, n.1, p.43-57, Jan. 1996.

AKERLOF, G.A.; DICKENS, W.T. The economic consequences of cognitive dissonances. American Economic Review, v.72, n.3, p.307-319, June 1982.

ALBERINI, A. Testing willingness-to-pay models of discrete choice contingent valuation surveys data. Land Economics, v.71, n.1, p.83-95, Feb. 1995.

ALBERINI, A.; KANNINEN, B.; CARSON, R.T. Modeling response incentive effects in dichotomous choice contingent valuation data. Land Economics, v.73, n.3, p.309-324, Aug. 1997.

ATTFIELD, R. Existence value and intrinsic value. Ecological Economics, v.24, n.2-3, p.163-168, Feb. 1998. 
113.

AZEVEDO, C.M.A. A decisão de preservar: o caso da mata ripária do médio rio Jaguari-Mirim, SP. São Paulo, 1994. Dissertação (Mestrado) Universidade de São Paulo, Programa de Pós-graduação em Ciência Ambiental (2v. Anexos).

AZZONI, C.R.; ISAI, J.Y. Estimating the costs of environmental protection in Brazil. Ecological Economics, v.11, n.2, p.127-133, Nov. 1994.

BACHA, C.J.C. A legislação sobre as áreas de preservação permanente e as reservas florestais. Preços Agrícolas, v.8, n.85, p.4-9, nov. 1993.

BARBIER, E.B. Alternative approaches to economic environmental interactions. Ecological Economics, v.2, n.1, p.7-26, April 1990.

BARBOSA, L.M. (Coord.). Simpósio sobre Mata Ciliar. Campinas: Fundação Cargill, 1989. 335p.

BARFIELD, B.J. et al. Water quality impacts of natural filter strips in karst areas. Trans. ASAE, v.48, n.2, p.371-382, 1998. /Resumo em Water Resources Abs.: http://erl.sibi.usp.br/cgibin/webspirs.cmd/.

BARRETT, C.B. Markets, social norms, and government in the service of environmentally sustainable development. Logan: Utah State University, Mar. 1998. (Economic Research Institute Study Paper, ERI\#98-05).

BATIE, S.S.; SHABMAN, L. Valuing nonmarket goods: conceptual and empirical issues: discussion. American Journal of Agricultural Economics, v.61, n.5, p.931-932, Dec. 1979.

BELLUZZO JR., W. Valoração de bens públicos: o método de avaliação contingente. São Paulo, 1995. 151p. Dissertação (Mestrado) - Faculdade de Economia, Administração e Contabilidade, Universidade de São Paulo.

BELZER, R.B.; THEROUX, R.P. Criteria for evaluating results obtained from contingent valuation methods. In: CASWELL, J.A. (Ed.). Valuing food safety and nutriiton: a close look at performing contingent valuation. Boulder: Westview Press, 1995. p.341-362. /http://agecon.lib.umn.edu/ 
BERGSTROM, J.C. et al. Economic value of wetlands-based recreation. Ecological Economics, v.2, n.2, p.129-147, June 1990b.

BERGSTROM, J.C.; STOLL, J.R.; RANDALL, A. The impact of information on environmental commodity valuation. American Journal of Agricultural Economics, v.72, n.3, p.614-621, Aug. 1990a.

BISHOP, C.; ROMANO, D. (Ed.) Environmental resource valuation: applications of the contingent valuation method in Italy. Boston: Kluwer Academic Publishers, 1998, 286+xi p. /Resenha em Ecological Economics, v.28, n.2, p.315-317, Feb. 1999/.

BISHOP, R.C.; HEBERLEIN, T.A. Measuring values of extramarket goods: are indirect measures biased? American Journal of Agricultural Economics, v.61, n.5, p.926-930, Dec. 1979.

BISHOP, R.C.; WOODWARD, R.T. Valuation of environmental quality under certainty. In: BROMLEY, D.W. (Ed.). Handbook of environmental economics. Oxford: Blackwell, 1995. p.543-567.

BLAMEY, R.K. Contingent valuation and the activation of environmental norms. Ecological Economics, v.24, n.1, p.47-72, Jan.1998.

BLAMEY, R.K.; BENNETT, J.W.; MORRISON, M.D. Yea-saying in contingent valuation surveys. Land Economics, v.75, n.1, p.126-141. Feb. 1999.

BLOMQUIST, G.C.; WHITEHEAD, J.C. Resource quality information and validity of willingness to pay in contingent valuation. Resource and Energy Economics, v.20, n.2, p.179-196, June 1998.

BOHARA, A.K. et al. Effects of total cost and group-size information on willingness to pay responses: open ended vs. dichotomous choice. Journal of Environmental Economics and Management, v.35, n.2, p.142-163. Mar. 1998. 
115.

BOLAND, M.; FOX, J. (S.); MARK, D. Consumer willingness-to-pay for pork produced under an integrated meat safety system. WESTERN AGRICULTURAL ECONOMICS ASSOCIATION ANNUAL MEETING, 1999. (Selected Paper). /http://agecon.lib.umn.edu/.

BOWKER, J.M.; STOLL, J.R. Use of dichotomous choice nonmarket methods to value the whooping crane resource. American Journal of Agricultural Economics, v.70, n.2, p.372-381, May 1988.

BOYLE, K.J.; BISHOP, R.C. Welfare measurements using contingent valuation: a comparison of techniques. American Joumal of Agricultural Economics, v.70, n.1, p.20-28, Feb. 1988.

BOYLE, K.J.; BISHOP, R.C.; WELSH, M.P. Starting point bias in contingent valuation bidding games. Land Economics, v.61, n.2, p.188-194, May 1985.

BRASIL. Código Florestal. Lei n 4.771, de 15 de setembro de 1965.

BRASIL. Constituição. República Federativa do Brasil, 1988.

BRASIL. Lei $n^{0}$ 7.754, de 14 de abril de 1989.

BRASIL. Lei no 8.171, de 17 de janeiro de 1991.

BREN, L.J. The geometry of a constant buffer-loading design method for humid watersheds. Forest Ecology and Management, v.110, n.1-3, p.113-125. Oct. 1998.

BROMLEY, D.W. Property rights and natural resource damage assesments. Ecological Economics, v.14, n.2, p.129-135, Aug. 1995.

BROMLEY, D.W. The environmental implications of agriculture. Madison: University of Wisconsin, Oct. 1996. (Staff Paper Series, 401). /http:// agecon.lib.umn.edu/.

BROOKSHIRE, D.S.; RANDALL, Ȧ.; STOLL, J.R. Valuing increments and decrements in natural resource service flows. American Journal of Agricultural Economics, v.62, n.3, p.478-488, Aug. 1980. 
BROWN, T.C. et al. Which response format reveals the truth about donations to a public good? Land Economics, v.72, n.2, p.152-166, May 1996.

BROWN, T.C. Experiments on the difference between willingness to pay and willingness to accept: comments. Land Economics, v.70, n.4, p.520-522, Nov. 1994.

BROWN, T.C.; GREGORY, R. Why the WTA-WTP disparity matters. Ecological Economics, v.28, n.3, p.323-325, Mar. 1999.

BROWN, T.C.; PETERSON, G.L.; TONN, B.E. The values of jury to aid natural resource decision. Land Economics, v.71, n.2, p.250-260, May 1995.

BUTTURINI, A.; SABATER, F. Effects of riparian vegetation removal on fluxes of dissolved matter in a Mediterranen stream. In: Buffer zones: their processes and potential in water protection. Cardigan: Samara Publishing Limited, 1996. p.31. /Resumo em Water Resources Abs.: http://erl.sibi.usp.br/cgibin/webspirs.cmd/.

CAMERON, T.A.; JAMES, M.D. Efficient estimation methods for "closed-ended" contingent valuation surveys. Review of Economics and Statistics, v.69, n.2, p.269-276, May 1987.

CARPENTIER, A.; VERMERSCH, D. Willingness to pay for an increase in the quality of drinking water: an applciation to France. AMERICAN AGRICULTURAL ECONOMICS ASSOCIATION ANNUAL MEETING, 1999. (Presented Paper). /http://agecon.lib.umn.edu/.

CARSON, R.T. et al. Contingent valuation and revealed preference methodologies: comparing the estimates for quasi-public goods. Land Economics, v.72, n.1, p.80-99, Feb. 1996.

CARSON, R.T. et al. Temporal reliability of estimates from contingent valuation. Land Economics, v.73, n.2, p.151-163, May 1997.

CASER, D.V. et al. Evolução da cobertura florestal no Estado de São Paulo, 1970-95. Informações Econômicas, v.28, n.5, p.27-46, maio 1998. 
CASIMIRO FILHO, F. Valoração econômica de benefícios ambientais: o caso do turismo no litoral cearense. Piracicaba, 1995. 81p. Dissertação (Mestrado) - Escola Superior de Agricultura "Luiz de Queiroz", Universidade de São Paulo.

CHAMP, P.A. et al. Using donation mechanisms to value nonuse benefits from public goods. Journal of Environmental Economics and Management, v.33, n.2, p.151-162, Jan.1997.

CONSÓRICO recebe $01^{\circ}$ cheque do Semae. Jornal de Piracicaba, 17/1.2/1999, p.A-10.

CONSTANZA, R.; PERRINGS, C. A flexible assurance bonding system for improved environmental management. Ecological Economics, v.2, n.1, p.57-75, April 1990.

COOPER, J.; LOOMIS, J. Sensitivity of willingness-to-pay estimates to bid design in dichotomous choice contingent valuation models. Land Economics, v.68, n.2, p.211-224, May 1992.

CRESTANA, M.S.M. Recomposição artificial de mata ciliar. In: LOMBARDI NETO, F.; DRUGOWICH, M.I. (Coord.). Manual técnico de manejo e conservação do solo e água. Campinas: CATI, 1994. v.5, p.117-128. (Manual Técnico, 42).

CRUTCHFIELD, S.R.; FEATHER, P.M.; HELLERSTEIN, D.R. The benefits of protecting rural water quality: an empirical analysis. Washington: U.S. Department of Agriculture, Jan. 1995. (Agricultural Economic Report, 701). CUMMINGS, R.G.; BROOKSHIRE, D.S.; SCHULZE, W.D. Valuing environmental goods: an assessment of the contingent valuation method. New Jersey: Rowman \& Allanhead, 1986. 269p.

DALY, H.E. Toward some operational principles of sustainable development. Ecological Economics, v.2, n.1, p.1-6, April 1990. 
DUPONT, D. The effect of sequence on willingnes to pay. American Journal of Agricultural Economics, v.79, n.5, p.1732-1732, 1997. (Abstract).

ECHEVERRÍA, J.; HANRAHAN, M.; SOLÓRZANO, R. Valuation of non-priced amenities provided by the biological resources within the Monteverde Cloud Forest Preserve, Costa Rica. Ecological Economics, v.13, n.1, p.43-52, April 1995.

FENNESSY, M.S.; CRONK, J.K. The effectiveness and restoration potential of riparian ecotones for the management of nonpoint source pollution, particularly nitrate. Crit. Rev. Environ. Sci. Technol., v.27, n.4, p.285-317, 1997. /Resumo em Water Resources Abs.: http:/lerl.sibi.usp.br/cgibin/ webspirs.cmd/.

FLORES, N.E. Reconsidering the use of Hicks neutrality to recover total value. Journal of Environmental Economics and Management, v.31, n.1, p.4964, July 1996.

FLORES, N.E.; CARSON, R.T. The relationship between the income elasticities of demand and willingness to pay. Joumal of Environmental Economics and Management, v.33, n.3, p.287-295, July 1997.

FREEMAN, A.M. III. On assessing the state of arts of the contingent valuation method of valuing environmental changes. In: CUMMINGS, R.G.; BROOKSHIRE, D.S.; SCHULZE, W.D. Valuing environmental goods: an assessment of the contingent valuation method. New Jersey: Rowman \& Allanhead, 1986. p.148-161.

FREEMAN, A.M. III. Approaches to measuring public goods demands. American Journal of Agricultural Economics, v.61, n.5, p.915-920. Dec. 1979.

FUNDAÇÃO INSTITUTO BRASILEIRO DE GEOGRAFIA E ESTATISTICAIBGE. Contagem da população, 1996. Rio de Janeiro: IBGE, 1997. 
119.

FUNDAÇÃO SISTEMA ESTADUAL DE ANÁLISE DE DADOS-SEADE Informações dos Municípios Paulistas. /http://hww.seade.gov.br (13/08/1999)/.

FUNDAÇÃO SISTEMA ESTADUAL DE ANÁLISE DE DADOS-SEADE. Anuário Estatístico do Estado de São Paulo 1994. São Paulo: SEADE, 1995.

GITTINGER, J.P. Economic analysis of agricultural projects. Baltimore: Johns Hopkins University Press, 1972. 221p.

GONZÁLEZ-CABÁN, A.; LOOMIS, J. Economic benefits of maintaining ecological integrity of Río Mameyes, in Puerto Rico. Ecological Economics, v.21, n.1, p.63-75, April 1997.

GOWDY, J.; O'HARA, S. Economic theory for environmentalists. Debray Beach: St.Lucie Press, 1995. 192p.

GRASSO, M. et al. Aplicação de técnicas de avaliação econômica ao ecossistema manguezal. In: MAY, P.H. (Org.). Economia ecológica: aplicações no Brasil. Rio de Janeiro: Campus, 1995, p.49-81.

GREENE, W.H. Econometric analysis. 3.ed. New Jersey: Prentice-Hall, 1997. $1075 p$.

GREGORY, R. et al. How precise are monetary representation of environmental improvements? Land Economics, v.71, n.4, p.462-473, Nov. 1995.

GREGORY, R.; SLOVIC, P. A construtive approach to environmental valuation. Ecological Economics, v.21, n.3, p.175-181, June 1997.

GUTÉS, M.C. The concept of weak sustainability. Ecological Economics, v.17, n. 3, p.147-156, June 1996.

HANEMANN, W.; LOOMIS, J.; KANNINEN, B. Estimation efficiency of doublebounded dichotomous choice contingent valuation. American Journal of Agricultural Economics, v.73, n.4, p.1255-1263, Nov. 1991. 
120.

HANEMANN, W.M. Welfare evaluation in contingent valuation experiments with discrete responses. American Joumal of Agricultural Economics, v.66, n.3, p.332-341, Aug. 1984.

HANEMANN, W.M. Welfare evaluations in contingent valuation experiments with discrete response data: reply. American Joumal of Agricultural Economics, v.71, n.4, p.1057-1061, Nov. 1989.

HANEMANN, W.M. Willingness to pay and willingness to accept: how much can they differ? American Economic Review, v.81, n.3, p.635-647, June 1991. HARPMAN, D.A.; WELSH, M.P. Measuring goodness of fit for the doublebounded logit model: comment. American Joumal of Agricultural Economics, v.81, n.1, p.235-240, Feb. 1999.

HARRIS, C.C.; BROWN, G. Gain, loss and personal responsability: the role of motivation in resource valuation decision-making. Ecological Economics, v.5, n.1, p.73-92, Mar. 1992.

HARRISON, G.W.; LESLEY, J.C. Must contingent valuation cost so much? Joumal of Environmental Economics and Management, v.31, n.1, p.7995, July 1996.

HEFTING, M.M.; KLEIN, J.J.M. Nitrogen removal in buffer strips along a lowland stream in the Netherlands: a pilot study. Environmental Pollution, v.102, n.1, Supl.1, p.521-526, 1998.

HERRIGES, J.A. Measuring goodness of fit for the double-bounded logit model: comment. American Joumal of Agricultural Economics, v.81, n.1, p.231234, Feb. 1999.

HINTERBERGER, F.; LUCKS, F.; SCHMIDT-BLEEK, F. Material flows vs. 'natural capital': what makes an economy sustainable? Ecological Economics, v.23, n.1, p.1-14, Oct. 1997. 
HOEHN, J.P. Valuing the multidimensional impacts of environmental policy: theory and methods. American Journal of Agricultural Economics, v.73, n.2, p.289-299, May 1991.

HOEHN, J.P.; RANDALL, A. Too many proposals pass the benefit cost test. American Economic Review, v.79, n.3, p.544-551, June 1989.

HOEVENAGEL, R.; VAN DER LINDEN, J.W. Effects of different descriptions of the ecological good on willingness to pay values. Ecological Economics, v.7, n.3, p.223-238, June 1993.

HORWATH, W.R. et al. Denitrification potential of a natural grass riparian zone and adjacent perenial ryegrass seed production field. In: Buffer zones: their processes and potential in water protection. Cardigan: Samara Publishing Limited, 1996. p.44. /Resumo em Water Resources Abs.: http://erl.sibi.usp.br/cgibin/webspirs.cmd/.

HUBBARD, R.K.; LOWRANCE, R. Assessment of forest management effects on nitrate removal by riparian buffer systems. Trans. ASAE, v.40, n.2, p.383394, 1997. /Resumo em Water Resources Abs.: http://erl.sibi.usp.br/cgibin/ webspirs.cmd/.

HUBBARD, R.K.; LOWRANCE, R.R. Riparian forest buffer system research at the Coastal Plain Experiment Station, Tifton, GA. Water and air pollution, v.77, n.3-4, p.409-432, Oct. 1994. /Resumo em Web of Science: http:// unw.usp.br/sibi/.

HUETING, R. The use of the discount rate in a cost-benefit analysis for different uses of a humid tropical forest area. Ecological Economics, v.3, n.1, p.4357, Mar. 1991.

INFORMAÇÕES ECONÔMICAS. São Paulo: Instituto de Economia Agricola, v.26, n.2, p.103, fev. 1996. 
JOHANSSON, P.-O. The economic theory and mesaurement of environmental benefits. Cambridge: Cambridge University Press, 1987. $223 p$.

JOHANSSON, P.-O.; KRISTRÖM, B.; MÄLER, K.G. Welfare evaluations in contingent valuation experiments with discrete response data: comment. American Journal of Agricultural Economics, v.71, n.4, p.1054-1056, Nov. 1989.

JUDGE, G.C. et al. Introduction to the theory and practice of econometrics. 2.ed. New York: John Wiley \& Sons, 1988. 1024p.

KAGEYAMA, P.Y.; CASTRO, C.F.A.; CARPANEZZI, A.A. Implantação de matas ciliares: estratégias para auxiliar a sucessão de vegetação secundária. In: BARBOSA, L.M. (Coord.). Simpósio sobre mata ciliar. Campinas: Fundação Cargill, 1989. p.130-143.

KAHNEMAN, D.; TVERSKY, A. Prospect theory: an analysis of decisions under risk. Econometrica, v.47, n.2, p.263-291, Mar. 1979.

KANNINEN, B.J. Optimal experiment design for double-bounded dichotomous choice contingent valuation. Land Economics, v.69, n.2, p.138-146, May 1993.

KANNINEN, B.J.; KHAWAJA, M.S. Measuring goodness of fit for the doublebounded logit model. American Journal of Agricultural Economics, v.77, n.4, p.885-890, Nov. 1995.

KAZMIERCZAK JR., R.F.; HUGHES, D.W. Reasonable value and the role of negotiation in agriculture's use of the environment. Baton Rouge: Louisiana State University Agricultural Center, June 1996. (Staff Paper 9609). /http://agecon.lib.umn.edu/.

KOFFLER, N.F. Uso das terras do rio Corumbatai em 1990. Geografia, v.18, n.1, p.135-150, abril 1993. 
KRUTILA, J.V. Conservation reconsidered. American Economic Review, v.57, n.4, p.777-786, Sep. 1967.

LANCASTER, K,J. A new approach to consumer theory. Journal of Political Economy, v.74, n.2, p.132-157. April 1966.

LEME, E.J.A., MATSUOKA, S.; SOUZA, J.M.B. Recomposição e preservação das matas ciliares e proteção ambiental da bacia hidrográfica do Ribeirão das Araras. Araras: Associação de Proteção e Preservação Ambiental de Araras.

LIMA, W.P. Função hidrológica da mata ciliar. In: BARBOSA, L.M. (Coord.). Simpósio sobre mata ciliar. Campinas: Fundação Cargill, 1989. p.25-42.

LOMBARDI NETO, F.; DRUGOWICH, M.I. (Coord.). Manual técnico de manejo e conservação do solo e água. Campinas: CATI, 1994. $5 \mathrm{v}$. (Manual Técnico, 42).

LOOMIS, J. et al. Paired comparison estimates of willingness to accept versus contingent valuation estimates of willingness to pay. Journal of Economic Behavior \& Organization, v.35, n.4, p.501-515, May 1998.

LOOMIS, J.; EKSTRAND, E. Alternative approaches for incorporating respondent uncertainty when estimating willingness to pay: the case of the Mexican spotted owl. Ecological Economics, v.27, n.1, p.29-41, Oct. 1998.

LOOMIS, J.; GONZALEZ-CABÁN, A.; GREGORY, R. Do reminders of substitutes and budget constraints influence contingent valuation estimates? Land Economics, v.70, n.4, p.499-506, Nov. 1994.

LOOMIS, J.B.; GONZALEZ-CABÁN, A. A willingness to pay function for protecting acres of spotted owl habitat from fire. Ecological Economics, v.25, n.3, p.315-322, June 1998.

LOPES, I.V.; BASTOS FILHO, G.S.; BILLER, D.; BALE, M. (Org.) Gestão ambiental no Brasil: experiência e sucesso. Rio de Janeiro: Fundação Getúlio Vargas, 1996. 377p. 
124.

LÓPEZ, A.A.O. Análise dos custos privados e sociais da erosão do solo: o caso da bacia do rio Corumbataí. Piracicaba, 1997. 118p. Tese (Doutorado) Escola Superior de Agricultura "Luiz de Queiroz", Universidade de São Paulo.

LOWRANCE, R. et al. Herbicide transport in a managed riparian forest buffer system. Trans.-ASAE, v.40, n.4, p.1047-1057, 1997b. /Resumo em Water Resource Abs.: http://erl.sibi.usp.br/cgibin/webspirs.bat/.

LOWRANCE, R. et al. Water quality functions of riparian forest buffers in Chesapeake Bay watersheds. Environment Management, v.21, n.5, p.687712, 1997a. /Resumo em Water Resource Abs.: http://erl.sibi.usp.br/cgibin/ webspirs.bat.

LOWRANCE, R.R. The potential role of riparian forest ecosystems as buffer zones. In: Buffer zones: their processes and potential in water protection. Tresaith: Samara Publishing Limited, 1996. p.22-23. (Conference Handbook). /Resumo em Water Resource Abs.: http:/lerl.sibi.usp.br/cgibin/ webspirs. bat/.

MACHADO, P.A.L. Comentários sobre a reserva florestal legal. /http://uww.florestal.ipef.br/legislacao, 14/06/1999/.

MADDALA, G.S. Introduction to econometrics. New York: Macmillan Publishing Company, 1988. 472p.

MADDALA, G.S. Limited-dependent and qualitative variables in econometrics. Cambridge: Cambridge University Press, 1983. 401p.

MANDER, $U$. The potential role of wet meadows and grey alder forests as buffer zones. In: Buffer zones: their processes and potential in water protection. Cardigan: Samara Publishing Limited, 1996. p.24-25. /Resumo em Water Resources Abs.: http://erl.sibi.usp.br/cgibin/webspirs.cmd/. 
MANTOVANI, W. Conceituação e valores condicionantes. In: BARBOSA, L.M. (Coord.) Simpósio sobre mata ciliar. Campinas, 1988. Campinas: Fundação Cargill, 1989. p.11-19.

MARGARIDO, L.C.C. Valoração ambiental de alguns aspectos funcionais de uma área natural de conservação. Estudo de caso: Estação Ecológica de Jataí, Luiz Antonio, SP. São Carlos, 1994. 92p. Tese (Doutorado) Universidade Federal de São Carlos.

MARQUES, J.F. Efeito da erosão do solo na geração de energia elétrica: uma abordagem da economia ambiental. São Paulo, 1995. 257p. Tese (Doutorado) - Faculdade de Economia, Administração e Contabilidade, Universidade de São Paulo.

MARQUES, J.F.; COMUNE, A.E. A teoria neoclássica e a valoração ambiental. In: ROMEIRO, A.R.; REYDON, B.P.; LEONARDI, M.L.A. (Org.). Economia do meio ambiente: teoria, políticas e a gestão de espaços regionais. Campinas: Unicamp. Instituto de Economia, 1997. p.21-42.

MAXWELL, S. Valuation of rural environmental improvement using contingent valuation methodology: a case-study of the Marston-Vale-Forest-Project. Journal of Environmental Economics and Management, v.41, n.4, p.385-399. Aug. 1994. /Resumo em Web of Science: http://wos.isiglobalnet. com/brazil/CIW.cgi/.

MILLER, K.W. et al. The feasibility of a street-intercept survey in an AfricanAmerican community. American Joumal of Public Health, v.87, n.4, p.655-658, April 1997.

MITCHELL, R.C.; CARSON, R.T. Using surveys to value public goods: the contingent valuation method. Washington: Resources for the Future, 1989. $463 p$. 
126.

MORE, T.A; AVERILL, J.R.; STEVENS, T.H. Values and economics in environmental management: a perspective and critique. Journal of Environmental Management, v.48, n.4, p.397-409, Dec. 1996.

MUELLER, C.C. Gestão de matas ciliares. In: LOPES, I.V. et al. (Org.). Gestão ambiental no Brasil: experiência e sucesso. Rio de janeiro: Fundação Getúlio Vargas, 1996. p.185-214.

MULARKEY, D.J.; BISHOP, R.C. Sensitive to scope: evidence from a CVM study of wetlands. AMERICAN AGRICULTURAL ECONOMICS ASSOCIATION ANNUAL MEETING, 1999. (Presented Paper). /http:// agecon.lib.umn.edu/.

NASSIF, A.M.A.; VIANA, V.M. Melhoria do sistema de produção de água pelo SEMAE através de atividades de recuperação e conservação florestal. In: SEMINÁRIO DE RECUPERAÇÃO FLORESTAL E DESENVOLVIMENTO SUSTENTÁVEL NA BACIA DO RIO CORUMBATAí, 2. Piracicaba: SEDEMA, 1998. p.40-42.

NYBORG, K. Homo economicus and homo politicus: interpretation and aggregation of environmental values. Journal of Economic Behavior \& Organization, v.42, n.3, p.305-322, July 2000.

PATE, J.; LOOMIS, J. The effect of distance on willingness to pay values: a case study of wetlands and salmon in California. Ecological Economics, v.20, n.3, p.199-207. Mar. 1997.

PEARCE, D.W.; TURNER, R.K. Economics of natural resources and the environment. Baltimore: Johns Hopkins University Press, 1989. 377p.

PERMAN, R.; MA, Y.; MCGILVRAY, J. Natural resource \& environmental economics. Essex: Addison Wesley Longman Limited, 1996. 396p.

PINO, F.A. et al (Org.). Levantamento censitário de unidades de produção agrícola do Estado de São Paulo. São Paulo: IEA, CATI, SAA, 1997. 4v. 
127.

POPP, J.H.; HOAG, D. Sustainable resource management: a methodology for analysis. AMERICAN AGRICULTURAL ECONOMICS ASSOCIATION ANNUAL MEETING, 1998. (Selected Paper). /http://agecon.lib.umn.edu/.

POSAVAC, S.S. Strategic overbidding in contingent valuation: stated economic value of public goods varies according to consumers expectation of funding source. Journal of Economic Psychology, v.19, n.2, p.205-214, April 1998.

POZO, J. et al. Inputs of particulate organic matter to streams with different riparian vegetation. J.-N.-AM.-BENTHOL.-SOC., v.16, n.3, p.602-611, 1977. /Resumo em Water Resource Abs.: http://erl.sibi.usp.br/cgibin/ webspirs.bat/.

RANDALL, A. Resource economics: an economic approach to natural resource and environmental policy. 2 ed. New York: John Wiley \& Sons, 1987. 434p.

RANDALL, A. The NOAA panel report: a new begining or the end of an era? American Journal of Agricultural Economics, v.79, n.5, p.1489-1494, 1997.

RANDALL, A. The possibility of satisfactory benefit estimation with contingent markets. In: CUMMINGS, R.G.; BROOKSHIRE, D.S.; SCHULZE, W.D. Valuing environmental goods: an assessment of the contingent valuation method. New Jersey: Rowman \& Allanhead, 1986. p.114-122.

RANDALL, A. What practicing agricultural economists really need to know about methodology. American Journal of Agricultural Economics, v.75, Sp.Iss., p.48-59, Oct. 1993.

RANDALL, A.; HOEHN, J.P. Embedding in market demand systems. Journal of Environmental Economics and Management, v.30, n.3, p.369-380, May 1996. 
128.

RANDALL, A.; STOLL, J.R. Consumer's surplus in commodity space. American Economic Review, v.70, n.3, p.449-455, June 1980.

RAVENSWAAY, E.O.; WOHL, J. Using contingent valuation methods to value the health risks from pesticides residues when risks are ambiguous. In: CASWELL, J.A. (Ed.). Valuing food safety and nutrition: a closer look at performing contingent valuation, 14. Boulder: Westview Press, 1995. p.287317. /http://agecon.lib.umn.edu/.

REISER, B.; SHECHTER, M. Incorporating zero values in the economic valuation of environmental program benefits. Environmetrics, v.10, p.87101, 1999.

RIBAUDO, M.O. Targeting the conservation reserve program to maximize water quality benefits. Land Economics, v.65, n.4, p.320-332, Nov. 1989.

RIBAUDO, M.O.; HELLERSTEIN, D. Estimating water quality benefits: theoretical and methodological issues. Washington: U.S. Department of Agriculture, Sep. 1992. (Technical Bulletin, 1808). /http:/lagecon.lib.umn.edu/.

RIBEIRO, F.L. Avaliação contingente de danos ambientais: o caso do rio MeiaPonte em Goiânia-GO. Viçosa, 1998. 80p. Tese (Mestrado) - Universidade Federal de Viçosa.

ROSADO, M. Willingness to pay for drinking water in urban areas of developing countries. Salt Lake City: AMERICAN AGRICULTURAL ECONOMICS ASSOCIATION ANNUAL MEETING, 1998. /http://agecon.lib.umn.edu/.

SAGOFF, M. Aggregation and deliberation in valuing environmental public goods: a look beyond contingent valuation. Ecological Economics, v.24, n.2-3, p.213-230, Feb.Mar. 1998.

SAMUELSON, P.A. The pure theory of public expenditure. Review of Economics and Statistics, v.36, n.4, p.387-389, Nov. 1954. 
SÃO PAULO (Estado). Comitê das Bacias Hidrográficas dos Rios Piracicaba, Capivari e Jundiaí. Relatório da situação dos recursos hídricos 1994. São Paulo: DAEE, 1995. 89p.

SÃO PAULO (Estado). Conselho Estadual de Recursos Hídricos. Plano Estadual de Recursos Hídricos. São Paulo: Conselho Estadual de Recursos Hídricos, 1990. 137p.

SÃO PAULO (Estado). Secretaria de Recursos Hídricos, Saneamento e Obras. /http://mww.recursoshídricos.sp.gov.br (13/08/1999)/.

SÃO PAULO (Estado). Secretaria do Meio Ambiente. Bacia do rio Piracicaba: estabelecimento de metas ambientais e reenquadramento dos corpos d'água. São Paulo: Secrearia do Meio Ambiente, 1994. 81p. (Série Relatórios).

SCHULZE, P.C. Cost-benefit analysis and environmental policy. . Ecological Economics, v.9, n.3, p.197-199, April 1994.

SCHULZE, W.D.; D'ARGE, R.C.; BROOKSHIRE, D.S. Valuing environmental commodities: some recent experiments. Land Economics, v.57, n.2, p.149172, May 1981.

SERVIÇO MUNICIPAL DE ÁGUA E ESGOTO-SEMAE. /http://mww. semaepiracicaba.org.br (13/08/1999)/.

SHOGREN, J.F.; CROCKER, T.D. Adaptation and the option value of uncertain environmental resources. . Ecological Economics, v.2, n.3, p.301-310, Dec. 1990.

SIMPÓSIO NACIONAL DE RECUPERAÇÃO DE ÁREAS DEGRADADAS, 3, Ouro Preto, 1997, Sociedade Brasileira de Recuperação de Áreas Degradadas; Universidade Federa! de Viçosa, 1997.

SMITH, V.K. Nonmarket valuation of environment resources: an interpretive appraisal. Land Economics, v.69, n.1, p.1-26, Feb. 1993. 
SNYDER, N.J. et al. Impact of riparian forest buffers on agricultural nonpoit source pollution. Journal of American Water Resource Association, v.34, n.2, 1998. /Resumo em Water Resource Abs.: http://erl.sibi.usp.br/ cgibin/webspirs.bat/.

SÖDERBAUM, P. Actors, ideology, markets: neoclassical and institucional perspectives on environmental policy. Ecological Economics, v.10, n.1, p.47-60, May 1994.

SPOONER, J.F.; FLAHERTY, B. Comparison of 3 data-collection methodologies for the study of young ilicit drug users. Australian Journal of Public Health, v.17, n.3, p.195-202, Sep. 1993.

STEVENS, T.H.; DECOTEAU, N.E.; WILLIS, C.E. Sensitivity of contingent valuation to alternative payment schedules. Land Economics, v.73, n.1, p.140-148, Feb. 1997.

SUKHAROMANA, R.; SUPALLA, R.J. Effect of perception on willingness to pay for improved water quality. AMERICAN AGRICULTURAL ECONOMICS ASSOCIATION ANNUAL MEETING, 1998. (Selected Paper). /http:// agecon.lib.umn.edu/.

TOLEDO, P.E.N. Impacto ambiental e análise econômica de medidas mitigadoras: o caso da microbacia hidrográfica do córrego São Joaquim, Pirassununga (SP). Piracicaba, 1997. 142p. Tese (Doutorado) - Escola Superior de Agricultua Luiz de Queiroz, Universidade de São Paulo.

TOMER, J.F. The human firm in the natural environment: a socio-economic analysis of its behavior. Ecological Economics, v.6, n. 2, p.119-138, Oct.1992.

TROPPMAIR, H.; MACHADO, M.L.A. Variação da estrutura da mata de galeria na bacia do rio Corumbataí (SP) em relação à água do solo, do tipo de margem e do traçado do rio. Biogeografia, v.8, p.1-28, 1974. 
UUSI-KAEMPPAE, J. et al. The interactions of buffer zones and phosphorous runoff. In: HAYCOCK, N.E.; BURT, T.P.; GOULDING, K.W.T.; PINAY, G. (Ed.). Buffer zones: their processes and potential in water protection. Harpenden: Quest Environmental, 1997. p.43-53. IResumo em Water Resources Abs.: http://erl.sibi.usp.br/cgibin/webspirs.cmd/.

VAN DIJK, P.M.; KWAAD, F.J.P.M. Effects of grass strips on sediment load and hydraulics of shallow flow. In: Buffer zones: their processes and potential in water protection. Cardigan: Samara Publishing Limited, 1996. p.66. /Resumo em Water Resources Abs.: http://erl.sibi.usp.br/cgibin/ webspirs.cmd/.

VAN PELT, M.J.F. Ecologically sustainable development and project appraisal in developing countries. Ecological Economics, v.7, n.1, p.19-42, Feb. 1993.

VATN, A.; BROMLEY, D.W. Choices without prices without apologies. In: BROMLEY, D.W. (Ed.). Handbook of environmental economics. Cambridge: Blackwell, 1995. p.3-25.

VEDELD, P.O. The environment and interdisciplinarity ecological and neoclassical economical approaches to the use of natural resources. Ecological Economics, v.10, n.1, p.1-13, May 1994.

VIANA, V.M.; MENDES, J.C.T. Recuperação da cobertura florestal da bacia do rio Corumbataí. In: SEMINÁRIO DE RECUPERAÇÃO FLORESTAL E DESENVOLVIMENTO SUSTENTÁVEL NA BACIA DO RIO CORUMBATAÍ, 2. Piracicaba: SEDEMA, 1998. p.8-13.

WHITE, P.C.L.; LOVETT, J.C. Public preferences and willingness-to-pay for nature coservation in the North York Moors National Park, UK. Journal of Environmentai Mianagement, v.55, n.1, p.1-13, Jan. 1999. 
132.

WHITEHEAD, J.C. Willingness to pay for quality improvements: comparative statics and interpretation of contingent valuation results. Land Economics, v.71, n.2, p.207-215, May 1995.

WHITEHEAD, J.C.; HAAB, T.C.; HUANG, J.C. Part-whole bias in contingent valuation: will scope effects be detected with inexpensive survey methods? Southern Economic Journal, v.65, n.1, p.160-168, Jul. 1998.

WHITTINGTON, D. et al. Giving respondents time to think in contingent valuation studies: a developing country application. Journal of Environmental Economics and Management, v.22, n.3, p.205-225, May 1992. WILLIG, R.D. Consumer's surplus without apology. American Economic Review, v.68, n.4, p.589-597, Sep. 1976.

WINPENNY, J.T. Values of environment. 2.ed. London: HMSO. Overseas Development Institute, 1993. 277p.

WUREN, W.V.; ROY, P. Private and social returns from wetland preservation versus those from wetland conversion to agriculture. Ecological Economics, v.8, n.3, p.289-305, Dec. 1993. 
APÊNDICE 1. Croqui de localização, abrangência e hidrografia da bacia do rio Corumbatai (sem escala).

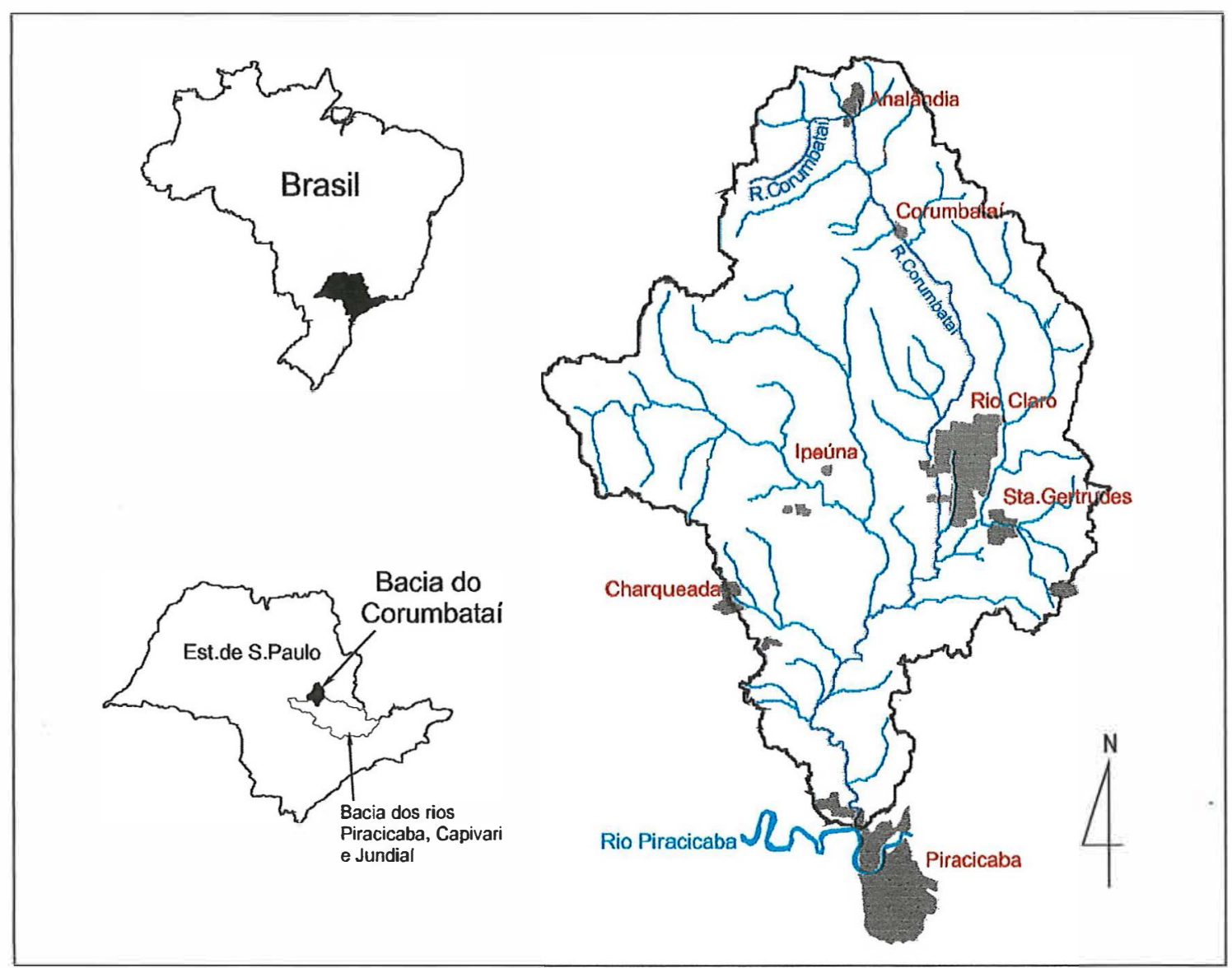

Fonte: reprodução sobre originais de Koffler (1993) e São Paulo (1999). 
APÊNDICE 2. Uso do solo na bacia do rio Corumbataí.

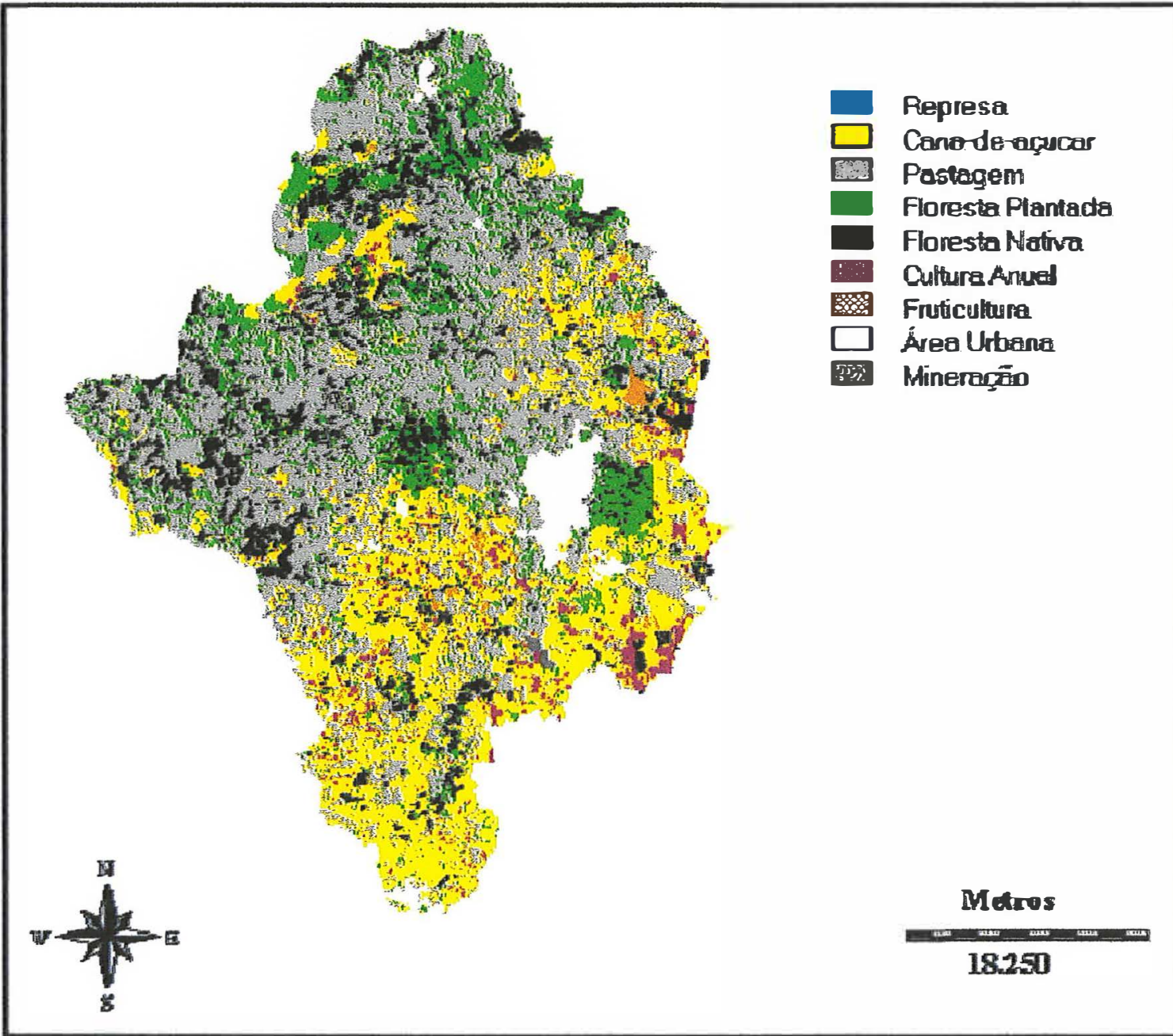

Fonte: cortesia do Prof. Carlos Alberto Vetorazzi (Depto. de Engenharia Rural ESALQ/USP), com cores da legenda alteradas. 
APÊNDICE 3. Material de apoio e questionário para as entrevistas ${ }^{24}$.

\section{Universidade Federal de São Carlos CENTRO DE CIÉNCIAS AGRÁRIAS \\ Depto. Tecnologia Agroindustrial e Sócio-economia Rural}

Valor atribuído pela população às matas ciliares da bacia do rio Corumbataí, SP - fase 2

ROTEIRO DE ENTREVISTA

1. SORTEAR UM NÚMERO (1 A 5) E CHECAR OS VALORES DA TABELA

2. PREENCHER OS CAMPOS DE UM FORMULÁRIO COM:

Valor inicial - Valor maior - Valor menor (item 2 do questionário)

\section{ABORDAR A PESSOA A SER ENTREVISTADA CONFORME COMBINADO}

Nós estamos fazendo uma pesquisa para uma tese de doutorado na ESALQ, a escola de Agronomia de Piracicaba, e estamos interessados na sua opinião sobre um assunto que já Ihe vou explicar.

O Sr.(Sra.) tem alguns minutos para conversarmos?

4. ANOTAR NN DE "NÃO" (UM “X” EM CADA QUADRADINHO):

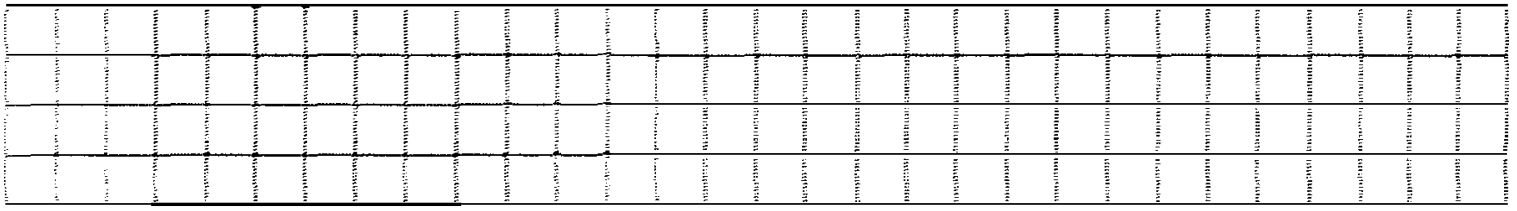

5. SE A RESPOSTA FOI "NÃO", VOLTAR PARA O ITEM 3. SE "SIM", PROSSEGUIR:

Todas as informações que o $\mathrm{Sr}$.(Sra.) nos der vão ficar em segredo. Eu não vou perguntar o seu nome, nem seu endereço e nem o seu telefone. Apenas a cidade e o bairro em que o Sr.(Sra.) mora.

\section{ANOTAR CIDADE E BAIRRO}

As mesmas perguntas que vou Ihe fazer estão sendo feitas para muitas outras pessoas daqui e de cidades vizinhas.

\section{EXPLICAR O ASSUNTO COM APOIO DA FOTO}

O assunto é o seguinte. Quase toda a água que nós usamos aqui na região de Piracicaba, Rio Claro e outras cidades vizinhas vem dos rios que formam o Corumbataí e do próprio rio Corumbataí. A qualidade da água é prejudicada pelo esgoto, pelo despejo das

24 Tamanho das fontes de caracteres e da figura reduzido em relação aos originais em função do tamanho da folha de papel utilizado na pesquisa. 
fábricas e pelo lixo jogado por aí. Algumas prefeituras estão tentando resolver uma parte do problema com estações de tratamento de esgoto.

Um outro problema é quando chove, nas terras de lavoura. A enxurrada arrasta terra, ciscos e restos de adubo e de venenos usados nas lavouras. Se tem mata na beira do rio, uma parte da sujeira fica presa entre as plantas ou penetra no chão e diminui a sujeira que vai para a água. Além disso, tendo a mata, continuam existindo ánores e outras plantas que estão desaparecendo de nossa região. A mata serve de lugar de criação e alimentação de animais e passarinhos. As frutas, sementes e bichinhos que caem das árvores servem de alimento para os peixes.

Se a enxurrada tem "caminho livre", toda essa sujeira vai para os rios e complica o tratamento da água para consumo nas cidades, além de deixar o rio mais raso e aumentar o risco de enchentes.

A lei obriga que tenha pelo menos 30 metros de mata de cada lado do rio, mas na maioria dos lugares não tem, porque a mata foi derrubada, às vezes há muito tempo. Alguns agricultores derrubaram a mata na beira do rio para fazer lavoura ou pasto. Mas muitas pessoas compraram seu sítio ou sua fazenda já sem a mata.

Para diminuir este problema, o correto seria plantar mais matas na beira dos rios. Mas isso custa caro e vai ser preciso usar terras de sítios e fazendas que hoje estão ocupadas com lavouras e pasto. Isto pode representar prejuizo para os agricultores. Se não podem mais plantar na beirada dos rios, vai diminuir o seu ganho, além da obrigação de cuidar da mata plantada. Essa mata não pode ser cortada para venda de madeira.

Para resumir: as matas na beira dos rios têm vantagens e desvantagens. As vantagens são melhorar a qualidade da água, proteger os barrancos do rio, melhorar a paisagem, servir de lugar de criação e morada de animais e passarinhos e aumentar a quantidade de peixes. Como o Sr. (Sra.) viu na foto, hoje tem muito menos mata do que é necessário.

Mas tem uma complicação: para aumentar a quantidade, as matas terão que ser plantadas em terras de agricultores, que terão menos terra para o plantio de lavouras e assim terão seu ganho diminuído. O aumento da quantidade de matas contribui, mas não resolve todo o problema sobre o qual nós conversamos até aqui.

Está sendo discutido um projeto de plantio de matas na beira dos rios que formam o Corumbataí. As matas plantadas serão cuidadas até que estejam formadas.

Para pagar as despesas do plantio e de cuidar das árvores, há uma proposta de aumentar um pouco a conta de água das residências. De acordo com o total que a população está disposta a pagar, será possivel plantar mais ou menos matas na beira dos rios.

O dinheiro arrecadado será repassado às prefeituras, de acordo com a quantidade de mata a ser plantada em cada município, que ficarão responsáveis pelo plantio das árvores nas margens de todos os rios que formam o Corumbatai.

O Sr.(Sra.) entendeu?

\section{ANOTAR SE ENTENDEU O PROBLEMA OU NÃO.}

9. SE NÃO ENTENDEU, EXPLICAR APENAS MAIS UMA VEZ.

10. FAZER AS PERGUNTAS DO FORMULÁRIO.

11. IDENTIFICAR O PRÓXIMO ENTREVISTADO. 
137.

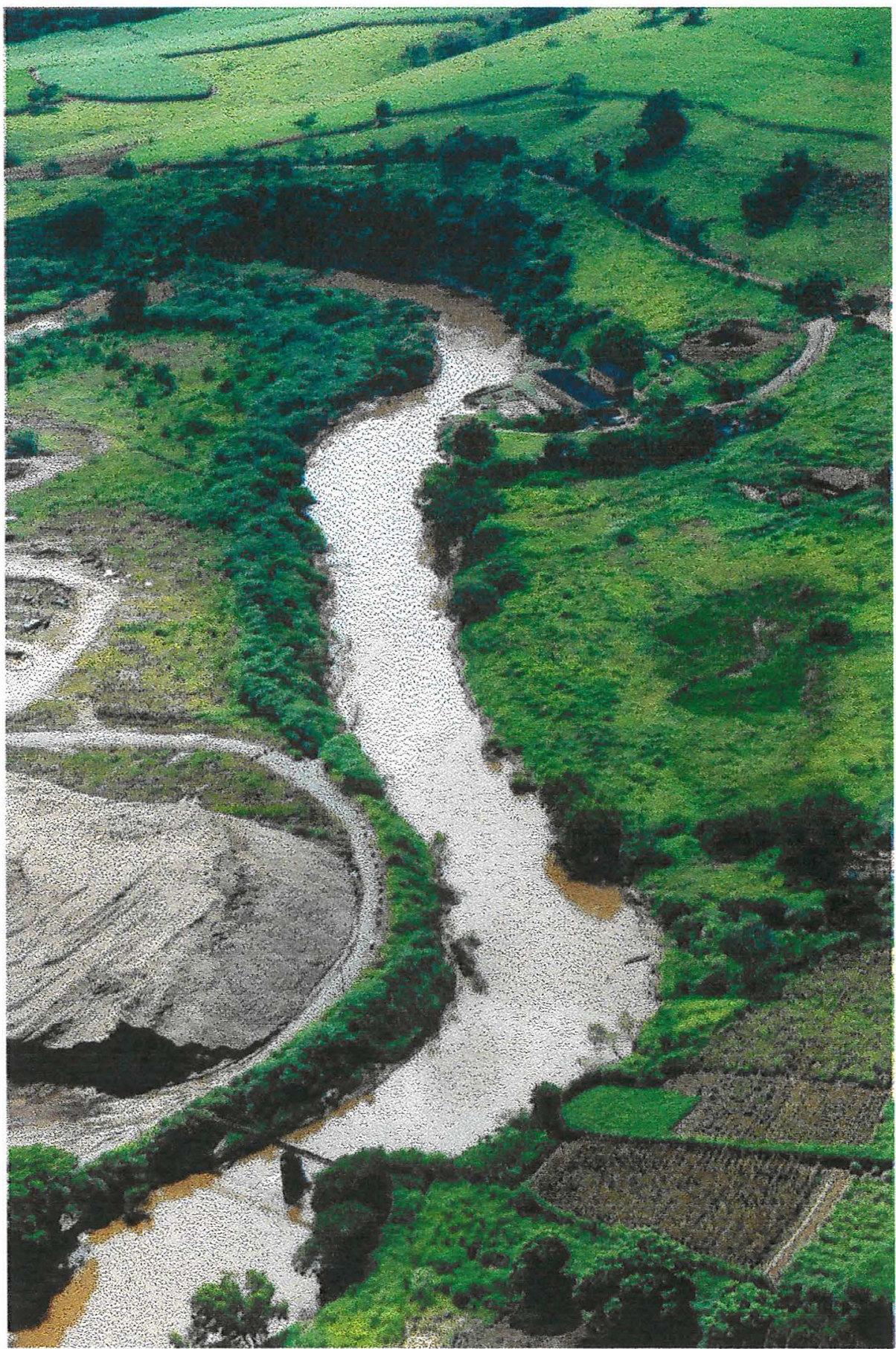

Fonte: cortesia SEMAE. Serviço Municipal de Água e Esgoto de Piracicaba. (Foto: Christiano DiehI Neto, jun./1999). 
Valor atribuido pela população às matas ciliares da bacia do rio Corumbatai, SP - fase 2 RESIDENCLA DO ENTREMSTADO:

\begin{tabular}{|c|c|c|}
\hline & & \\
\hline MUNICIPIO & BARRO & \\
\hline
\end{tabular}

APÓS AS EXPLICAÇÕES DO "ROTEIRO”:
1. Entendeu o problema?
$1 . \mathrm{SIM}$
O. NÃO

SE "NÃO", EXPLICAR SÓ MAIS UMA VEZ (RESUMO) E FAZER A PERGUNTA SEGUINTE:

$\odot$ 2. OSr. (Sra.) concorda que sua família pague $R \$$ a mais por mês na conta de água, durarte dez anos?

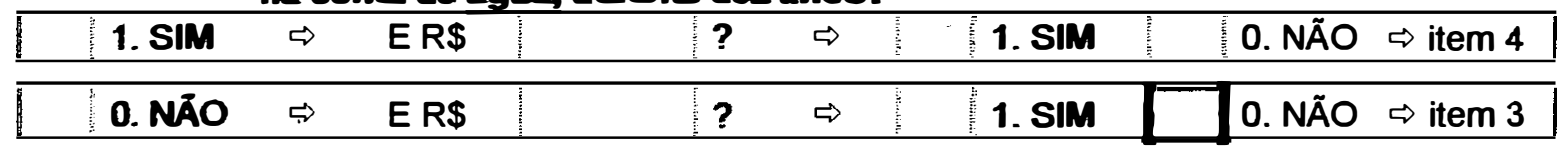

NO CASO DE "NÃO" E "NÃO":

乃 item 4

3. Há algum motivo especial por que o Sr. (Sra.) não concorda em pagar?

ANOTAR O TIEM QUE MEUHOR SE APROXIMA DA RESPOSTA:
$\square$
1. O valor é muito alto
2. O problema é do governo
3. O problema é dos agricultores
4. Nâo confio no uso dos recursos
9. Outros:
5. NẼo acho o assunto importante
6. Preciso de mais tempo para pensar
7. O projeto vai me dar prejuizo
8. لé pago muitos impostos e taras

4. Só mais umas perguntas:

- Qual a sua idade?

- O Sr.(Sra.) estudou quantos anos?

- Quanto é a renda de sua família, por mês?

- Quantas pessoas moram na sua casa?

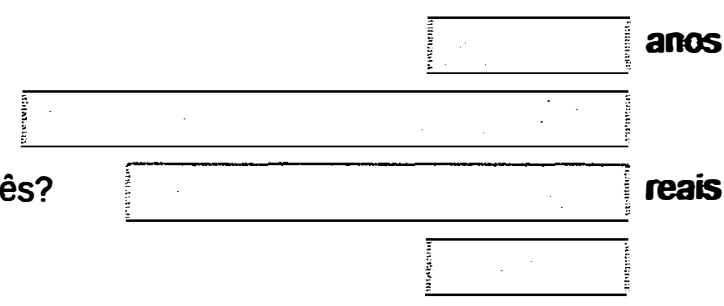

- A principal renda de sua família vem de que tipo de ocupação?

1. AGRICULTURA 2. INDÚSTRIA 3. SERMLOOS

4. AFOSEMTNDORA

- MUITO OBRIGADO POR SUA COLABORAÇÃO.

- Anotar

LOCAL
SEXO

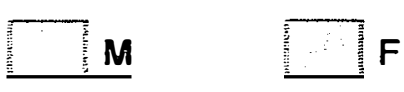

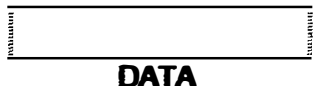

DATA
ENTREVSTADOR 


\section{VALORES PROPOSTOS AO ENTREVISTADO}

Valor atribuído pela populaçâo às matas ciliares da bacia do rio Corumbataí, SP - fase 2

\begin{tabular}{|c|c|c|c|}
\hline $\begin{array}{c}\text { SORTEAR } \\
\downarrow\end{array}$ & $\begin{array}{c}\text { VALOR INICIAL } \\
\downarrow\end{array}$ & $\begin{array}{c}\text { VALOR MAIOR } \\
\downarrow\end{array}$ & $\begin{array}{c}\text { VALOR MENOR } \\
\downarrow\end{array}$ \\
\hline 1 & 0,50 & 1,00 & 0,10 \\
\hline 2 & 2,00 & 3,00 & 1,00 \\
\hline 3 & 5,00 & 7,00 & 3,00 \\
\hline 4 & 10,00 & 15,00 & 7,00 \\
\hline 5 & 30,00 & 50,00 & 15,00 \\
\hline
\end{tabular}




\section{APÊNDICE 4. Das vicissitudes por que pode passar uma pesquisa.}

Consumidores piracicabanos denunctaram aos srvico Municipal de Água e Esgoto (Stmae) de Pirm. cicaba que existea pessods usando u nome da atuarqua part simular pesquisa na cidade sobre possivel cobrança de taxa - aproximada. mente $\mathrm{k} \$ 1,00$ - para ser emprega. da pelo seinate no reflorestamentro la mata ciliar de rós e ribeiróes da cidade.

Ac) receber una denúncia de un inorador do Piracicamirim, o vereador Moacir Monteiro eneamnhou doxumento ao Semae solicitou informaçios sobre o assunto.

"Vão temos ligaça nenhuma com essas pessuas avisa a asses. soria de imprensa da autarquia, afirmando desconhecer tais pesquisudores, gue nà puclerant ser localizados $A$ autarquia recebeu cerca de 10 denúncias de pessoas que nào quiseram se identificis, mas tockes afirmaran que năo chegaram a pagar a taxa" aos pescuisaderes

O Sentac possui um projeto de reflorestamento para recuperara neta ciliar do rio Conentataí, junto. com o lnstruto de Pesquisa e Estu dos Blorestais (IPET) da Escula Superior de Agriculura Liz de Queiroz (ESALQHSF) Segundo losé Edgard Camolese presidente da autarqua, esse projeto năo realiza tose tipo de pesquisa ou mesmo de arrecadação "O dinheiro investido no projeto, como ja foi divulgado pela imprensa, é proveniente da arrecadação do Semae, sena nenhuma cobranca extra". compleatenta.

"O IPEF nás esta realizandu nenhuma pesquisa desse tipo". informou o engenheiro toào Carles Teixeira Mendes coordenador tecnico do projeto Conumbatá peto IPEP.

De acordo com a assessuria do semate, oconsumida que for abordado pelos pesquisadores devera comunicar-se imediatanente com a Policia, pelo 190 , ou con a centall de Atendimento ao Consum dor da autarquia através do relefone 195, planta 24 hords, inclusive finais de semana e feriados. 
Subject: Re: Reclamação s/notícia

Date: Tue, 24 Nov 2099 14:04:31 -0200

From: "Joacir Cury" <joacirejpnet.com.br>

To: "Caetano Brugnaro" <brugnaroeimagenet.com.br>

Prezado Brugnaro.

A denúncia sobre a pesquisa, publicada no JP, é do Semae Serviço Municipal de Água e Esgoto. Não existe equívoco na noticia, o que faltava era descobrir se existia alguma pesquisa na cidade nessa linha. Existe, você está informando, séria, não envolve o Semae, não cobra nada, é outra história.

Vamos esclarecê-la. A jornalista Angela Buscariolo vai contactá-lo, por telefone, ainda hoje.

Joacir Cury

$>$ De: Caetano Brugnaro <brugnarodimagenet.com.br>

$>$ Para: joacirejpnet.com.br

$>$ Assunto: Reclamação s/notícia

> Data: Quarta-feira, 24 de Novembro de 1999 10:46

$>$

$>$ Piracicaba, 24 de novembro de 1999.

$>$

$>$ Ao Jornal de Piracicaba

$>$ A/C Dr. Joacir A. Cury

$>$

$>$ Senhor Editor:

$>$

$>$ O Jornal de Piracicaba de hoje, 24/11/1999, traz, à pág.A-7, um "alerta" sobre "falsos pesquisadores" que estariam propondo a cobrança de uma taxa de R\$ 1,00 para reflorestar as margens dos rios da região. Se for o que estou pensando, a notícia, não importa de onde tenha partido, é um tremendo equívoco e um alarme falso e irresponsável.

$>$ Estou coordenando uma pesquisa que tem por objetivo avaliar a reação da população a uma nova taxa, hipotética, no caso sobre a conta de água, para um também hipotético projeto ambiental. A pesquisa está sendo feita em Piracicaba e mais seis cidades da região. 
$>$ A primeira informação que a pessoa convidada para a entrevista recebe é que se trata de uma pesquisa para uma tese de doutorado na ESALQ. A suspeita de que alguém possa ter "cobrado" algum valor de algum cidadão é puro delírio. Os entrevistadores são alunos do curso de Engenharia Agronômica da UFSCar, campus de Araras, cuidadosamente selecionados e capacitados, e apresentam-se devidamente identificados por crachás em que constam o logotipo e o nome da Universidade, o nome do aluno, meu nome como coordenador do projeto e números de telefone através dos quais é possível me localizar a qualquer hora do dia ou da noite.

$>$ Portanto, se o alarme desse jornal e o projeto a que me referi são a mesma coisa, "falsos pesquisadores" é um imputação leviana e, da forma como foi colocado o assunto, pode até levar meus colaboradores a enfrentar constrangimentos totalmente indevidos.

$>$ Solicito desse jornal o imediato esclarecimento a seus leitores, entre os quais me incluo, do mal-entendido que provocou ou a que foi induzido. $>$

$>$ Prof. Caetano Brugnaro

>Universidade Federal de São Carlos - campus de Araras

>Centro de Ciências Agrárias - Fone: 0xx19 - 542-3800

>Residência: R.Dona Virgínia Zaia, 329 - Paulista

$>$ CEP 13424-030 Piracicaba SP

>Fone: 0xx19 - 433-6832

>e-mail: brugnarodimagenet.com.br ou brugnarodcca.ufscar.br $>$

$>$ 
Gin matéria publicada contens Opelo IP o Servico Municipal de Agua e Esguto tiemae) alenala a propulacia scitire a aça de k'squisader que nảo possuem nenhum vínculo con a autat yuia, mas estariam usando ono me dela para realizar pesyuisa stobre a possivel cobrança de uma taxa cle aproximadamente K\$ 1,00. pata ser empregada pelo semat. no retlorestamento da Inata ciliar de rios e pibeiroes da c idade. As denúncias as semate. feitas pror telefune, partiran de cerca de 10 consumidores piracicabanos. que nà quiseram se ulentificar.

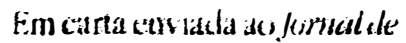
l'iracicaba. o protessor Cactano Brugnaro, do Centro de Ciencias Agsarias da liniversiclade federal Jésào Carlos - campus de Araras, letitor do IP. afirma ser 0 coordenador de una pesquita que tem por objetivo avaliar a reaçáo da populaçáo sobse a cobrança de uma nova tasi, -hipo. tetica", sobre a conta de agua, para um também hipotético projetu ambiental". "A pesquisa ć para uma tese de doutorado es: cá sendo feita em Piracicaba cem mas seis ridades da regiano" afir. ina cle em sua correspondencta.

- Os entrevistadores saolalunow do curso de Engedhatia Agronómica da UFSCar, campus de Arams cuidadosanente sele cionados e capaciados e anre sentam-se devidamente identiff cados por crachás em que cons: tam o logotipo e o nome da thilersidade, o nome do aluno, ineu nome como cooordenador doprojeto enaniers letelefone através dos quais é possivel me lvalizar a qualquer hora do die uda noite escreveu Brugnaro. Como foi afirmado potosassesooria de lappensa do Semae. na matéria de ontem, a autatquia desconhecia tais pesquisadores. que náo puderam ser loeatizados, poís nentum dos denunciantes soube identifica-los. 


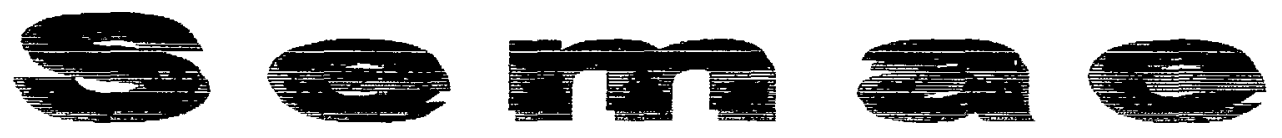

Serviço Municipal de Água e Esgoto de Piracicaba - Rua 15 de novembro, 2200 Tel/Fax $019430-9605$

\section{a응}

$26 / 11 / 99$

Prezado Professor

Caetano Brugnaro,

Recebi sua gentil carta (via Internet). Assim como o senhor defende o nome de uma organização, também tenho por obrigação defender 0 nome da organização à qual presido desde 1993;

Face ao exposto, temos a esclarecer:

\section{Denúncia}

Esta não é a primeira vez, nem será a última que recebemos reclamações de consumidores que se sentiram enganados por falsos servidores desta autarquia. Reclamações estas procedentes, desta vez, da Central de Atendimento ao Consumidor (fone 195 - Semae) e da Câmara de Vereadores de Piracicaba, onde o vereador Moacir Nazareno Monteiro pede explicações (através de requerimento no. 823/99 de 08 de novembro de 1999), ao Semae sobre possiveis pesquisadores falsários na cidade.

\section{O requerimento}

$O$ requerimento diz o seguinte: 
145.

"Algumas pessoas nos solicitaram informações sobre uma pesquisa, que dizem ser realizada pelo Serviço Municipal de Água e Esgoto, procurando saber se o munícipe aprovaria o pagamento de pequena contribuição, aproximadamente $\mathrm{R} \$ 1,00$ (um real), cujo montante seria empregado no reflorestamento das margens de nossos ribeirões e rios.

Para evitar que pessoas procurem os lares dos piracicabanos, usando o nome do Semae, a fim de obterem respostas que satisfaçam seus interesses e, como uma consulta dessa natureza poderia ser do conhecimento público, mesmo por que $\circ$ resultado talvez proporcionasse respostas mais esclarecedoras, necessário se faz alguns esclarecimentos;

Requeremos nos termos regimentais, que se oficie ao chefe do Executivo, para que através do órgão competente, responda às seguintes indagações:

1 - Procedem as afirmativas de que o Semae vem realizando essa pesquisa?

2 - Em caso positivo, a pesquisa vem sendo realizada em toda a cidade?

3 - Outras informações.

\section{Ciência sobre o projeto}

Assim sendo, em momento algum tive ciência que tal projeto seria realizado em nome da autarquia, conforme está mencionado no requerimento do prezado vereador;

\section{Polícia}

Sim, sempre que o consumidor tiver dúvidas e perceber que pessoas estão se utilizando do nome da Autarquia ou tentando passar algum golpe, recomendamos chamar a polícia - mas, jamais para atuar estudantes em trabalho de pesquisa, - como o senhor afirma - e sim, para coibir a ação de falsários.

Por isso, defendemos que que pesquisas como esta sejam amplamente divulgadas, antes, durante e depois da obtenção de resultados; 
146.

\section{Profissionalismo}

Aqui em nossa autarquia há controle de tudo o que é produzido por nossa Assessoria de Imprensa e em nenhum momento, nem o Assessor de Imprensa, nem os demais membros da equipe deixam de me comunicar sobre o que deve ou não ser enviado ao veículos de comunicação. Esteja eu em São Paulo, ou em qualquer outra cidade do país ou do exterior.

Confio no profissionalismo dos meus assessores, afinal foram escolhidos pelo histórico de competência e responsabilidade que possuem.

\section{Retorno}

Terei muito prazer em recebê-lo aqui para que sejam apresentados os resultados da pesquisa, a qual fazemos questão que seja divulgada na mídia local, pois é do interesse de todos nós.

Atenciosamente, 